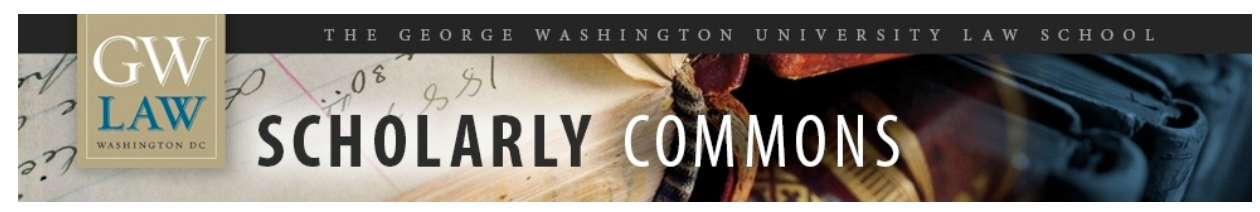

GW Law Faculty Publications \& Other Works

Faculty Scholarship

2010

\title{
Copyright and the World's Most Popular Song
}

Robert Brauneis

The George Washington University Law School, rbraun@law.gwu.edu

Follow this and additional works at: https://scholarship.law.gwu.edu/faculty_publications

Part of the Law Commons

\section{Recommended Citation}

Brauneis, Robert, "Copyright and the World's Most Popular Song" (2010). GW Law Faculty Publications \& Other Works. 260.

https://scholarship.law.gwu.edu/faculty_publications/260

This Article is brought to you for free and open access by the Faculty Scholarship at Scholarly Commons. It has been accepted for inclusion in GW Law Faculty Publications \& Other Works by an authorized administrator of Scholarly Commons. For more information, please contact spagel@law.gwu.edu. 


\section{Copyright and the World's Most Popular Song}

\section{Table of Contents}

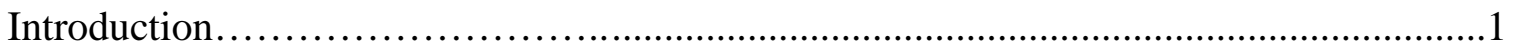

I. "Good Morning to All”: An Appreciative History ............................................4

II. The Emergence and Triumph of "Happy Birthday to You” .............................15

III. The Copyright Status of "Happy Birthday to You” ........................................22

A. Some Necessary Analytical Framework ............................................23

1. Derivative Works ...........................................................23

2. Copyright Under the 1909 Act...........................................24

B. The Original Term: The 1935 Publications ..........................................25

1. Authorization and Authorship...........................................26

a. The Myth of a Court Ruling ..........................................28

b. Evidence of Authorship................................................29

i. The Patty Smith and Jessica Hill Depositions............29

ii. Earlier Published Versions .........................................31

iii. The 1934-35 Registrations and Publications..............33

iv. Later Published Versions...........................................36

v. Statements in the Hill Foundation Complaints............37

vi. Popular Accounts of Authorship ...............................38

vii. A Summary .............................................................40

2. Publication with Notice.....................................................40

C. The Renewal Term...................................................................44

1. Summy-Birchard's Eligibility to Apply for Renewal................45

2. The Sufficiency of the Renewal Applications ...........................48

D. Epilogue: Copyright and Ownership During the Renewal Term.............55

IV. Lessons From The History Of "Happy Birthday to You”.................................57

A. The Risks of Anecdotes .......................................................................58

B. Barriers to Challenging Copyright Validity …......................................59

C. The Effects of Copyright Owners' Failure to Enforce............................62

D. Recordkeeping and Tracking in the Copyright Office..........................65

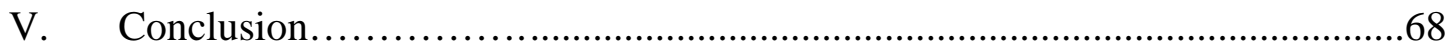




\section{Copyright and the World's Most Popular Song}

\section{Robert Brauneis*}

When Justice Breyer protested Congress's 20-year extension of the term of copyright in his dissent in Eldred $v$. Ashcroft, ${ }^{1}$ he chose one song to emphasize what was to his mind the already overly generous protection of copyright law: "Happy Birthday to You (melody first published in 1893, song copyrighted after litigation in 1935), [the copyright of which is] still in effect and currently owned by a subsidiary of AOL Time Warner." 2 The example, even in that brief form, is a powerful one. "Happy Birthday to You" is a simple song that most people have learned by hearing it performed by family and friends, and many probably assume that it is not under copyright at all. 1893 is a long time ago - 106 years before Eldred was decided. And, for those who are unsympathetic to and suspicious of large corporations, AOL Time Warner - now just Time Warner - is one of the largest media and entertainment companies in the world. ${ }^{3}$

The newspaper article to which Justice Breyer cited, and others like it, recite a standard "Happy Birthday to You" anecdote that just seems to make the example more powerful. "Happy Birthday to You” started out life as "Good Morning to All," a song with the same melody but different words, "written as a classroom greeting by two . . . teachers . . . who were sisters," ${ }^{4}$ namely, Mildred and Patty Hill. This adds some element of authorship - the song is not just a folk song - but it suggests that the authors were not professionals, and more or less stumbled across the song while teaching, as it turns out,

\footnotetext{
* Associate Professor of Law and Co-Director of the Intellectual Property Law Program, The George Washington University Law School; Member, Managing Board, Munich Intellectual Property Law Center. I am indebted to a very large number of people who have selflessly aided me in researching and writing this article. For assistance with historical research, I would like to thank Ms. Kat Caverly of Kat Caverly Enterprises, Inc.; Ms. Emily G. Blaising of the Southwestern Baptist Theological Seminary; Mr. Gregory J. Plunges and Ms. Trina Yeckley of the New York City office of the National Archives and Records Administration, Northeast Region; the staff of the Chicago office of the National Archives and Records Administration, Great Lakes Region; William and Geraldine Brauneis (my parents, who aided me greatly with research in Chicago, where they live, and Louisville, and who undoubtedly first introduced me to "Happy Birthday to You" on my first birthday); Mr. Allen Foresta and Ms. Jennifer Govan of the Gottesman Libraries, Teachers College, Columbia University; Ms. Arlene Massimino and Ms. Susan Tell of the New York County Surrogate's Court; Mr. James Holmberg of the Filson Historical Society, Louisville, Kentucky; Mr. Bruce Tabb and Ms. Linda J. Long of the Special Collections and University Archives Division of the University of Oregon Libraries; Prof. Michael Raley of Northeastern Illinois University; and Prof. Bruce Smith of the University of Illinois. For comments on drafts of the article, I would like to thank Roger Schechter, Robert Tuttle, Naomi Cahn, Alan Kress, Zvi Rosen, Robert Kasunic, Fred Lawrence, and Ralph Oman. For comments on the section of the article concerning Copyright Office recordkeeping procedures, I would like to thank David O. Carson.

${ }^{1} 537$ U.S. 186 (2003).

${ }^{2}$ Id. at 262 (Breyer, J., dissenting) (emphasis in original).

${ }^{3}$ Time Warner has in the meantime spun off its music publishing and recording business to the Warner Music Group, see infra p, xxx, but this would not likely comfort those who don't like large companies, since the Warner Music Group is still a very large company.

4 “Profitable ‘Happy Birthday,"” Times of London, Aug. 5, 2000, p. 6
} 
kindergarten. ${ }^{5}$ Moreover, many have suggested that, notwithstanding the attribution of the song to the Hill sisters, it is so much like other previous songs that it should be treated as having arisen from a folk tradition rather than the creative talents of a particular author. ${ }^{6}$ "Happy Birthday to You" is not only currently under copyright, but will supposedly be under copyright until the year 2030 - 137 years after 1893, an incredibly long time even by the standards of the Copyright Term Extension Act that Justice Breyer concluded was unconstitutional. ${ }^{7}$ Thus fortified, the "Happy Birthday to You" anecdote has become a standard arrow in the quiver of those who feel copyright protection as gone too far, from Kembrew McLeod ${ }^{8}$ to Lawrence Lessig ${ }^{9}$

Is it possible to check the accuracy of this standard anecdote? It turns out that there are a number of rich sources of material on the history of the song that have remained largely untapped. These include filings in four federal court cases in the 1930s and 1940s involving "Good Morning to All"; filings in litigation over the management of a trust that owned the right to receive royalties from the song from 1942 to 1992; unpublished papers of and about Patty Hill at the Filson Historical Society in Louisville, Kentucky and at the Gottesmann Libraries at Teachers College, Columbia University; probate court records in Louisville and in Chicago, Illinois, where a brother of the Hill sisters died; transcription notebooks of Mildred Hill at the University of Oregon Libraries; and registration records and recorded transfers in the United States Copyright Office. Because many of these documents are not otherwise easily accessed, over a hundred of them have been published on the website of the Jacob Burns Law Library at The George Washington University Law School in conjunction with this article. ${ }^{10}$

Those documents, along with many other historical sources, reveal a history that is much more rich and complicated than the standard anecdote suggests. The true story of the song does not provide simple anecdotal fodder for either opponents or proponents of strong, long copyright. On the one hand, "Good Morning to All" was not a lark of amateurs. Rather, it was the product of a highly focused, laborious effort to write a song that was extremely simple to sing, yet musically interesting and emotionally expressive, undertaken by a composer and an educator who happened to be sisters. Those sisters, Mildred and Patty Hill, were well aware of copyright law, and took steps to ensure that copyright in the song would be preserved. On the other hand, it is doubtful that "Happy Birthday to You," the famous offspring of "Good Morning to All," is really still under copyright.

\footnotetext{
${ }^{5}$ See, e.g., Hermine Williams, "Women as Songwriters," in Marvin E. Payner, ed., Facts Behind the Songs: A Handbook of American Popular Music from the Nineties to '90s 310, 311 (1993) (calling Patty and Mildred Hill "sisters and kindergarten teachers").

${ }^{6}$ See sources cited in footnote 42, infra.

${ }^{7}$ See infra p. xxx (discussing the duration of the copyright currently claimed for the song).

${ }^{8}$ See Kembrew McLeod, Freedom of Expression ${ }^{\circledR}$ : Overzealous Copyright Bozos and Other Enemies of Creativity 16 (2005).

${ }^{9}$ See, e.g., http://www.wired.com/wired/archive/13.07/posts.html?pg=7

${ }^{10}$ The documents have been temporarily posted at http://docs.law.gwu.edu/facweb/rbrauneis/happybirthday.htm. References to the documents in this draft are made by means of a series of letters and a number in brackets, e.g., "[WWH 22]," which are references to index numbers on the web page that lists and links to the documents.
} 
The claim that "Happy Birthday to You" is still under copyright has three principal weaknesses. Most significantly, there is a good argument that copyright in the song has never been renewed. Under applicable law, the original term of copyright in the song ended in 1963. If no renewal application was timely filed, the song would have entered the public domain at that time. The only renewals filed were for particular arrangements of the song - piano accompaniments and additional lyrics that are not in common use. It is unlikely that these renewals suffice to preserve copyright in the song itself. Second, the first authorized publication of "Happy Birthday to You," in 1935, bore a copyright notice that was almost certainly not in the name of the owner of copyright in the song. Under the law in force at the time, publication with notice under the wrong name resulted in forfeiture of copyright protection. Third, the current putative owner of copyright in "Happy Birthday to You," the Summy-Birchard Company (a wholly owned subsidiary of Warner/Chappell Music, Inc.), can only claim ownership if it can trace its title back to the author or authors of the song. Yet it appears that the only possible authors to whom it can trace title are Mildred and Patty Hill themselves, and there is scant evidence that either of them wrote the song. (There is plenty of evidence that they wrote the song "Good Morning to All,” but that song had different lyrics.)

There may be many lessons that can be learned from the true history of "Happy Birthday to You," but this article concentrates on four. The first concerns the perils of using anecdotes in legal and policy arguments. If "Happy Birthday to You” was a real creative achievement, and at the same time is likely no longer under copyright, then it is not a good example of the overextension of copyright. ${ }^{11}$ Use of an anecdote without investigation of whether the assumptions that make it powerful are true, or of whether the case described by the anecdote is typical, may end up distorting discussions of difficult policy choices.

Because the histories of particular copyrighted works may or may not be typical, it would be a mistake to draw further general lessons for copyright policy from the history of "Happy Birthday to You," even if that history has been fully explored and all mistaken assumptions have been corrected. However, the song's true history does raise at least three concerns, which may be important issues of copyright policy if the song is

\footnotetext{
${ }^{11}$ Some might argue that a detailed inquiry into the actual copyright status of the song is of limited value, since the standard anecdote remains powerful so long as the song, if still under copyright, would benefit from a longer term than the law offered at the time it was composed, or so long as it would still be under copyright if current copyright term rules had been in place when it was composed. As for the first alternative, if "Happy Birthday to You" is still under copyright, then it is definitely benefiting from the retroactive extension of copyright term, a highly dubious matter under an incentive theory of copyright. In that respect, however, it is no different than hundreds of thousands of other songs. As for the second alternative, since under current rules the lifespan of the author figures into copyright term calculation, one would have to know who the author of the song was, which turns out not to be an easy matter with respect to "Happy Birthday to You." The Summy-Birchard Company, which now claims copyright ownership in the song, asserts that the song was jointly written by Mildred and Patty Hill. Under the rules applicable to works currently being created, that would mean that the song would be under copyright until 2016, 70 years after Patty Hill, the longer lived of the sisters, died in 1946. Summy-Birchard, however, claims that the song is actually under copyright until 2030 -- fourteen years longer than it would be under current rules -an oddity that is worth investigating.
} 
not an outlier in relevant respects. The first concern is raised by the lack of any litigation challenging the weaknesses in the song's copyright, even though the amount of revenues at stake (now probably about \$2 million per year) would ordinarily make such litigation worthwhile. The absence of such challenges strongly suggests that there are structural barriers to mounting them, and those structural barriers are worth exploring.

The second concern is raised by the publication and open availability of unauthorized versions of "Happy Birthday to You" for a period of over twenty years, from before 1914 to 1934, without any enforcement action taken by the alleged copyright owners. Were "Happy Birthday to You" a piece of real property, its open, unopposed use over such a period could have resulted in the acquisition of prescriptive rights. Copyright law has never had any version of adverse possession or prescriptive easements, arguably because the limited term of copyright protection itself served the function of clearing title and balancing the interests of the inattentive owner and the productive user. However, the uninterrupted term of federal copyright protection has now dramatically increased, from 28 years, after which the owner had to take the affirmative step of renewal, to the life of the author plus 70 years, which can easily add up to 120 years or more. In light of that increase, it may be necessary to develop some doctrine to avoid the inefficiency and inequity that could result from reassertion of copyright in a work that had been published and used by others without opposition over a long period of time.

Lastly, whether or not prescriptive rights would be appropriate in the realm of copyright, it is clear that as copyright term lengthens, it will become more and more difficult to gather evidence relevant to determining the validity of contested copyrights. It is now possible for a work to still be under copyright long after not only the death of its author, but after the death of anyone who knew the author, which makes it very difficult to present testimony about the circumstances of the work's creation. There may be little that can be done about the problem of live testimony, but more could be done to preserve documentary evidence. Copyright Office correspondence, for example, is currently only preserved for about twenty years, and deposit copies of registered works are often discarded without even digitally scanning title pages or other appropriate excerpts.

Part I of this Article reviews the history of the composition of "Good Morning to All," and the background of its authors, Mildred and Patty Hill. Part II considers the public history of "Happy Birthday to You," including its development into the standard birthday song and the growth of the licensing program that now generates those \$2 million per year. Part III contains a detailed examination of the song's ownership and copyright history. Part IV considers the concerns raised by and lessons to be learned from the history of the song.

\section{I. “Good Morning to All”: An Appreciative History}

The story of "Happy Birthday to You” undoubtedly starts with Mildred Jane Hill and Patty Smith Hill, who were two of the six live-born children of the Reverend William 
Wallace Hill and his wife Martha Jane Smith. ${ }^{12}$ Reverend Hill's previous 14-year marriage to Mary B. Downing had ended with Mary's death in 1856; their infant twins had died in 1854. ${ }^{13}$ He and Miss Smith married two years later, when he was 43 years old and she was considerably younger. ${ }^{14}$ Mildred was their first child, born in 1859 . Patty was their fourth, born in early 1868 and not quite nine years younger than Mildred. ${ }^{15}$ The other Hill children - all of whom, as we will see, enter into the history of ownership of the copyright to "Happy Birthday to You" - were Mary Downing, born in 1864; William Wallace, born in 1866; ${ }^{16}$ Archibald Alexander, born in 1871; and Jessica Mateer, the youngest and most active in the copyright history of the song, born in $1874 .{ }^{17}$ Strikingly, although Reverend and Mrs. Hill had six children, they only had one grandchild. Archibald Alexander was the first of the Hill children to die, in $1908 ;{ }^{18}$ but he was also the only one to have any children of his own. His only child, Archibald Anderson Hill, was born in 1902, and became a renowned professor of linguistics, who in his later life was very involved with "Happy Birthday to You.",19

\footnotetext{
${ }^{12}$ One child was apparently stillborn. See [P2] (photograph of the gravestone of Willis Grimes Hill, born and died, January 26, 1863, Cave Hill Cemetery, Louisville, Kentucky). For the parents'names, see "Miss Jessica M. Hill,” (obituary) New York Times, July 26, 1951, p. 20; “Dr. Patty S. Hill of Columbia Dies,” New York Times, May 26, 1946, p.32; Centre College Alumni (1890), excerpt available at http://boards.rootsweb.com/localities.northam.usa.states.kentucky.bios/4995/mb.ashx.

${ }^{13}$ See Agnes Snyder, "Patty Smith Hill (1868-1946) Dynamic Leadership in New Directions," in Dauntless Women in Child Education 1856-1931, 233, 235 (1972); [P1] (photograph of gravestone of Martha Currie Hill and Samuel Alexander Hill, born and died, October 3, 1854, Cave Hill Cemetery, Louisville,

Kentucky).

${ }^{14}$ See Centre College Alumni (1890), supra note 3.

${ }^{15}$ According to The Encyclopedia of Louisville, Mildred Hill was born on June 27, 1859, and Patty Smith Hill was born on March 27, 1868. See Robert Bruce French, "Hill, Mildred Jane," in John Kleber, ed. in chief, The Encyclopedia of Louisville 386 (2001); Laurie A Birnsteel, "Hill, Patty Smith,” in John Kleber, ed. in chief, The Encyclopedia of Louisville 386-87 (2001). That birth date for Patty Smith Hill is consistent both with her age as reported on the 1880 U.S. Census (12), and her reported age as of her death on May 25, 1946 (78). See “Dr. Patty S. Hill of Columbia Dies," New York Times, May 26, 1946, p.32. On the other hand, Mildred Hill's age was reported on the 1880 census as 19, which is not consistent with an 1859 birth date.

${ }^{16}$ William Wallace Hill moved to Chicago and became a banker, co-founding the firm of Hill, Joiner \& Co. His partner, Theodore E. Joiner, was listed among the favored friends of Chicago utilities magnate Samuel Insull who were allowed to purchase shares of Insull Utility Investments at $\$ 12$ per share just before they were offered to the public at \$27 per share. See Time, Oct. 3, 1932.

${ }^{17}$ These years of birth are based on the reported ages of each Hill child on the 1880 U.S.Census, taken on June 2, 1880, and hence may be off by one year. In the case of Jessica M. Hill, her birth in late 1873 or early 1874 would be consistent with her reported age of 77 as of her death on July 25, 1951, see "Miss Jessica M. Hill,” (obituary) New York Times, July 26, 1951, p. 20; in the case of William Wallace Hill, his birth in late 1865 or early 1866 would be consistent with his reported age of 57 years as of his death on April 3, 1923. See Testimony of Corinne Dorothy Hill, In the matter of the estate of William Wallace Hill, deceased [WWH 3].

${ }^{18}$ See Edgar C. Polomé, "Archibald A. Hill: A Biographical Sketch,” in "Linguistic and Literary Studies in Honor of Archibald A. Hill Vol. I: General and Theoretical Linguistics" 13, ed. by Mohammed Ali Jazayery, Edgar C. Polomé, and Werner Winter (the Peter De Ridder Press 1976).

${ }^{19}$ See id.
} 
Reverend William Wallace Hill was a Presbyterian minister, educated at Princeton Theological Seminary, ${ }^{20}$ who during his long career served not only as a cleric, but as editor of a journal called the Presbyterian Herald, ${ }^{21}$ and as the president of three educational institutions: the Bellewood Female Seminary in Anchorage, Kentucky, which he founded, ${ }^{22}$ the Fulton Synodical Seminary in Fulton, Missouri; ${ }^{23}$ and Austin College in Sherman, Texas. ${ }^{24}$ In 1925, Patty Smith Hill recalled that her father encouraged and aided his daughters as well as his sons to get a good education and enter a profession. "While we were financially well-to-do in those days," said Patty, "my father believed that every girl should grow up with a profession. This was a radical philosophy everywhere fifty or sixty years ago, particularly in the South." 25 Mrs. Smith, herself an educated woman who had had the benefit of college tutoring, was also an important educational influence, and equipped the Hill house with an advanced playground, playroom, and workshop. $^{26}$ Reverend Hill died in 1878, when Mildred was eighteen, Patty ten, and the youngest of the Hill children, Jessica, only four, and the family entered a period of great material difficulties. $^{27}$

At the age of 19, Patty Hill began what turned out to be a long and distinguished career in early childhood education, which eventually led her to Teachers College at Columbia University, where she began as a lecturer in 1905 and retired as a full professor in $1935 .^{28}$ In September 1887, she entered the first class of the Louisville Training School for Kindergartners, founded and run by Miss Anna E. Bryan. Ms. Bryan founded the Training School in conjunction with several demonstration kindergartens run under the name of the Louisville Free Kindergarten Association. ${ }^{29}$ Bryan counted among her

20 Dr. Ilse DeForest, “Patty Smith Hill: A Biographical Sketch By One Of Her Students,” p. 10 (unpublished manuscript, on file at the Gottesman Libraries, Teachers College, Columbia University)

${ }^{21}$ Living Covenant, [the newsletter of the Anchorage, Kentucky Presbyterian Church], February 21, 1999, p. 9; id., March 14, 1999, p. 9, available online at http://www.anchoragepresbyterian.org/pgs1.htm

22 “Professor Patty S. Hill, Interview by Miss Chaffee, Summer, 1925,” p. 1 (unpublished manuscript on file at the Gottesman Libraries, Teachers College, Columbia University); Dr. Ilse DeForest, supra n. x, at 11.

${ }^{23}$ See Living Covenant [the newsletter of the Anchorage, Kentucky Presbyterian Church], April 11, 1999, p. 13, available online at http://www.anchoragepresbyterian.org/pgs2.htm.

${ }^{24}$ See Agnes Snyder, supra note 12, at 237; Austin College history web page, http://www.austincollege.edu/Category.asp?707.

25 “Professor Patty S. Hill, Interview by Miss Chaffee, Summer, 1925,” supra n. x, at 2. Reverend Hill’s attitude was no doubt influenced by raising children during the Civil War, when husbands might go off to war and never come back, and property in the South might be confiscated. He wrote in the 1868 catalog of the Belleville Female Seminary: "Every man should educate his daughter that if, in the rapid revolutions which are now taking place, she should be left without pecuniary resources, she will be able to take care of herself and family. A thoroughly educated, practical woman need neither starve, beg, nor lose her rank in society because she loses her property." See See Living Covenant [the newsletter of the Anchorage, Kentucky Presbyterian Church], March 14, 1999, p. 9, available online at http://www.anchoragepresbyterian.org/pgs1.htm.

${ }^{26}$ See "Patty Smith Hill (1868-1946) Dynamic Leadership in New Directions" in Agnes Snyder, Dauntless Women in Childhood Education 233, 237 (1972).

${ }^{27}$ See id. at 238.

${ }^{28}$ The best single account of Patty Smith Hill's professional career is probably "Patty Smith Hill (1868-

1946) Dynamic Leadership in New Directions,” supra note 12.

${ }^{29}$ Dr. Ilse Forest, supra n. x, at 17-20. Patty Smith Hill had graduated earlier that year from the Louisville Collegiate Institute. See id. at 13. 
influences the German kindergarten pioneer Friedrich Froebel, the American progressive educator Francis W. Parker, and the American philosopher and educator John Dewey. Both Bryan and Hill ended up studying with Parker and Dewey in Chicago, ${ }^{30}$ and Dewey's pragmatism became an important influence for Hill. Parker and Dewey also became interested in the work of Bryan and Hill, and visited the Louisville kindergartens a number of times. ${ }^{31}$ For Hill, Froebel's work in childhood education was important, but his methods of adult-supervised symbolic play were too rigid, and did not adequately emphasize either the development of independent problem-solving in realistic situations, or the public virtue of cooperation necessary for democracy. ${ }^{32}$ Perhaps just as importantly, the Louisville Free Kindergarten Association mixed educational theory with charitable impulses - the word "free" in its title did not mean "liberated," but "tuitionfree" - and the Association's desire to foster cultural and class assimilation in the great American melting pot placed Froebelian teachings in a radically different social context than that in which they originated in Germany.

Immediately upon graduation from the Training School in 1889, Patty Hill became principal of one of the demonstration kindergartens. ${ }^{33}$ There she worked for the next several years, joined by her sister Mary Hill, who had graduated from a later class of the Training School and who was also put in charge of one of the kindergartens. ${ }^{34}$ Patty and Mary together wrote a series of “Typical Lessons for Mothers and Kindergartners," which appeared in Kindergarten magazine from September, 1890 through June, $1891 .^{35}$ In 1893, Patty replaced Anna Bryan as the principal of the entire Training School, a position in which she remained until she left for New York and Columbia University in 1905. ${ }^{36}$

In the meantime, Patty Smith Hill's oldest sister Mildred had become an accomplished pianist, organist, and composer, as well as what we would now call an ethnomusicologist. (Dozens of popular accounts of the origin of "Happy Birthday to You" state that she, like her sisters Patty and Mary, was a kindergarten teacher, ${ }^{37}$ but I am reasonably certain that she was not. ${ }^{38}$ ) Mildred had first studied music with the music

\footnotetext{
30 “Professor Patty S. Hill, Interview by Miss Chaffee, Summer, 1925,” supra n. x, at p. 4.

${ }^{31}$ Dr. Ilse DeForest, supra n. x, at 36-37.

32 See Ann Taylor Allen, “ 'Let Us Live With Our Children’: Kindergarten Movements in Germany and the United States, 1840-1914,” 28 History of Education Quarterly 23 (1988).

${ }^{33}$ Dr. Ilse DeForest, supra n. x, at 23; [HVH 12] Depositions De Bene Esse of Patty Smith Hill and Jessica Hill p. 3.

${ }^{34}$ Id. at 32.

${ }^{35} \mathrm{Id}$.

36 [HVH 12] Depositions De Bene Esse of Patty Smith Hill and Jessica Hill pp. 3, 20.

${ }^{37}$ See, e.g., http://en.wikipedia.org/wiki/Mildred_J._Hill (“Mildred Hill was a kindergarten and Sundayschool teacher, like her younger sister Patty Smith Hill.”); http://www.songfacts.com/detail.php?id=3302 (Mildred and Patty Hill "both taught kindergarten or nursery school”); http://www.musictogether.com/OurHistory (Mildred and Patty Hill were "Kentucky kindergarten teachers"); http://www.littleloomhouse.org/happybirthday.htm (Mildred and Patty "were well-known kindergarten and music teachers”).

${ }^{38}$ First, in Patty Smith Hill's detailed account of collaborating with Mildred on the songs in "Song Stories for the Kindergarten," she always says that she and Mildred would work on the songs at home in the evenings, and that she, Patty, would then take them into the kindergarten to have the children try to sing them. Neither Patty nor Jessica ever mentions anything about Mildred also being a kindergarten teacher.
} 
professor at the Bellewood Female Seminary, of which her father was president. ${ }^{39}$ She became an expert on African-American music, which she transcribed and collected, ${ }^{40}$ and she later studied in Chicago with Calvin B. Cady and William Tomlins, both leading music educators of the era. ${ }^{41}$ Under the pseudonym of Johann Tonsor, Mildred Hill almost certainly wrote an article entitled "Negro music" in the journal Music in December 1892, one of the pioneering accounts of African-American music in mainstream American musical literature. ${ }^{42}$ The article contained many transcriptions of traditional African-American melodies, and described typical characteristics such as syncopation, the blues scale, and "blue notes." More provocatively, the article stated the author's prescient belief, undoubtedly shocking to many readers, that it was these melodies and themes that would eventually give rise to a distinctively American national music. $^{43}$ Scholar Michael Beckerman argues persuasively not only that Mildred Hill

See [HVH 12] Depositions De Bene Esse of Patty Smith Hill and Jessica Hill. Second, an account in Living Covenant, the newsletter of the church where Rev. William Wallace Hill was pastor for 19 years, states that while Patty, Mary, and Jessica all became teachers, "Mildred, the family musician and collector of folk music stayed at home due to poor health." See Living Covenant [the newsletter of the Anchorage, Kentucky Presbyterian Church], April 11, 1999, p. 13, available online at http://www.anchoragepresbyterian.org/pgs2.htm. Mildred Hill may well have had health problems, but it is possible at the same time that the description of Mildred as simply "staying at home" stems from a time in which it would have not occurred to people to view her as a freelance composer working from home. Third, the biographical account of Patty Hill written in the 1920s, presumably with her cooperation, lists the careers of all of the Hill children: Patty, Mary and Jessica all become teachers, and Mildred becomes "an accomplished musician.” Dr. Ilse Forest, supra n. x, p. 15. Lastly, in 1896 Patty Hill herself wrote a history of the Louisville Free Kindergarten Association which goes into great detail about the women who worked under the Association. She lists Mildred Hill as giving vocal classes and accompaniment classes in the "Normal Department." See Patty S. Hill, "Free Kindergarten Association," in J. Stoddard Johnston, ed., Memorial History of Louisville from its First Settlement to the Year 1896, vol. II, p. 287, 289-90. In nineteenth century usage, the word "Normal" in the title of a school or department refers to the training of teachers. See,e.g., Webster's New International Dictionary of the English Language 1665 (2d ed. unabridged 1957) ("normal school. [after F. école normale] A school ... offering a professional course for the training of persons . . . to become teachers."). Thus, Mildred Hill had a position with the Free Kindergarten Association, but it involved teaching music to adults who were studying to become teachers, not to children in the kindergartens. This is the likely source of the confusion about Mildred also being a kindergarten teacher.

39 [HVH 12] Depositions De Bene Esse of Patty Smith Hill and Jessica Hill p. 11. "[Mildred Hill] was a pupil of William Kohnhorst and William Frese in the study of piano, of Henry Busch in ensemble playing, and of Karl Schmidt in theory and composition. In Chicago she studied musical pedagogy with Calvin B. Cady, composition with [Adolph] Weidig, and composition with F.G. Gleason.” Frances Farley Gwinn, Patty Smith Hill in Louisville. p. 121 (Thesis presented to the Faculty of the Department of Education, University of Louisville, 1954; copy on file at the University of Louisville library).

${ }^{40}$ Two notebooks with manuscript transcriptions of spirituals collected by Mildred J. Hill can be found among the papers of Avery Robinson at the University of Oregon Libraries, Special Collections and University Archives. See http://libweb.uoregon.edu/speccoll/guides/music.html.

${ }^{41}$ See id.; Fumiko Shiraishi, "Calvin Brainerd Cady: Thought and Feeling in the Study of Music, "Journal of Research in Music Education, Vol. 47, No. 2 (Summer, 1999), pp. 150-162; “A Pioneer Passes On: William L. Tomlins, 1844-1930,” Music Supervisors’ Journal, October, 1930, p. 19.

${ }^{42}$ See Johann Tonsor, “Negro music,” in Music, vol. III (Nov. 1892 to April 1893), p. 119.

${ }^{43}$ See id. at 121-22 ("When our American musical Messiah see fit to be born he will then find ready to his hand a mass of lyrical and dramatic themes with which to construct a distinctively American music.”). Writing under her own name four years later, Mildred Hill tellingly expressed similar opinions as a brief aside in a lengthy history of music in Louisville: 
wrote this article, but that the article was one of the main sources of inspiration for Antonin Dvorak to compose his "New World Symphony."44 Thus Mildred Hill's name would undoubtedly be better known in American musical history had she not felt the need to write under a male pseudonym.

During her career as a composer, Mildred Hill composed dozens of published songs. As far as I can tell, Mildred never wrote the lyrics to any of her published songs; on all of the copies of published songs that I have been able to locate, the lyrics are credited either to another named author, or, in a few cases, to "Anonymous." 45 In addition to her sister Patty, the lyricists she worked with include Emilie Poulsson; Alva Deane; Charlotte Lay Dewey; R. J. Weston; Laura Frost Armitage; Z. Toppelius; Lydia Avery Coonley; Grace H. Duffield; and Annie E. Moore. ${ }^{46}$ She also set to music poems by Robert Herrick, Eugene Field, Frederick Lawrence Knowles, Edwin Markam, and John Berhoff. ${ }^{47}$ Mildred Hill worked with several music publishers, including the Clayton F. Summy Company of Chicago, Arthur P. Schmidt of Boston, and Rohlfing Sons of Milwaukee. ${ }^{48}$ Apart from "Happy Birthday to You," none of the songs which Mildred Hill composed remains popular today, but that does not mean that they were always so obscure. In 1935, twenty years after Mildred Hill's death, Jessica Hill testified: "I receive royalties regularly from my sister's songs for adults. They are popular and I receive royalties from those adult songs from the publishers." 49

If a history of music in Kentucky were being written, a large portion should be devoted to the music of the negro in our state .. . The great composers of to-day are constantly using the folk music of their respective countries as a basis for their compositions. Dr. Dvorak, the head of the American Conservatory, is attempting to do it for us, but he is a foreigner, and it must remain for an American composer to do this properly. There is no richer field in the South in negro song than Central Kentucky.

Mildred J. Hill, “History of Music in Louisville,” in in J. Stoddard Johnston, ed., Memorial History of Louisville from its First Settlement to the Year 1896, vol. II, p. 85.

${ }^{44}$ See Michael B. Beckerman, New Worlds of Dvorak, 84-87, 95-98 (2003).

${ }^{45}$ For songs for which the words were credited to "Anonymous," see Mildred J. Hill, "Sleep Song” (Boston: Arthur P. Schmidt, 1900) [S14]; Mildred J. Hill, “Smiles and Frowns” (Boston: Arthur P. Schmidt, 1898) [S15]; Mildred J. Hill, “Thistledown” (Chicago: Clayton F. Summy, 1915) [S17]. (All of the above songs are in the collection of the University Archives and Records Center of the University of Louisville.)

${ }^{46}$ See Mildred J. Hill \& Lydia Avery Coonley (German translation by John Berhoff), “The Heart’s Song (Des Herzens Lied)” (Milwaukee: Rohlfing Sons, 1898) [S9]; Mildred J. Hill \& Grace H. Duffield, "With All My Heart” (Chicago: Clayton F. Summy Co., 1908) [S 19]; Emilie Poulsson, Holiday Songs (1912) (a collection of 103 songs, including 17 songs for which Mildred Hill wrote the music); Mildred J. Hill \& Annie E. Moore, Songs of Nature and Childlife (1898). One of the songs in "Holiday Songs" for which Mildred Hill composed the music was intended specifically for birthday celebrations; ironically, it has fallen into complete obscurity, while "Good Morning to All," with a few new words, has become the most popular birthday song of all time. See Laura Frost Armitage \& Mildred J. Hill, "Song for a Child's Birthday,” in Emilie Poulsson, Holiday Songs 102 (1912).

47 See Mildred Hill \& John Berhoff, “A Secret,” (Milwaukee: Rohlfing Sons, 1898); Mildred Hill \& Eugene Field, "Swing High and Swing Low” (Milwaukee: Rohlfing Sons, 1898); Mildred Hill \& Robert Herrick, “To Anthea - An Old English Love Song” (Boston: Arthur P. Schmidt, 1900); Mildred Hill \& Edwin Markham, “Joy of the Morning," (Chicago: Clayton F. Summy, 1908). (All of these songs are in the collection of the University Archives and Records Center of the University of Louisville.)

${ }^{48}$ See supra notes $21-23$.

49 [HVH 12] Depositions De Bene Esse of Patty Smith Hill and Jessica Hill p. 34. 
In 1889, Mildred and Patty began to collaborate on writing songs for children, ${ }^{50}$ which would eventually be published in 1894 in a collection entitled "Song Stories for the Kindergarten." 51 They had very particular goals in mind for their project. Patty testified:

The songs for children at that time were of two types. One group came over from Germany collected by [Friedrich] Froebel himself which were so poor both musically and judged from the standpoint of the ability of the child to sing, that it was necessary to discard them. The first attempt to improve upon that was by a German family by the name of Hailmann, if I remember correctly. They did not create their songs. They tried to get good music but it was not fitted to the idea and the emotions in the song nor fitted to the musical ability of young children. When my sister Mildred and I began the writing of these songs [referring to "Song Stories for the Kindergarten"] we had two motives. One was to provide good music for children. The second was to adapt the music to the little child's limited ability to sing music of a complicated order. Also, we wished the song to express the idea and the emotions embodied in the words . . . .52

Mildred Hill was 30 at the time; Patty Smith Hill was 22. They entered into their songwriting project with great seriousness and zeal, and they had the advantage that, since Patty was the principal of a kindergarten, they could repeatedly try out drafts of a song on kindergarten students. One of their first efforts was the song "Good Morning to All," the melody of which became the melody of "Happy Birthday to You." According to Patty, she would first write the words of the songs, and then ask her sister to compose a melody "to express those words and emotions and ideas fitted to the limited musical ability of a young child." 53 They recognized that "musically the comfortable range, easy intervals and repetition are evident requirements for a successful kindergarten song which is to be sung by the children." 54 Once they had a draft, Patty would take it into the kindergarten:

\footnotetext{
${ }^{50}$ [HVH 12] Depositions De Bene Esse of Patty Smith Hill and Jessica Hill p. 4.

${ }^{51}$ Mildred J. Hill \& Patty S. Hill, Song Stories for the Kindergarten (Chicago: Clayton F. Summy, 1894).

${ }^{52}$ [HVH 12] Depositions De Bene Esse of Patty Smith Hill and Jessica Hill p. 4. Patty Hill's reference to "the Hailmann family" is likely to the family of William Nicholas Hailmann, a German-Swiss immigrant to Louisville who became very prominent in early childhood education, and served as president of the Froebel Institute of North America. See http://www.froebelfoundation.org/people/Hailmann.html.

${ }^{53}$ [HVH 12] Depositions De Bene Esse of Patty Smith Hill and Jessica Hill p. 12.

${ }^{54}$ Patty Smith Hill, "Music in the Kindergarten,” p. 41(a) (unpublished lecture notes, Patty Smith Hill collection, Filson Historical Society, Louisville, Kentucky). These lecture notes give a remarkably detailed account of Patty Hill's thoughts about music in the kindergarten, and her industriousness in experimenting with music from all sources, including cries from vendors of fruits and vegetables, coal, and newspapers, which she collected in the streets of Louisville. She also demonstrates her awareness of branding and trademarks: "[S]treet vendors have musical calls which protect their trade as a trade mark does in higher grades of economic life. For example, the colored coal peddlers protect themselves by musical calls which announce to their special patrons that they and no other peddlers are coming on ready for trade [she then evidently sings one of the calls during the lecture].” Id. at 28-29.
} 
[A draft of the song] would be written and I would take it into the school the next morning and test it with the little children. If the register was beyond the children we went back home at night and altered it and I would go back the next morning and try it again and again until we secured a song that even the youngest children could learn with perfect ease $\ldots{ }^{55}$

As Patty Hill noted, "[i]t is an excellent plan to throw the children on their own resources occasionally, by withdrawing the voices of the teachers and the support given by the accompaniment. This is an excellent test for a song which little children can really sing., ${ }^{56}$

In the case of "Good Morning to All," the melody that resulted from such a meticulous process deserves considerably more appreciation than it usually gets. A melody that is simple enough to be sung and remembered by kindergarten students, yet within those limits expressive and interesting, is also a melody that adults who are otherwise not musically inclined might also learn, remember, and sing with enthusiasm at a few celebrations every year. Professor Stephen Douglas Burton, who until his retirement in Spring 2006 held the Heritage Chair in Music at George Mason University, has expressed his own appreciation for the "Good Morning to All" melody:

My own feeling is that the form of the melody has a great deal to do with the popularity of [Happy Birthday to You] - it is easy to remember! It consists simply of a short six-note motive (melodic fragment) .... Then the words repeat and the motive repeats a step higher; it repeats a third time yet higher and merges into a fourth repetition coming back down again, a perfect arch form or what Leonard Bernstein used to call the 'ready (1) aim (2) fire $(3+4)$ method of composition. . . . Mildred Hill's study of Negro spirituals undoubtedly had a strong influence on this type of motivic construction, not to mention the chantlike repetition of the words - which incidentally gives you time to think of the person's name before you have to sing it. ... Symmetry, repetition, and variation - all used to make the tune both memorable and interesting. ${ }^{57}$

Was the tune original? In two books and one article written between 2001 and 2005, Professor Kembrew McLeod of the University of Iowa claims that it wasn't:

[T] he Hill sisters didn't compose the melody all on their own. There were numerous popular nineteenth-century songs that were substantially similar, including Horace Waters’s "Happy Greetings to All,” published in 1858. The Hill sisters' tune is nearly identical to other songs, such as "Good Night to All," also from 1858; “A Happy New Year to All,” from 1875; and "A Happy Greeting to

\footnotetext{
${ }^{55}$ [HVH 12] Depositions De Bene Esse of Patty Smith Hill and Jessica Hill p. 7. According to Jessica Hill she was also enlisted as a test singer while her sisters worked on the songs. See id. at 31-32.

${ }^{56}$ Patty Smith Hill, "Music in the Kindergarten,” p. 40 (unpublished lecture notes, Patty Smith Hill collection, Filson Historical Society, Louisville, Kentucky).

${ }^{57}$ Colleen Kearney Rich, "That Familiar Little Ditty: Mason composer gives historical perspective to a song we all know by heart,” Mason Spirit (the alumni magazine of George Mason University), Fall 2003, available online at http://www.gmu.edu/alumni/spirit/fall03/ditty.html.
} 
All,” published 1885. This commonality clearly suggests a freely borrowed melody (and title, and lyrics) that had been used and reworked throughout the century. ${ }^{58}$

In the world of copyright and music, those are fighting words. If the melody of "Good Morning to All" were not only "substantially similar" but "nearly identical" to other previous songs that the Hill sisters knew and "freely borrowed" from, that melody would lack originality, a condition of copyright protection. McLeod's claim of lack of originality is echoed on many websites. ${ }^{59}$

McLeod apparently did not examine the alleged predecessors to "Good Morning to All” himself, but relied on the assertions of others. Had he looked closer, he would have realized, at least, that "Happy Greetings to All” and "A Happy Greeting to All” were the same song published under different titles. ${ }^{60}$ McLeod also softens the assertions of one of his sources, and exaggerates those of the other. Gene Claghorn claims that "Good Morning to All” is identical to "Happy Greetings to All”; "[a]ctually," he states, “['Good Morning to All'] appeared as 'Happy Greetings to All' . . . in 1858." This is patently false, but McLeod softens it, citing Claghorn for the proposition that "a very similar song was published by Horace Waters in 1858 as 'Happy Greetings to All.,"61 McLeod exaggerates the assertions of James J. Fuld, author of the masterpiece of musical

\footnotetext{
${ }^{58}$ Kembrew McLeod, Freedom of Expression ${ }^{\circledR}$ : Overzealous Copyright Bozos and Other Enemies of Creativity 16 (2005); see Kembrew McLeod, Owning Culture: Authorship, Ownership, and Intellectual Property Law 50-54 (2001); Kembrew McLeod, "Musical Production, Copyright and the Private Ownership of Culture," in Justin Lewis and Toby Miller, eds., Critical Cultural Policy Studies: A Reader 240, 244 (2003).

${ }^{59}$ See, e.g., J. Byron, "Exposing the Happy Birthday Story," http:/www.kuro5hin.org/story/2003/7/5/112441/6280 ("I'm not even sure the court knew of earlier publications that were similar to Good Morning to All: Happy Greetings to All, 1858, Good Night to You All, 1858, A Happy New Year to All, 1875, Happy Greeting to All, 1885. Notice a pattern here? i.e. folk song”); “Happy Birthday, We'll Sue,” http://www.snopes.com/music/songs/birthday.asp (“(Ironically, in light of the copyright battles to come, "Good Morning to All" bore more than a passing resemblance to the songs "Happy Greetings to All" and "Good Night to You All," both published in 1858.)"); http://globalia.net/donlope/fz/songs/Happy_Birthday_To_You.html ("Happy Birthday to You ... Melody apparently based on "Happy Greetings To All" and/or "Good Night To You All" (both published in 1858)").

${ }^{60}$ In his book "Owning Culture" and his article "Musical Production, Copyright and the Private Ownership of Culture," McLeod cites Gene Claghorn for the song "Happy Greetings to All” and James Fuld for the song "Happy Greeting to All.” Kembrew McLeod, "Musical Production, Copyright and the Private Ownership of Culture," supra note 57, at 244; Kembrew McLeod, Owning Culture, supra note 57, at 53 (both citing Gene Claghorn, Women Composers and Songwriters: A Concise Biographical Dictionary 96 (1996) and James J. Fuld, The Book of World-Famous Music, Classical, Popular and Folk 268 (5 ${ }^{\text {th }}$ ed. 2000). Claghorn and Fuld both note that the song they are referring to was published in "The Anniversary and Sunday School Music Book No. 2,” published by Horace Waters; Fuld correctly quotes the song's title, while Claghorn adds an "s" to "Greeting." See [S3] (images of that book). In Freedom of Expression ${ }^{\circledR}$, McLeod alters his claim slightly, referring to "Happy Greetings to All” and "A Happy Greeting to All, published 1885." I suspect that whatever 1885 publication McLeod is referring to, it is a publication of the same song published in 1858 by Horace Waters as "Happy Greeting to All." That song was very widely republished in the late nineteenth and early twentieth centuries, sometimes under the title "A Happy Greeting to All.” See [S4], [S5], [S6].

${ }^{61}$ Kembrew McLeod, "Musical Production, Copyright and the Private Ownership of Culture," supra note 57, at 244; Kembrew McLeod, Owning Culture, supra note 57, at 53.
} 
history and bibliography "The Book of World-Famous Music, Classical, Popular and Folk." 62 Fuld states that the song "Good Morning to All" -- and note that he does not consider melody and lyrics separately -- bears "a similarity” to "A Happy New Year" and “Good Night to You All,” and a “considerable similarity” to "Happy Greeting to All”. 63

This is not the place for an extended musicological analysis, but I don't think one is needed. The lyrics of two of the songs that Fuld mentions are certainly similar to "Good Morning to All," in that they involve heavy repetition of a simple greeting. The refrain of "Happy Greeting to All” (unlike "Good Morning to All," it has verses and a refrain that use two different melodies) is "Happy Greeting to all! Happy Greeting to all! Happy Greeting, happy greeting, happy greeting to all!" ${ }^{4}$ Meanwhile, the first lines of "A Happy New Year" are "What a happy new year! What a happy new year! What a happy, what a happy, what a happy new year!”65 “Good Night to You All” doesn’t even exhibit that level of similarity: its entire lyrics are "Good Night to you all, and sweet be your sleep! May angels around you Their vigils keep! Good night! good night! good night! good night!"66

McLeod, unlike Fuld, singles out the melodies of these songs and claims that they are "nearly identical" to that of "Good Morning to You." It is notoriously difficult to compare the melodies of two compositions in words alone, so I invite those of you who are comfortable with reading music to examine the scores, ${ }^{67}$ and I invite all of you to listen to a few mp3 files, for which I am greatly indebted to Ms. Kat Caverly of Kat Caverly Enterprises, Inc. in New York City. ${ }^{68}$ The melody of "Happy Greetings to All," the song which Mr. Fuld states bears "considerable similarity” to "Good Morning to All," is very, very different. Not only do the first two lines start with a high note and then dip down, which give the song quite a different feel; not only does the chord progression vary in the third line; but the melody employs dotted notes and triplets. Those dotted notes and triplets give the song a certain air, but a very different air, and they also make the song much harder to sing, both for kindergarten students and for musically unsophisticated adults - a crucial factor in distinguishing "Good Morning to All” from other melodies.

"Good Night to You All” is written as a three-part round. If one lops off the third part, the first two parts taken together are rhythmically identical to "Good Morning to All." The melodies, however, are quite different, and the whole second part of "Good Night to You All" is oriented towards ending unresolved on the dominant (i.e. the note "so" on the "do re mi" scale), precisely because we are at that point only two-thirds of the

\footnotetext{
62 James J. Fuld, The Book of World-Famous Music, Classical, Popular and Folk (5 ${ }^{\text {th }}$ ed. 2000).

${ }^{63} \mathrm{Id}$. at 268. Fuld notes that "Harold Barlow, New York City, advised the author of these similarities." See id., 268 n. 3.

${ }^{64}$ See [S5].

65 See [S1].

${ }^{6}$ See [S3].

${ }^{67}$ See [S1], [S3], [S5].

${ }^{68}$ See [S2], [S4], [S6]. Kat Caverly Enterprises, Inc. produces, among other things, excellent electronic greeting cards. See http://www.photocartoonist.com/index.html. Some of those greetings cards include music, hence Ms. Caverly's interest in the copyright status of "Happy Birthday to You.”
} 
way through a three-part piece. "A Happy New Year" is in some ways the most similar of the three, but it too has some strikingly different features, including sixteenth notes and dotted eighth notes, which once again make it snappy but more difficult to sing.

Of course, there are really two different questions here. One is purely a question of copyright law: assuming we could show that Mildred and Patty Hill had access to these earlier songs, would "Good Morning to All” be "substantially similar" to any of them, so that it would be held to infringe? The second is a broader question of policy and attitude: were Mildred and Patty Hill really doing something that involved a lot of creative work, or were they just incrementally tweaking a melody within a folk tradition? I think the answer to both questions is favorable to the Hill sisters. To be sure, they did not invent the rhythmic, melodic, or harmonic vocabulary that they were using. ${ }^{69}$ But they managed to put together a melody that is significantly different from all known previous melodies; that delivers some drama; but that is at the same time extremely simple, using a major scale with no accidentals, ${ }^{70}$ remaining within a range of one octave, and limiting itself to half and quarter notes. ${ }^{71}$ That, I think, is an achievement worthy of the incentive of copyright protection.

Worthy, perhaps, but was copyright law actually needed as an incentive for composing and distributing the song? At one point, Patty Hill suggests that she and her sister weren't really interested in publication: "We did not [write] the songs for publication. We wrote them for the group of children I was teaching and they were so superior to any other music on the market at the time that the public demanded the publication."72 Frankly, although I have a great deal of respect for Patty Hill, I think the notion that "the public demanded the publication" of her and Mildred's songs may be a bit of excusable vanity on her part. Jessica Hill's recollection was that when she was around the house while Mildred and Patty were composing the songs for "Song Stories for the Kindergarten," and "Good Morning to All” in particular, her sisters did have publication in mind: "You must remember that I was only fifteen at the time, fourteen or fifteen, and that I was not interested in education and that therefore I had no connection

\footnotetext{
${ }^{69}$ The reader may also recall that Stephen Douglas Burton opined that Mildred Hill was "strongly influenced" by her study of Negro spirituals when composing "Good Morning to All." See Colleen Kearney Rich, "That Familiar Little Ditty: Mason composer gives historical perspective to a song we all know by heart," supra note 57. Yet if "Good Morning to All” is notable for what it took from negro spirituals, namely, as Burton mentions, "motivic construction" and "chantlike repetition," it is also notable for what it did not take, both rhythmically and harmonically. The melody of "Happy Birthday to You" is completely unsyncopated, and does not use a blues scale or blue notes. It thus lacks the typical characteristics of Negro spirituals that Mildred Hill documented in her transcriptions of "Negro Songs," and articulated as "Johann Tonsor" in the famous article in Music magazine. See supra note 42.

${ }^{70}$ That is, no notes outside of that scale - technically, no sharps, flats, or naturals other than the sharps or flats used in the key signature to indicate the key in which a piece is notated. "Good Morning to All" was originally written in the key of $\mathrm{G}$ major, and hence had a key signature with one sharp, an F.

${ }^{71}$ Of course, when the melody is used for "Happy Birthday to You," one has to split the quarter note accompanying the one-syllable word "good" in "Good Morning to All" in order to accommodate the twosyllable word "happy." Although that yields some eighth notes, the melody remains simple enough to be sung by a large percentage of the world's population.

${ }^{72}$ [HVH 12] Depositions De Bene Esse of Patty Smith Hill and Jessica Hill p. 6.
} 
with [Good Morning to All] whatever except as a sister who was immensely interested in the success of her two sisters in writing a book."73

More tellingly, it is quite clear that the Hill sisters knew about the danger of losing copyright protection if the songs were published before they were registered at the Copyright Office, and that they took steps to avoid that danger. They taught their songs not only to the children in Patty Hill's kindergarten, but to adults who were studying to be teachers at the Louisville Training School for Kindergartners. However, as for the teacher trainees, testified Patty Hill, "they were told specifically that [the song] must never appear in print, that the book would be published and that they could not even from memory write it down and publish it. . . . [T] hey knew they had to depend on their own ear for the use of it."74 In short, although one can never answer the question whether the song would have been composed and published without the incentive of copyright protection, Mildred and Patty Hill were hardly innocents. They knew about copyright protection and they made sure they didn't forfeit it. They may well have understood that they would have a harder time finding a publisher if they did not maintain copyright protection. Copyright concerns about the song entered at its inception.

\section{The Emergence and Triumph of “Happy Birthday to You””}

If the song "Good Morning to All” had never gained alternative lyrics, it would undoubtedly have suffered the same decline into obscurity as have the other songs in "Song Stories for the Kindergarten." Early in the second decade of the 1900s, however, "Happy Birthday to You" began appearing in a variety of songbooks as alternative text for the "Good Morning to All” melody. Why wasn't there already a standard birthday song at that time? The answer may lie in the fairly recent emergence of birthday celebrations. According to scholar Elizabeth Pleck, birthday parties did not become common even among wealthy Americans until the late 1830s; modern birthday cakes emerged after 1850; and peer-culture birthday parties, involving children of the same age as the child whose birthday was being celebrated, emerged between 1870 and 1920, after American urban public schools became age-graded. ${ }^{75}$ Thus, the prerequisites for the development of a standard birthday song - the proliferation of birthday celebrations that involved a dramatic moment at which a group of invitees, often children, addressed the honoree -- may not have been in place until shortly before "Happy Birthday to You" started to become popular.

Whatever the reason may be, "Happy Birthday to You” became extremely well known as the standard birthday song in the two decades between 1915 and 1935 . Its use in two 1937 films, "On the Avenue"76 and "Stella Dallas,"77 is quite telling. In both

\footnotetext{
73 [HVH 12] Depositions De Bene Esse of Patty Smith Hill and Jessica Hill p. 31.

${ }^{74}$ [HVH 12] Depositions De Bene Esse of Patty Smith Hill and Jessica Hill pp 23-24.

${ }^{75}$ See Elizabeth H. Pleck, Celebrating the Family: Ethnicity, Consumer Culture, and Family Rituals 143, 144-45, 151 (2000).

76 “On the Avenue” was produced by Twentieth-Century Fox Film Corporation, directed by Roy Del Ruth, and starred Dick Powell and Alice Faye. See http://www.imdb.com/title/tt0029345/.
} 
films, the "Good Morning to All” tune is played, in a purely instrumental version, for a very brief period, to introduce birthday scenes. The directors of those films evidently believed that the films' nationwide audiences would be familiar with the song, and would need only a brief musical cue to trigger the birthday associations.

Since the 1930s, the song has only grown in popularity, a popularity that can be demonstrated with a stream of accolades, anecdotes, and statistics. In a 1999 press release, the American Society of Composers, Authors and Publishers (ASCAP) announced that "Happy Birthday to You" was "far and away" the most popular song of the twentieth century, having been "publicly performed hundreds of millions of times.,"78 The Songwriters Hall of Fame awarded the song its "Towering Song” award in 1996, pronouncing that its melody "is quite likely the most sung music in history, including all the output of the three Bs, Beethoven, Bach and the Beatles."79 The Guinness Book of World Records has deemed "Happy Birthday to You" the most frequently sung song in English, ahead of "For He’s a Jolly Good Fellow" and “Auld Lang Syne. ${ }^{80}$ ASCAP focuses on public performances, of course, because they are the source of its income, since private performances are not within the scope of the exclusive rights granted by copyright law. Yet for every public performance of the song, there are probably scores of private performances, around dinner tables at family birthday celebrations. It is likely, in fact, that "Happy Birthday to You" has one of the highest ratios of private to public performances among well-known songs - if the birthdays of any substantial percentage of the over 300 million people living in the United States are marked with at least one private performance of the song, it doesn't take long to get to a billion performances.

According to the Internet Movie Database, the song has appeared in 143 movies; ${ }^{81}$ it has also appeared in countless advertisements, for everything from Toyota and Oldsmobile automobiles, Aetna insurance, the Oregon State Lottery and the Minnesota Zoo, to Frosted Flakes and Cheerios cereals, Fleischmann's margarine, Browny paper towels, Petsmart, and the H-E-B Grocery chain. ${ }^{82}$ The world's first singing telegram, on July 28, 1933, featured "Happy Birthday to You," estimated that the song had been used in one-and-a-half million singing telegrams. ${ }^{84}$ For those in adulthood in the early 1960s, the defining performance of the song was probably Marilyn Monroe’s sultry serenade to President John F. Kennedy in Madison Square

\footnotetext{
77 "Stella Dallas" was produced by the Samuel Goldwyn Company, directed by King Vidor, and starred Barbara Stanwyck, whose performance earned her an Oscar nomination for Best Actress in a Leading Role. See http://www.imdb.com/title/tt0029608/.

${ }^{78}$ ASCAP Announces Top 25 Songs of the Century (Press Release December 27, 1999) (available at http://web.archive.org/web/20030111005247/http://www.ascap.com/press/1999/songs-122799.html).

${ }^{79}$ See http://songwritershalloffame.org/award_recipient_detail.asp?ceremonyId=8\&awardRecipientId=67.

${ }^{80}$ See The Guinness Book of World Records 1998, p. 180 (1997).

${ }^{81}$ See http://www.imdb.com/name/nm0384530/.

${ }^{82}$ See the listing for the song in the ASCAP ACE Title Search online database, http://www.ascap.com/ace. The ASCAP title code or "T-Code" for the song is 380008955.

${ }^{83}$ See "Musical Telegrams: A Performance Art Since '33," New York Times, August 26, 1987, p. C19; "George Oslin, 97, Creator of the Singing Telegram," Chicago Tribune, October 31, 1996, p. 11. Of course, the "singing telegram" wasn't a telegram at all, but a telephone call - one of the attempts of the telegraph industry to cope with its own decline as telephones proliferated.

${ }^{84}$ See "Miss Patty," The New Yorker, March 8, 1941, p. 12.
} 
Garden on May 19, 1962. ${ }^{85}$ Fewer may know that the song has also received attention from "serious" classical composers: both Igor Stravinsky and Aaron Copland have written pieces based on the "Good Morning to All" melody. ${ }^{86}$

When Americans assume that their cultural products are spread throughout the world, they are often mistaken, but in the case of "Happy Birthday to You” they wouldn't be. The song appears to be widely sung in most corners of the world, either in English, or with birthday-appropriate lyrics in the local language. A thread of postings about birthday songs on the website Wordreference.com reveals that some other countries do have traditional birthday songs of their own, but it also reveals that birthday lyrics for the "Good Morning to All” melody have been written and sung in Arabic, Basque, Catalan, Dutch, Finnish, French, German, Hebrew, Indonesian, Irish, Italian, Korean, Lithuanian, Mandarin Chinese, Norwegian, Portuguese, Spanish, and Tagalog. ${ }^{87}$ It's hard to imagine that there are hard statistics that could prove or disprove the claim made in the title of this article, but if any reader knows of a serious contender for the title of world's most popular song, I would like to know it.

The more popular "Happy Birthday to You" has become, the more money it has made. In the late 1940s and early 1950s, the song generated revenues in the range of $\$ 15,000$ to $\$ 20,000$ per year. ${ }^{88}$ By 1960 , that figure was closer to $\$ 50,000$, and by 1970 ,

${ }^{85}$ See http://www.youtube.com/watch?v=w3IzpazVl-I. While on Youtube, you could consider watching Paris Hilton singing "Happy Birthday to You" to Hugh Hefner, http://www.youtube.com/watch?v=yGGNfQ3Ulsg; former Spice Girl Geri Halliwell singing "Happy Birthday to You" to Prince Charles, http://www.youtube.com/watch?v=LHhBLFMH8Ac; The Jackson Five singing "Happy Birthday to You" in English and Spanish, http://www.youtube.com/watch?v=9wEzFERNmPw; Whitney Houston singing "Happy Birthday to You:" to her father, http://www.youtube.com/watch?v=Gv_AclzFzAk; and Saddam Hussein and his family singing "Happy Birthday to You" in English and Arabic to his youngest daughter, http://www.youtube.com/watch?v=l82jokyf89Y.

${ }^{86}$ See Igor Stravinsky, Greeting Prelude, for the eightieth birthday of Pierre Monteux (1955), Library of Congress Call Number M1045.S913 G7; Aaron Copland, Happy Anniversary; A well-known tune arranged for symphony orchestra (1971) (composed to celebrate the birthday of Eugene Ormandy), Library of Congress Call Number M1060.H573 H32.

${ }^{87}$ See http://forum.wordreference.com/showthread.php?t=198776. Another clue to the popularity of the song in countries like Germany is the development of parody lyrics that, in my experience, are widely known among children. If, in the United States, kids know (among others) "Happy birthday to you, you live in a zoo, you look like a monkey, and you smell like one too," kids in Germany are likely to know "Happy birthday to you, Marmelade im Schuh, Aprikose in der Hose, und ein Bratwurst dazu” (i.e., marmalade in the shoe, apricot in the pants, and with those a bratwurst - a nonsense rhyme).

${ }^{88}$ The figures throughout this paragraph come from accounting statements filed in connection with litigation over the management of a trust created by Jessica Hill's will. Three charts summarizing the information from those documents, and indicating the specific document from which each raw figure came, are available at [A2], [A3] and [A4]. To calculate the total income generated by the song, I made two assumptions.

First, I assumed that the income received by the Jessica Hill trust directly from the publisher represented one-third of the total income collected by the publisher. This is based upon an affidavit by Alvin J. Burnett, trustee of the Jessica Hill trust, stating that all rights in "Good Morning to All" and "Happy Birthday to You” were assigned to the Clayton F. Summy Company in 1944 in return for a onethird share of revenues generated by the song. See [JMH 14], pp. 3-4.

Second, I assumed that the amounts that ASCAP paid to the Jessica Hill trust represent $50 \%$ of the song's total public performance revenues, and that the other $50 \%$ is being paid to the publisher. There is a 
over $\$ 75,000$. But the really dramatic increase in revenue came in the 1980 s. By the early 1990s, the song was generating well over $\$ 1$ million per year, ${ }^{89}$ and by 1996, reported Forbes magazine, it was "pull[ing] in slightly less than \$2 million a year."90 Revenues from public performances of the song, collected and distributed by ASCAP, grew steadily. In 1994 and 1995, ASCAP distributed about \$469,000 and \$452,000, respectively, to the owners of "Happy Birthday to You," well over one percent of ASCAP's total distributions for those years, ${ }^{91}$ a remarkable figure in light of the fact that there were several million songs in ASCAP's repertory at the time. But there was even more dramatic growth in other licensing revenues collected directly by the publisher or by the Harry Fox Agency, for the song's use in films, plays, television shows, advertisements, music boxes, and the like. ${ }^{92}$ While public performance revenues

puzzle about the distribution of public performance income that may throw this latter assumption into doubt. Only Mildred Hill ever became a member of ASCAP (posthumously); Patty Hill never became a member, and is still listed as a non-member in the ASCAP online database. The ASCAP database currently lists Mildred and Patty Hill as co-authors of the song, and normally co-authors, when registering a song with ASCAP, would indicate that some percentage of author revenues from the song would go to each author. ASCAP documents, however, suggest that for songs published before 1966, ASCAP will only pay out the member's share of the revenues, not the non-member's share. See Compendium of ASCAP Rules and Regulations, and Policies Supplemental to the Articles of Association \$3.4.2, available at http://www.ascap.com/reference/compendium_rules_regs_rev062906.pdf. Thus, either (1) Mildred Hill was designated to receive $100 \%$ of revenues from "Happy Birthday to You" when the song was registered; (2) ASCAP paid Patty Hill her share of the song's revenues even though she was not an ASCAP member, or (3) ASCAP did not pay out Patty Hill's share, and the public performance income received by the Jessica Hill trust represents less than $100 \%$ of the author's share of the revenues apportioned to the song by the ASCAP formula. My guess is that (1) is the correct answer, but that is only a guess.

${ }^{89}$ This figure is consistent not only with the information gathered from the litigation involving Jessica Hill's trust, but also with a 1988 estimate of about \$1 million in annual revenues published in two New York Times articles written when the parent company of Summy-Birchard, the music publisher that owned "Happy Birthday to You," was sold to Warner Communications, Inc. See Geraldine Fabrikant, "Put a Song in Your Portfolio: 'Happy Birthday' Is for Sale,” The New York Times, Oct. 20, 1988, p. A1; Geraldine Fabrikant, “The Media Business: Sound of a \$25 Million Deal: 'Happy Birthday' to Warner,” The New York Times, Dec. 20, 1988, p. D1. Three years earlier, a lawyer for Summy-Birchard said that "performance proceeds from 'Happy Birthday to You' bring two 'low six-figure" checks each year to Summy-Birchard and the Hill Foundation.” N. Smith, "Sisters Have a Hit, Year In and Year Out," Los Angeles Times, April 5, 1985, View, Life \& Style Section p. 1. That is also consistent with the Hill Trust litigation information, once one realizes that "performance proceeds" were by the mid-1980s not the most important source of revenue for the song.

${ }^{90}$ Robert LaFranco, "Happy Birthday to us: a few years ago entertainment companies were dumping their music publishing operations. Foolish.," Forbes Magazine, March 11, 1996, p. 113. The current owner of the right to receive the royalties that were once paid to Jessica Hill's trust, see supra note 58 , is the Association for Childhood Education International, a tax-exempt organization that is required to file an annual return, IRS Form 990, that is available to the public. The last three returns available, for the fiscal years ending June $31,2004,2005$, and 2006 , indicate royalty income of $\$ 584,352$; $\$ 631,866$; and $\$ 738,510$ respectively. If we assume that this income is derived from "Happy Birthday to You," and if we assume that $35 \%$ is coming from ASCAP and 65\% is coming from Summy-Birchard under the terms suggested in note 58 , supra, that would suggest that total revenues from the song were $\$ 1,548,533 ; \$ 1,674,445$; and $\$ 1,957,052$ for those respective years.

${ }^{91}$ See “ASCAP Receipts Surpass \$436 Million Mark in 1995” (ASCAP Press Release), available at http://web.archive.org/web/19980503172613/ascap.com/press/receipts-021596.html (ASCAP made total distributions of \$318.8 million in 1994 and \$356.7 million in 1995).

${ }_{92}$ The Harry Fox Agency issues mechanical licenses, which cover sound recordings of musical works, and until recently also issued synchronization licenses, which cover use of a musical work in an audiovisual 
accounted for $85-90 \%$ of revenues in the 1960 s, by the early 1990 s they only accounted for about 35\%. Much of the song's revenues may thus come from its use to lend an air of authenticity to fictional birthday scenes in movies and on TV - an authenticity that is generated by hundreds of millions of royalty-free private performances every year.

The aggressive licensing program that has produced these revenues has even generated news stories of its own. "Happy Birthday to You" was widely mentioned as one of the principal songs at play when ASCAP demanded that the Campground Association of America, and its member the Girl Scouts, obtain public performance licenses to sing songs in its repertoire; ${ }^{93}$ after public outcry, ASCAP backed down. ${ }^{94}$ Many restaurant chains, including Red Lobster, Outback Steakhouse, and Romano's Macaroni Grill, have developed birthday songs of their own in part to avoid having to purchase live music performance licenses from ASCAP. ${ }^{95}$ And documentary filmmakers worry about including footage from birthday parties, for fear of having to clear rights to "Happy Birthday to You" - a difficulty that has featured in the current unavailability of the civil rights documentary "Eyes On The Prize," which features footage of a group singing “Happy Birthday To You” to Martin Luther King, Jr. ${ }^{96}$

The history of "Good Morning to All" and "Happy Birthday to You" spans extraordinary changes in the distribution of music, the music publishing industry, and music copyright law. When "Good Morning to All” was published in 1893, the sound recording industry was in its infancy, and commercial radio broadcasting would not arrive for almost three more decades. ${ }^{97}$ People learned songs through sheet music and live performances; many of those performances were by family and friends in informal settings. That has not been true for at least the last two generations. Most people are now consumers of recorded music, delivered through ever more ubiquitous channels, from terrestrial radio (which only recently began to need that adjective), vinyl records, movies and TV, to transistor radios and cassette tapes, to CDs, to peer-to-peer networks, mp3 players and satellite radio. "Happy Birthday to You" is probably one of the few songs that people in the last two generations learned through live performances in family or community settings, and many of the others were likely children's songs - "Twinkle,

work such as a movie or a television show or advertisement. See M. William Krasilovsky \& Sydney Shemel, This Business of Music 157-58 $\left(9^{\text {th }}\right.$ ed. 2003). “Happy Birthday to You” likely generates very little in mechanical license revenue, since the song is recorded infrequently.

${ }^{93}$ See, e.g., Lisa Bannon, “The Birds May Sing, But Campers Can’t Unless They Pay Up,” The Wall Street Journal, August 21, 1996, p. A1.

${ }^{94}$ See Elisabeth Bumiller, "Battle Hymns Around Campfires: Ascap Asks Royalties From Girl Scouts, and Regrets It,” New York Times, December 17, 1996, p.1; “ASCAP Clarifies Position on Music in Girl Scout Camps” (ASCAP Press Release), http://web.archive.org/web/19980503172433/ascap.com/press/ascap082696.html

95 See "When It Comes To Birthdays, Song Doesn't Remain The Same," The Press of Atlantic City, March 13, 1002, p. B8.

${ }^{96}$ See K. Matthew Dames, “Copyright Conundrum: Documentaries and Rights Clearance,” Information

Today, June 1, 2006, p. 24.

${ }^{97}$ See http://ieee-virtual-museum.org/collection/event.php?id=3456885\&lid=1 (the first radio broadcast of an audio signal took place on December 24, 1906) Christopher H. Sterling \& John M. Kitross, Stay Tuned: A History of American Broadcasting 66 (2002) (the first commercial radio broadcast was by KDKA Pittsburgh on November 2, 1920). 
twinkle, little star" and the like - that they no longer sing or hear as grown-ups. Thus, for many people -- and you, dear reader, should consider whether you are among them -"Happy Birthday to You” is the only secular song passed down through an oral folk song tradition and still sung in adulthood. ${ }^{98}$ No wonder it's a surprise to find that the song is not a folk song of unknown origin. But it's not. ${ }^{99}$

Tracing control of the songs provides a map of the major changes in the music publishing industry over the last century. "Good Morning to All” was first published printed and distributed to the public as part of the book "Song Stories for the Kindergarten"-- by an individual, Clayton F. Summy, as the sole proprietor of a music business that he had founded in 1888. The business encompassed not only music publishing, but the retail sale of sheet music and, for a time, pianos. ${ }^{100}$ Summy incorporated in 1895, but under an old-style incorporation statute that granted corporate charters for a limited period of time, based upon a specific dollar amount of capital stock. ${ }^{101}$ Two years before his death in 1932, Summy sold the business to an accountant by the name of John F. Sengstack. ${ }^{102}$ Sengstack continued to operate the company essentially as a family business - when he retired in 1958, his son, David K. Sengstack, replaced him as the company's president - but the company expanded substantially in the 1950s and 1960s, through the purchase of no less than eight other music publishers. ${ }^{103}$ One of those purchases - the 1957 acquisition of C.C. Birchard \& Company - resulted in the company being renamed the Summy-Birchard Company; ${ }^{104}$ through a corporate restructuring in the 1970s, Summy-Birchard became a division of the music education firm Birchtree, Ltd., still held within the Sengstack family. ${ }^{105}$

By 1988, when the Sengstack family sold Birchtree to Warner Communications Inc. for a reported \$25 million, “Happy Birthday to You” was only the most famous of

\footnotetext{
${ }^{98}$ For people who grew up in a religious tradition, there will often be religious music - hymns, liturgical music, carols, and the like -- that fits this description as well.

${ }^{99}$ In his 1999 Ernest Bloch Lectures, "Music and Mind: Foundations of Cognitive Musicology," Professor David Huron dubbed "Happy Birthday to You"

the quintessential feminist work. Its composers remain unknown and uncelebrated; the work was created by the collaboration of two women rather than as an egotistic expression of one man. It is a thoroughly domestic work; Happy Birthday is performed in the kitchen or lunch room rather than in the concert hall. No other musical work has evoked so much spontaneous music-making. The work is domestic, amateur, and relationally oriented. Despite its extraordinary success, it remains undervalued as a musical creation.

http://music-cog.ohio-state.edu/Music220/Bloch.lectures/2.Origins.html.

${ }^{100}$ See "Summy, Clayton Frick" in The Cyclopedia of American Biography, Volume XVIII, p. 34 (1922).

${ }^{101}$ See id.

${ }^{102}$ See "Summy, Clayton Frick" in The Cyclopedia of American Biography, Volume XXIV, p. 421 (1935).

This entry, written after Summy's death, notes that "the best known publications of his house were

Abbott's 'Just for Today,' Gaynor's 'Slumber Boat,' and West's 'That Sweet Story of Old'; the Riley-

Gaynor operetta "The House That Jack Built," and the piano compositions, "Scherzando" by Beecher, "Praeludium” by Oldberg, "Juba Dance” by Bett, and "Preludes and Other Pieces” by N.Louise Wright." Id.

${ }^{103}$ See George Thomas Kurian, The Directory of American Book Publishing: From Founding Fathers to Today's Conglomerates 231 (1975).

${ }^{104}$ See id.

${ }^{105}$ See N. Smith, “Sisters Have a Hit, Year In and Year Out,” Los Angeles Times, April 5, 1985, p.1.
} 
50,000 Birchtree titles, about 1700 of which were active, including the entire Suzuki music instruction series. ${ }^{106}$ But those 50,000 titles were a drop in the bucket of Warner/Chappell Music, Inc., the publishing arm of Warner Music Group. Warner/Chappell now owns over one million musical compositions, and is along with EMI Music Publishing and Universal Music Publishing one of the world's three largest music publishers.

For the last two decades, the ownership of Warner/Chappell, and hence of "Happy Birthday to You," has been a matter of corporate dealmaking at the very highest level. In 1989, shortly after the acquisition of Birchtree, Warner Communications merged with Time, Inc to create Time Warner Inc., the world's largest media and entertainment conglomerate. ${ }^{107}$ A little over a decade later, Time Warner was itself purchased by America Online, creating AOL Time Warner. ${ }^{108}$ Two years after that merger, however, AOL was removed from the corporation's title, after the dot com collapse and a resulting $\$ 99$ billion loss declared on the corporation's income statement. ${ }^{109}$ Shortly thereafter, Time Warner sold its music publishing and recording operations, including Warner/Chappell, to a group of investors headed by Edgar Bronfman, Jr., who formed the Warner Music Group. ${ }^{10}$ Bronfman had aggressively led the Seagram Company, founded by his grandfather, into the entertainment business, before selling it to Vivendi in 2000 and briefly serving as the CEO of Vivendi Universal. ${ }^{111}$ Thus, while "Good Morning to All" was first published by a sole proprietor a little more than a century ago, "Happy Birthday to You" has by now become a small stream in the floods of revenue that are reshaped and redirected in the frequent restructuring of enormous corporations.

The law of copyright, and of copyright in music particularly, has also been fundamentally transformed in the twelve decades since "Good Morning to All" was first published in 1894. Those twelve decades span the three major eras of federal copyright law in the United States. Back in 1894, federal copyright protection was acquired by registering a work before it was published, as it had been since the first copyright act in 1790. A decade-and-a-half later, the Copyright Act of 1909 ushered in the second copyright era by dropping the registration requirement, and providing that publication of

\footnotetext{
${ }^{106}$ See Geraldine Fabrikant, “Put a Song in Your Portfolio: 'Happy Birthday’ Is for Sale,” The New York Times, October 20, 1988, p. A1; Geraldine Fabrikant, "The Media Business; Sound of a \$25 Million Deal: 'Happy Birthday' to Warner,” The New York Times, December 20, 1988, p. D1. David Sengstack has stated that the purchase price was actually \$15 million, not \$25 million, and that "Happy Birthday to You" and the Suzuki portfolio each accounted for about one-third of that price. See Bart Jackson, "Uncorking That Joyful Noise,” prepared for the March 26, 2003 edition of U.S. 1 Newspaper , available at http://www.princetoninfo.com/200303/30326p04.html.

${ }^{107}$ See Geraldine Fabrikant, “Time Inc. Gains Control of Warner Within Hours of Court Approval,” New York Times, July 25, 1989, p. A1.

${ }^{108}$ See Saul Hansell, "Internet Triumph: Surging Stock Enables a Onetime Upstart to Acquire a Giant,” New York Times, Jan. 11, 2001, p. A1.

${ }^{109}$ See Andrew Ross Sorkin \& David D. Kirkpatrick, “AOL Time Warner Drops the 'AOL,'” New York Times, Sep. 19, 2003, p. C4; David D. Kirkpatrick \& Jim Rutenberg, “AOL Reporting Further Losses; Turner Resigns,” New York Times, p. A1.

${ }^{110}$ See David D. Kirkpatrick, “Time Warner Sells Music Unit for \$2.6 Billion,” New York Times, Nov. 23, 2003, p. C1.

${ }^{111}$ See Rod McQueen, The Icarus Factor: The Rise and Fall of Edgar Bronfman (2004)
} 
a work with proper copyright notice was sufficient to obtain federal copyright protection. Seven decades after that, publication and notice themselves waned in importance, as federal copyright protection was extended to all original works fixed in a tangible medium of expression.

When "Good Morning to All" was first published, there was no public performance right for musical compositions. Composers had no legal right to prevent the use of their compositions in concerts or dramatic productions; they could only prevent others from making and selling printed sheet music. Although Congress added a right of public performance of music in $1897,{ }^{112}$ it took another two decades to develop an effective structure to enforce and collect revenues stemming from the licensing of that right. ASCAP was not founded until 1914, and it was not until 1917 that the Supreme Court laid the legal grounds for broad enforcement, by holding that a restaurant which did not charge admission could nonetheless be held liable for infringement of the public performance right if an orchestra it hired performed copyrighted music without permission. ${ }^{113}$ However, that was 90 years ago; in the meantime, public performance revenues have grown to form as much as $90 \%$ of the income of "Happy Birthday to You" in some years, and still account for a third of the song's annual income.

Thus, over their combined history, "Good Morning to All” and "Happy Birthday to You" have witnessed enormous changes in music distribution, the music publishing industry, and music copyright. Of course, it is the length of that history, and the continued success of Warner/Chappell in reaping substantial copyright licensing revenues from "Happy Birthday to You," that provides so much of the strength of the "Happy Birthday to You" copyright anecdote: if a song whose melody was published back in 1893 is protected until 2030, then copyright protection is too long, isn't it? That, however, assumes that "Happy Birthday to You" is still under copyright protection, and that the combined length of copyright of "Good Morning to All" and "Happy Birthday to You" are typical. It is to those two issues that we now turn.

\section{The Copyright Status of "Happy Birthday to You”}

Warner/Chappell Music, Inc., the publishing arm of Warner Music Group, claims that its subsidiary Summy-Birchard is the current sole owner of copyright in the song "Happy Birthday to You," and that the copyright in that song will expire in the year 2030 . $^{114}$ To evaluate that claim, we'll have to consider several different areas of copyright law, the trusts and estates law of three different states, and over a hundred pieces of evidence. As we will see below, before 1978, federal copyright protection had

\footnotetext{
${ }^{112}$ See Act of January 6, 1897, 29 Stat. 481.

${ }^{113}$ See Herbert v. Shanley Co. 242 U.S. 591 (1917) (reversing John Church Co. v. Hilliard Hotel Co., 221 F. 229 (2d Cir. 1915); John Church Co. v. Hilliard Hotel Co., 228 F. 1021 (2d Cir. 1915); and Herbert v. Shanley Co., 229 F. 340 (2d Cir. 1916)). The Herbert opinion, written by Justice Holmes, contains one of my favorite sentences in a copyright opinion: "The object is a repast in surroundings that to people having limited powers of conversation, or disliking the rival noise, give a luxurious pleasure not to be had from eating a silent meal.” Id. at 595.

${ }^{114}$ See

http://www.warnerchappell.com/wcm_2/song_search/song_detail/songview_2.jsp?esongId=126621000
} 
two separate terms: an original term of 28 years, and a renewal term that has been lengthened over time from 28 years, to 47 years, and then to 67 years. Add 28 plus 67, and you get 95 years, the current combined term of protection for works that obtained copyright before 1978. For that reason, the question of whether copyright in the song expires in 2030 turns out to be two questions: First, was federal copyright properly obtained 95 years before, in 1935? Second, was that copyright properly renewed in 1962? Assuming there is an affirmative answer to these two questions, the third question arises: is Summy-Birchard the current sole owner of copyright in the song? In general, answering the third question is a matter of tracing a chain of title from the author or authors of the song to Summy-Birchard. As we will see, however, the issue of who owned the song over time is not completely separate from the issue of whether the song is under copyright, since issues of authorization, notice, and the validity of filings under copyright law can turn on the identity of the copyright owner at relevant points in time.

As I have stated above, ${ }^{115}$ I will conclude that there are three principal weaknesses in the claim that "Happy Birthday to You" is still under copyright. The most serious of these weaknesses is probably the failure to obtain a renewal registration that covers the song. Rather than consider the weaknesses in order of severity, however, this Part of the Article will consider them in historical order, because explaining each issue requires familiarity with the previous history of the song. Thus, I will first consider whether the first authorized publication of "Happy Birthday to You" occurred in 1935, which will lead to an inquiry about who wrote the song. I will then consider whether the song was published with proper copyright notice. These first two issues both are relevant to whether an original 28-year term of copyright was properly obtained in 1935. Finally, I will consider whether copyright in the song was properly renewed before the end of that 28-year term in 1963.

A. Some Necessary Analytical Framework. It will help to lay out some basic concepts and legal doctrine at the very beginning.

1. Derivative Works. The first essential concept is the notion of a derivative work, and of the multiple "layers" of copyright that are involved with derivative works. The term "derivative work" only entered copyright law with the Copyright Act of 1976, ${ }^{116}$ but the idea has been around for a long time. ${ }^{117}$ Suppose that a melody, like the melody of "Good Morning to All," is composed and published in 1893. Later, some other author adds new words to that melody. That later author has borrowed enough of the earlier work (the melody) to amount to copyright infringement absent permission; at the same time, her addition (the new words) is substantial enough to constitute copyrightable matter itself. Those two elements are what make the amalgam of old music and new words a derivative work.

\footnotetext{
115 See supra pp. 2-3.

116 See 17 U.S.C. §101 (“derivative work”)

117 Act of March 4, 1909, 35 Stat. 1075, Chap. 320, §6 (referring to “abridgements, adaptations, arrangements, dramatizations, translations, or . . . works republished with new matter”).
} 
Further suppose that still later, yet another composer adds a piano arrangement to the amalgam of old music and newer words. Once again, that composer has both borrowed existing material, and added new material of his own. The resulting combination of melody, new words, and instrumental arrangement may be published as a single piece of sheet music, and we may think of it as one song. Copyright law, however, will treat that song as three separate works, and whether and for how long each of those works is under copyright are questions that must be answered independently with regard to each of the works.

In the case of "Happy Birthday to You," the versions of the song that are important to its copyright status do indeed have three layers. "Good Morning to You" was composed and published in 1893, and was under copyright until 1949. It consisted of a melody and an accompanying text. Because the melody was original, it was protected by copyright law whether or not it was accompanied by the text. At some point, someone added new words to the "Good Morning to All" melody: the familiar words of "Happy Birthday to You." The combination of those new words and that melody formed a new work, which has its own copyright status, independent of "Good Morning to All" and also independent of the text as spoken words. That combination is the crucial one in this story, because it is the valuable one -- no one wants to speak the words of the text without singing them, so the text by itself is not that important. In an attempt to keep things clear, I will refer to that combination as "the GMTA/HBTY combination" -- "GMTA" referring to the melody of "Good Morning to All," and "HBTY" referring to the words, namely the line "Happy Birthday to You” repeated three times, with "Happy Birthday Dear __ spliced in between the second and third repetition. With the phrase "GMTA/HBTY combination" so defined, we can refine the questions posed above. What we really want to know is whether federal copyright in the GMTA/HBTY combination was properly obtained in 1935; whether copyright in that combination was properly renewed in 1962; and whether Summy-Birchard is the current sole owner of that combination.

2. Copyright under the 1909 Act. The 1909 Act was in force from July 1, 1909 through December 31, 1977, a crucial period in the life of "Good Morning to All” and "Happy Birthday to You." The 1909 Act acknowledged that federal copyright law did not extend to unpublished works; ${ }^{118}$ under state law, a copyrightable work was protected perpetually so long as it remained unpublished. ${ }^{119}$ When the work was published with the authorization of the work's owner (the 1909 Act mostly used the term "proprietor" ${ }^{20}$ ), it became subject to federal copyright law. Federal copyright law granted an original term of protection of 28 years to those works that were published with

\footnotetext{
${ }^{118}$ Act of March 4, 1909, 35 Stat. 1075, Chap. 320, §2

${ }^{119}$ See, e.g., Wheaton v. Peters, 33 U.S. (8 Peters) 591, 657, 661 (1834).

${ }^{120}$ See, e.g., Act of March 4, 1909, 35 Stat. 1075, Chap. 320, $\S 8$ (providing “[t]hat the author or proprietor of any work made the subject of copyright by this Act, or his executors, administrators, or assigns, shall have copyright for such work under the conditions and for the terms specified in this Act”). The 1909 Act assumed that the author of a work was its initial owner; if the author assigned copyright in that work to someone, that assignee became the "proprietor" of copyright in the work. See, e.g., Mifflin v. R.H. White Co., 190 U.S. 260, 262 (1903) (construing the Copyright Act of 1831); Egner v. E.C. Schirmer Music Co., 139 F.2d 398, 399 ( $1^{\text {st }}$ Cir. 1943).
} 
proper copyright notice. ${ }^{121}$ Those works that were published without proper copyright notice entered the public domain - they were deprived of copyright protection under either federal or state law. ${ }^{122}$

If the work was published with proper copyright notice and thus received an original 28-year term of protection, it was eligible for an additional term of protection, called the renewal term. Under the original 1909 Act, the renewal term was also 28 years, ${ }^{123}$ but it was retroactively lengthened to 47 years in $1976,{ }^{124}$ and to 67 years in 1998. ${ }^{125}$ To obtain the renewal term, an application had to be filed with the Copyright Office during the last year of the original term. ${ }^{126}$ Note that under the 1909 Act, the filing of this application was the first interaction with the government required to maintain copyright protection in a work, since unpublished works were protected automatically under state law, and published works were protected under federal law for the original term - from the date of publication to a date 28 years later -- as long as they displayed a proper copyright notice.

B. The Original Term of Copyright: The 1935 Publications. Now we are in a position to approach the first question in the inquiry. When the Clayton F. Summy Company published sheet music of "Happy Birthday to You" in late 1934 and 1935, it published six different arrangements of the song. ${ }^{127}$ Five of the arrangements were credited to Preston Ware Orem, as an employee of the Clayton F. Summy Company; one of them was credited to a Mrs. R.R. Forman. ${ }^{128}$ Four of the arrangements were purely instrumental, and for some reason were actually titled "Happy Birthday" rather than "Happy Birthday to You." Because they did not include lyrics, they did not contain the GMTA/HBTY combination, and are therefore peripheral to our current inquiry. Two of the arrangements - one by Preston Ware Orem, and the one arrangement by Mrs. R.R. Forman - did include lyrics, and hence included the crucial GMTA/HBTY combination. Those two versions were published simultaneously on December 6, 1935, and the fact that the Forman arrangement bears a lower registration number than the Orem arrangement is undoubtedly fortuitous - probably a matter of which application the Copyright Office employee pulled out of the envelope first. ${ }^{129}$ Both versions bore the

\footnotetext{
${ }^{121}$ Act of March 4, 1909, 35 Stat. 1075, Chap. 320, §9 (copyright may be secured by publication with notice); id. §23 (providing for an original copyright term of 28 years). Proper notice consisted of the word "Copyright” (or the abbreviations "Copr." or “(”); the name of the copyright owner ("Clayton F. Summy Company," for example), and, in the case of printed literary, musical, or dramatic works, the year of publication ("1935," for example). Id. §18.

${ }^{122}$ See, e.g., National Comics Publications, Inc. v. Fawcett Publications, Inc., 191 F.2d 594, 598 (2d Cir. 1951).

${ }^{123}$ Act of March 4, 1909, 35 Stat. 1075, Chap. 320, §23.

${ }^{124}$ Act of October 19, 1976, P.L. No. 94-553, 90 Stat. 2541, §101 (amending Title 17 in total; see §§304(a), 304(b) as amended, 90 Stat. 2573-74).

${ }^{125}$ Sonny Bono Copyright Term Extension Act, P.L. No. 105-298, 112 Stat. 2827, §102(d) (Oct. 27, 1998).

${ }^{126}$ Act of March 4, 1909, 35 Stat. 1075, Chap. 320, §§23, 24.

${ }^{127}$ Six arrangements were registered, see infra $\mathrm{n}$. 168; on the cover of an early printing of one of the arrangements, all six arrangements are listed, see [BSM6].

${ }^{128}$ See infra n. 164.

${ }^{129}$ See infra n. 164.
} 
copyright notice “C 1935 Clayton F. Summy Company.”130 Was federal copyright thereby properly obtained in the GMTA/HBTY combination in 1935? That depends on two conditions, both of which have to be met. First, these publications must have been the first publications authorized by the copyright owner. Second, the notice must have been proper. Let's consider each of those conditions.

1. Authorization and Authorship. Was the 1935 publication the first publication authorized by an owner of copyright in the GMTA/HBTY combination? As far as we know, the only authorization that the Clayton F. Summy Company received was from Jessica Hill, the sister of Mildred and Patty Smith Hill. She agreed to allow the Clayton F. Summy Company to publish sheet music versions of "Happy Birthday to You" in return for five percent of the marked retail price of the first 700 copies sold and ten percent thereafter. ${ }^{131}$ She purported to do this as the owner of copyright in "Song Stories for the Kindergarten," the book in which "Good Morning to All" was first published. ${ }^{132}$ That might be a necessary condition of publishing an authorized version of the GMTA/HTBY combination, ${ }^{133}$ because in 1935, the melody of "Good Morning to All," one part of that combination, was still under copyright. It is not a sufficient condition, however, because "Song Stories for the Kindergarten" does not contain the crucial GMTA/HBTY combination (and if it had, of course, copyright protection for that combination would have ceased in 1949). Thus, we need to know whether Jessica Hill was both an owner of copyright in "Good Morning to All," and an owner of copyright in the GMTA/HBTY combination. ${ }^{134}$

State and federal copyright law both granted initial ownership of a work to the author of that work; ${ }^{135}$ all others needed to trace their ownership back to the author through some series of transfers. We know that Mildred and Patty Hill were the authors of "Good Morning to All." If they were also the authors of the GMTA/HBTY combination - an assumption that we will examine in some detail below - could Jessica Hill demonstrate a chain of title from them to her in both works? I conclude that she could. The details of ownership transfers are somewhat complex and tedious, and I have treated them fully in a memo posted online; I will provide a brief summary here.

\footnotetext{
${ }^{130}$ See [BSM5], [BSM6]

${ }^{131}$ The license also contained a provision that Jessica Hill was to receive one-half of any proceeds received by the Clayton F. Summy Company through the sale of mechanical reproduction or performance rights, the sale of sheet music in foreign countries, or through sublicensing. See Amended Complaint in Hill

Foundation v. Summy, pp. 7-8.

${ }^{132}$ See id.

${ }^{133}$ Footnote on copyright in derivative works - under 1976 Act, if no authorization from the author, then no copyright in the derivative work. Under 1909 Act, less clear, and of course, since federal copyright under 1909 Act did not reach creation of work, would need to consider from vantage point of publication.

${ }^{134}$ Note that we do not need to show that she was the sole owner of copyright in either work. Under the 1909 Act, each co-owner of a work had the power to assign her interest, or to license use of the work, without the approval of other co-owners. The same is true under the 1976 Act.

${ }^{135}$ Work for hire exception under the 1909 Act, and the Supreme Court case (Holmes) that slightly preceded it - note its application to the arrangements of HBTY -- but no suggestion that Jessica Hill was the employer of the author of GMTA or the GMTA/HBTY combination.
} 
As for “Good Morning to All," Jessica inherited an interest in the renewal term of copyright in the book "Song Stories for the Kindergarten," in which that song first appeared, from her sister Mildred upon Mildred's death in June of 1916. She inherited an additional share when her sister Mary died later that year, in September. Jessica herself filed a timely renewal term application for the book. Under prevailing precedent, Jessica thereby became the owner of legal title to the renewal term, but she held that title in trust for all of the other co-owners of renewal rights, whose interests were preserved by her timely application. ${ }^{136}$ The available evidence suggests that as of 1935, those co-owners included Patty Smith Hill, who would have owned a five-eighths interest; Jessica Hill herself, with a one-eighth interest; Archibald Anderson Hill, the son of Patty and Jessica's brother Archibald Alexander, also with a one-eighth interest; Louise Altenhofen, the mother-in-law of William Wallace Hill, another of Jessica and Patty's brothers, with three thirty-seconds interest; and Sophia A. Smith, William Wallace Hill's sister-in-law, with a one thirty-second interest. ${ }^{137}$ Because Jessica Hill owned legal title, she would have been in a position to authorize the Clayton F. Summy Company to use the "Good Morning to All" melody when publishing the Forman and Orem versions of "Happy Birthday to You.”

Assuming that Mildred and Patty Hill were joint authors of the GMTA/HBTY combination, or that Mildred Hill was the sole author of that combination, Jessica Hill would also have been a co-owner of copyright in the combination, and thus would have been capable of authorizing the Clayton F. Summy Company to use the combination when publishing the Forman and Orem arrangements. The legal details are somewhat different - common-law copyright in the unpublished work would have been treated as the personal property of the authors, rather than federal rights subject to the Copyright Act - but the distribution of ownership in those rights as of 1935 would have turned out the same.

Because Jessica could have authorized the publication of the GMTA/HBTY combination if but only if Mildred or Patty wrote it, the question of authorization brings us face to face with the most difficult question of fact in this inquiry: who was the author of the GMTA/HBTY combination? Interestingly enough, the only statement by the current putative owner of copyright in the combination completely avoids the issue through use of the passive voice. The description of "Happy Birthday to You" on the Warner/Chappell website states: "The melody was written in 1893 by two school teaching sisters who wrote it as a classroom greeting called 'Good Morning To You.' The birthday lyric was added later."138 Putting that surprising evasion to one side, let us review the available evidence.

\footnotetext{
${ }^{136}$ See 3 Melville B. Nimmer \& David Nimmer, Nimmer on Copyright § 9.05[E].

${ }^{137}$ As we will see, in 1939 the Clayton F. Summy Company managed to have the estate of William Wallace Hill reopened, and to purchase his interest in "Good Morning to All" at a private sale approved by the Cook County Probate Court. See infra p. xx.

${ }^{138} \mathrm{See}$

http://www.warnerchappell.com/wcm_2/song_search/song_detail/songview_2.jsp?menu_status=songsearc h\&esongId $=126621000$
} 
a. The Myth of a Court Ruling. Perhaps the most enduring myth in published accounts of "Happy Birthday to You" -- repeated dozens of times -- is that a court awarded ownership of the song to Mildred and Patty Smith Hill in 1934 or $1935 .^{139}$ As far as I can tell, that is complete fabrication. Unless my research missed something, ${ }^{140}$ the song, or its predecessor "Good Morning to All," has been involved in litigation four times: in Hill v. Harris, filed in 1934; ${ }^{141}$ in Hill v. Federal Broadcasting Corporation, ${ }^{142}$ filed in 1935; in Hill Foundation v. Clayton F. Summy Co., ${ }^{143}$ filed in 1942; and Hill Foundation v. Postal Telegraph-Cable Company, ${ }^{144}$ filed in 1943 . None of those cases ever proceeded to final judgment, nor did the court in any of those cases issue any ruling about authorship or copyright ownership. ${ }^{145}$ Indeed, in 1981 David Sengstack, president of Summy/Birchard at the time, was quoted as acknowledging that Jessica Hill "lost [Hill $v$. Harris] on a technicality." 146 Thus, no judge or jury has ever passed on the issue of who wrote the GMTA/HBTY combination. We are left to sift through the sparse evidence ourselves, and to consider whether that evidence would be sufficient to convince a fact finder that Patty Smith Hill or Mildred Hill or both were the authors.

\footnotetext{
${ }^{139}$ See, e.g., Nancy Vendrely, “Songs Nobody Can Deny,” Fort Wayne Journal Gazette, December 30, 2004, p. 1D; "Straight Dope,” Memphis Flyer, October 25, 2000, p. 50; “"Happy Birthday' Writers Honored - Louisville to Name Parking Lot for Pair," Lexington Herald-Leader, August 29, 2002, p. B7; Frank Allen, "How the World's Most Popular Song Was Born," Express, June 20, 2003, p. 17; "Two Sisters With Little To Celebrate," Alameda Times-Star, May 30, 2006; J. Byron, "Exposing the Happy Birthday story," http://www.kuro5hin.org/story/2003/7/5/112441/6280 ("The Hill family sued for infringement and won") .

${ }^{140}$ In addition to examining dozens of secondary sources for specific references to litigation, I examined case indices at the National Archives and Records Administration, Northeast Region in New York City, covering cases in the United States District Court for the Southern District of New York, and at the National Archives and Records Administration, Great Lakes Region in Chicago, covering cases in the United States District Court for the Northern District of Illinois. New York City was a likely venue for litigation because of its importance as a center of music publishing and distribution; because Patty and Jessica Hill lived there from before 1910 to their respective deaths in 1946 and 1951; because the Hill Foundation, Inc., a trust set up by Patty and Jessica, was headquartered there; and because the Clayton F. Summy Company maintained an office there for some time. Chicago was another likely venue because the Clayton F. Summy Company, later Summy-Birchard, was headquartered in Chicago or a Chicago suburb from its founding in the 1890s through the late 1970s. It is conceivable that there was litigation elsewhere in the United States - only quite recently has there been an attempt to set up a central index for all federal court litigation, see [PACER] - but I have found no trace of it.

${ }^{141}$ See [HVH 2] (complaint in Jessica Hill v. Sam H. Harris, et al., Equity No. 78-350 (S.D.N.Y., complaint filed August 14, 1934)).

${ }^{142}$ See [HVFB 2] (complaint in Jessica Hill v. Federal Broadcasting Corporation, et al., Equity No. 79-312 (S.D.N.Y., complaint filed January 21, 1935)).

${ }^{143}$ See [HVFS 1a] (complaint in The Hill Foundation, Inc. v. Clayton F. Summy Co., Civil No. 19-377 (S.D.N.Y., complaint filed October 15, 1942)).

${ }^{144}$ See [HFVPT 2] (complaint in The Hill Foundation, Inc. v. Postal Telegraph-Cable Company, Civil No. 20-439 (S.D.N.Y., complaint filed March 2, 1943)).

${ }^{145}$ Even if they had gone to judgment, it is unlikely that the judgment would have necessitated any findings about the GMTA/HBTY combination. In the 1930s and 1940s, "Good Morning to All” was still under copyright, and the plaintiffs were suing for infringement of the "Good Morning to All" melody; that infringement could be proven without considering the issue of ownership of copyright in the combination of melody and words.

${ }^{146}$ Julie Salamon, “Happy Birthday - Sing it Out, But Prepare to Pay,” Louisville Courier-Journal, June 29, 1981, p. B5 (reprinted from the Wall Street Journal).
} 
b. Evidence of Authorship. Available evidence that bears on the issue of authorship of the GMTA/HBTY combination includes the 1935 deposition testimony of Patty Smith and Jessica Hill in Hill v. Harris; the many published versions of the GMTA/HTBY combination throughout the 1910s and 1920s, unauthorized by any member of the Hill family; the versions of "Happy Birthday to You" published in 1934 and 1935 by the Clayton F. Summy Company, and the copyright registration applications and certificates for those versions; subsequent versions published by the Summy Company and its successors; pleadings in Hill Foundation v. Clayton F. Summy Company in 1942; and various popular accounts of the genesis of the lyrics. The reader can make his or her own evaluation, but I think that the evidence supporting a claim of authorship of the combination by Patty or Mildred is quite weak.

i. The Patty Smith and Jessica Hill Depositions. In August of 1934, Jessica Hill sued Sam H. Harris, the legendary Broadway producer; his production company, Sam H. Harris Theatrical Enterprises Inc.; the composer Irving Berlin; and playwright Moss Hart. Harris had produced a Broadway musical called "As Thousands Cheer," written by Berlin and Hart, which had a successful Broadway run of 403 performances. ${ }^{147}$ Berlin wrote a number of classic originals for the musical, including "Easter Parade" and "Heat Wave," but the king of American occasional songwriting did not manage to compose an original song for a scene celebrating John D. Rockefeller's birthday. Instead, that scene featured cast members singing "Happy Birthday to You," to the tune of "Good Morning to All." Jessica Hill's complaint was that the performance of that melody violated the copyright in "Good Morning to All." At that point, no version of the GMTA/HBTY combination had been registered at the Copyright Office, and so no lawsuit could have been brought in federal court regarding infringement of that combination. ${ }^{148}$ Whether or not that was the reason Jessica Hill confined herself to alleging infringement of "Good Morning to All," that is what she did. The lawsuit was eventually dismissed in 1938 for lack of prosecution. ${ }^{149}$

Hill v. Harris produced no substantive rulings of any kind. The only matters on which the court ruled on were the addition of Berlin, Hart, and Harris Theatrical Enterprises as defendants (the case was originally filed against Harris alone), and a request to compel defendants to answer interrogatories and produce certain documents. But the litigation was active for long enough for depositions to be taken of Patty Smith

\footnotetext{
${ }^{147}$ See [HVH 9], p. 4.

${ }^{148}$ See Hurn v. Oursler, 289 U.S. 238 (1933) (holding that a federal court did not have jurisdiction to hear a state unfair competition claim regarding an uncopyrighted version of a play, since that cause of action was independent of a federal copyright claim asserted by plaintiff).

149 This dismissal is one of the great mysteries of the history of "Happy Birthday to You." It seems quite clear that "As Thousands Cheer" did use the melody of "Good Morning to All," and that there would have been no good defense to the charge of infringement. Conceivably, there was a settlement; but under normal circumstances, a settling defendant would insist on a dismissal on the merits, not just a dismissal for lack of prosecution. Moreover, according to a pleading in the 1942-44 litigation between The Hill Foundation, Inc. and the Clayton F. Summy Company, the Summy Company promised that it was going to try to reopen the Hill v. Harris case in 1939, which suggests that litigation in Hill v. Harris really had just ceased to move forward, rather than being settled. See [HFVS 5], p. 3.
} 
and Jessica Hill, and both of those include passages about the GMTA/HBTY combination. Here is an excerpt from the deposition of Patty Hill:

A. . . while only the words "Good Morning to All" were put in the book we used it for "Good-bye to you”, "Happy Journey to You”, "Happy Christmas to You” and "Happy New Year to You”, Happy Vacation to You” and so forth and so on.

Q. Did you also use the words "Happy Birthday to You”.

A. We certainly did with every birthday celebration in the school.

Q. Did you write the words for this particular tune of "Good Morning To All,” Miss Hill?

A. I did.

Q. Had you at that time also written many other verses in conjunction with the words which appear in the edition of "Song Stories for the Kindergarten”, published in 1893.

A. Yes, we were writing them practically every day. ${ }^{150}$

What can we gather from this passage? If we credit Patty Hill's testimony, we have evidence that the GMTA/HBTY combination was created very early on, perhaps even before the publication of "Song Stories for the Kindergarten" in 1893. But it is quite curious how this passage, and the entire deposition, stops short of any assertion that Patty Smith Hill wrote the "Happy Birthday to You” lyrics. Patty Smith Hill testifies (1) that she wrote the words for the published version of "Good Morning to All" (a single verse, which did not include "Happy Birthday to You"; (2) that she, or she and her sister Mildred, wrote "many other verses" to the "Good Morning to All" tune; and (3) that the "Happy Birthday to You” words were "used" at school birthday celebrations. She does not, however, assert that she or her sister wrote the "Happy Birthday to You" words, or combined them with the tune of "Good Morning to All."

In response to the question whether she remembered singing many lyrics to the tune of "Good Morning to All," Jessica Hill testified in her deposition: "I remember particularly 'Good Morning to You' and 'Happy Birthday to You'. Those are the two that impressed me most. I may have sung, you know, those others, but those are the two that I remember." "151 This testimony also stops short of any assertion of authorship. Thus, the depositions provide evidence of the date that the GMTA/HBTY combination was created, but don't provide evidence of who was responsible for its creation.

${ }^{150}$ [HVH 12] Deposition De Bene Esse 7-8 in Hill v. Harris, No. E 78-350, United States District Court for the Southern District of New York (Examination of Miss Patty S. Hill by Mr. Malcolm B. Stark).

${ }^{151}$ [HVH 12] Deposition De Bene Esse 31 in Hill v. Harris, No. E 78-350, United States District Court for the Southern District of New York (Examination of Miss Jessica M. Hill by Mr. Malcolm B. Stark). 
ii. Earlier Published Versions. The tune of "Good Morning to All" and the lyrics of "Happy Birthday to You" were published together many times before 1935 . The first book including the combination that bears a date of publication is "The Beginners' Book of Songs," published by the Cable Company, a piano manufacturer, in $1912 .^{152}$ The Cable Company evidently printed many similar songbooks in cheap paperback editions with overlapping contents, and "Good Morning to All” with "Happy Birthday" as alternate lyrics is also found in the undated tenth edition of the Cable Company's "The One Hundred and One Best Songs,"153 and was likely found in earlier and later editions as well. The GMTA/HBTY combination also appears in "The Golden Book of Favorite Songs," compiled and edited by N.H. Aitch, and published by the Hall \& McCreary Company in 1915; ${ }^{154}$ "Children's Praise and Worship," compiled and edited by A.L. Byers, Bessie L. Bynum and Anna E. Koglin and published by the Warner Press in 1928; ${ }^{155}$ and several hymnals compiled and edited by Robert H. Coleman, ${ }^{156}$ including "Harvest Hymns," published by the Baptist Sunday School Board in 1924, ${ }^{157}$ and "The American Hymnal,” published by Robert H. Coleman himself in $1933 .{ }^{158}$

152 [S51] The Beginners' Book of Songs (Chicago: Cable Company, 1912).

153 [S53] The Cable Company, pub., The One Hundred and One Best Songs 23 (undated $10^{\text {th }}$ edition)

154 [S52] N,H, Aitch, ed., The Golden Book of Favorite Songs 81 (Chicago: Hall \& McCreary, 1915).

${ }^{155}$ [S54] A.L. Byers, Bessie L. Bynum and Anna E. Koglin, eds., Children's Praise and Worship, Song No. 220 (Anderson, Indiana: The Warner Press 1928).

${ }^{156}$ One popular variation on the legend of "Happy Birthday to You" litigation is that Patty and Jessica Hill sued Robert H. Coleman and "proved that they owned the melody." See, e.g., Lindsey Williams, "Birthday Song Best, Charlotte Sun, November 18, 2001; Louis S. Schafer, "Birthday Tradition Result of Musical Theft," Back Home in Kentucky, July/August 2004, p. 23, 24; http://www.lausd.k12.ca.us/Woodland_Hills_EL/Patter_1203.htm. That story has spread around the world, to places like Germany, France, and China. See Thomas Hoeren, "Happy birthday to you urheberrechtliche Fragen rund um ein Geburtstagsständchen,"http://www.unimuenster.de/Jura.itm/hoeren/INHALTE/publikationen/Happy_Birthday.pdf ; Joe Silk, "Chantez 'Happy Birthday'et risqué de . . . vous faire poursuivre,”Jurizone, October 12, 2007, http://www.jurizone.com/tribune.php?id=25;

http://www.storychina.cn/main2.asp?id=2278\&tablename=sitesearch\&lei=\%E9\%91\%BB\%E8\%BE\%AB\% EE\%87\%A2\%E9\%8F\%81\%E5\%91\%AC\%E7\%B0\%A8\&leiID=7;

http://i.mop.com/zzzhanglisha/blog/2007/08/11/4665940.html . Robert Coleman was an important religious music publisher in the first three decades of the twentieth century, and was generally meticulous about copyright matters. See J. Michael Raley, “'Sing Unto the Lord a New Song': Robert H. Coleman's Gospel Song Books and Hymnals (1909-1939) and Their Impact on Southern Baptist Hymnody” in J. Michael Raley \& Deborah Carlton Loftis, eds., Minds and Hearts in Praise of God : Hymns and Essays in Church Music in Honor of Hugh T. McElrath (2006). A collection of Coleman's papers, which includes many pieces of correspondence about copyright licensing, is housed at the Southwestern Baptist Theological Seminary. Ms. Emily G. Blaising, a member of the library staff there, was kind enough to carefully examine those papers for any reference to the songs "Good Morning to All" or "Happy Birthday to You," or to Patty or Jessica Hill or the Clayton F. Summy Company, and she found nothing. Given the impeccable claim of Patty and Jessica Hill to ownership of copyright in "Good Morning to All," it seems almost certain that Coleman, if approached by the Hill sisters, would have voluntarily ceased publishing the song and settled the dispute rather than going to the expense of defending a lawsuit. If the matter did end up being litigated all the way to final judgment, it would be surprising that Coleman's papers contain no mention of such litigation.

${ }^{157}$ Robert H. Coleman, comp. and ed., Harvest Hymns (Nashville: Baptist Sunday School Board, 1924).

${ }^{158}$ Robert H. Coleman, comp. and ed., The American Hymnal (1933). The versions in "The Beginners' Book of Songs" and "The Golden Book of Favorite Songs" have "Happy Birthday to You" (and "Good- 
These books certainly provide good evidence that the GMTA/HBTY combination was composed before 1912. Some have suggested that because the combination was published in these books without copyright notice, or at least without any copyright notice that included the names of Mildred or Patty Smith Hill or any assignee of theirs, that any copyright in the combination was forfeited. ${ }^{159}$ Recall, however, that for publication without notice to work a forfeiture of copyright, that publication must be authorized by the owner of common-law copyright in the unpublished work. None of the books contains any attribution of "Good Morning to All” or the GMTA/HBTY combination to any composer or author, though all of the books include author and composer credit for many of the other songs included in the books. That suggests that the compilers of the collections assumed that "Good Morning to All" and the GMTA/HBTY combination were without known authors and were not under copyright, which in turn suggests that they did not seek authorization to publish from any member of the Hill family, or any other author of the GMTA/HBTY combination. Thus, all of the publications were likely unauthorized, and have no bearing on the issue whether federal copyright was obtained or forfeited in the GMTA/HBTY combination.

Other doctrines that might be asserted as defenses to copyright infringement would not seem to apply here. Courts have recognized the possibility that a copyright might be abandoned, but there is strong authority that abandonment requires an overt act demonstrating an intent to abandon - inaction is not enough. ${ }^{160}$ Even the few courts that may not have required an overt act still seem to require proof that the copyright owner knew of the infringing activity and did not take action. ${ }^{161}$ Patty Smith Hill's deposition testimony suggests she knew that "Happy Birthday to You” was being sung at some public events, ${ }^{162}$ but it does not indicate she knew that copies of it had been published. ${ }^{163}$

Bye to You") written as alternative titles underneath the main title "Good Morning to You," rather than having the lyrics written out in full underneath the staves for the melody. The versions in the Coleman hymnals have the lyrics written out under the staves as a second verse to "Good Morning to You"; the third line of the lyrics does not leave a space to insert the name of the person whose birthday is being celebrated after "dear," but instead reads "happy birthday, dear children." The version in the 1928 "Children's Praise and Worship," however, presents "Happy Birthday to You" as a separate song ("Good Morning to All” is also included in the book, several pages later, with three verses that do not include "Happy Birthday to You”), and the lyrics are written exactly as they are customarily sung today, with blank spaces after the word "dear" to insert the name of the person whose birthday is being celebrated.

${ }^{159}$ See "Exposing the Happy Birthday Story,” http://www.kuro5hin.org/story/2003/7/5/112441/6280 (reporting the claim of Bob Katzmarek that "Happy Birthday to You" is in the public domain because it was published without copyright notice on a number of occasions).

${ }^{160}$ See, e.g., Lottie Joplin Thomas Trust v. Crown Publishers, Inc., 456 F. Supp. 531 (S.D.N.Y. 1977), aff'd, 592 F.2d 651 (2d Cir. 1978); Hampton v. Paramount Pictures Corp., 279 F.2d 100 (9 $9^{\text {th }}$ Cir.), cert. denied, 364 U.S. 882 (1960); Nimmer on Copyright §13.06.

${ }^{161}$ See, e.g., Stuff v. E.C. Publications, Inc., 342 F.2d 143 (2d Cir. 1965) (noting that the District Court found that the copyright owner had been "most derelict in preventing others from infringing his copyright," which supported an inference "that the copyright owner authorized or acquiesced in the wide circulation of the copies without notice.").

${ }^{162}$ See [HVH 12], pp. 15-16. The litigation focused on infringement of the melody of "Good Morning to All," which was the federally copyrighted song at issue, so neither the attorney asking questions nor Patty Smith Hill draw a clear line between performances of "Good Morning to All" with the original lyrics, and performances of the GMTA/HBTY combination. Patty Smith Hill does state that she "read in the 
There is a tantalizing sentence in an article published in Time magazine on August 27, 1934 which could conceivably be construed as a paraphrase of an overt statement of abandonment. In a report on the Hill v. Harris case, the article notes that the suit alleges infringement of the melody, but not the "happy birthday" words, and then states: "Lyricist Patty Hill, who will share in the damages, if any, had no complaint to make on the use of the words because she long ago resigned herself to the fact that her ditty had become common property of the nation." 164 Yet since this doesn't even pretend to be a direct quote, its evidentiary value is limited, and, in any event, Patty Hill was not the sole owner of copyright in the GMTA/HBTY combination in 1934, and a statement by her alone could not have resulted in abandonment of the interests of the other owners.

The defense of laches is even less likely to have any application in these circumstances. While recognized in some circuits, ${ }^{165}$ laches can only be raised by particular defendants against whom a copyright owner has unreasonably delayed taking action, and usually only bars recovery of damages for previous acts of infringement, not injunctive relief against future infringement. ${ }^{166}$ Part IV of this Article will consider whether the increases in the term of copyright protection may necessitate new title clearing doctrines; but the truth is that such doctrines would indeed be new.

iii. The 1934-35 Registrations and Publications. Although it was not necessary to register a work to obtain the original term of copyright protection under the 1909 Act, there were still advantages to registration. ${ }^{167}$ One of those advantages was the evidentiary weight of the certificates of registration issued by the Copyright Office. Section 55 of the Copyright Act of 1909 provides that a registration certificate "shall be admitted in any court as prima facie evidence of the facts stated therein."168 The Clayton F. Summy Company registered all six versions of "Happy Birthday to You" that it

newspaper that on President Roosevelt's birthday it was sung," id., which was clearly a performance of the GMTA/HBTY combination.

${ }^{163}$ Patty Smith Hill testifies that "if a publisher would write me and say that somebody wished to use this song in China or Japan and said he was willing if credit was given at the bottom of the page for the publishers and authors, I was more than willing," [HVH 12] p. 17, but it is not clear at all that those uses would have included the "Happy Birthday to You" lyrics. In response to the question "Did you or did you not come across song books published by publishers other than by Clayton F. Summy which contained the song "Good Morning to All," Hill answers "With my permission, no - I should think you would have to refer that to the publishers because they kept a very close track on it personally so that I can't tell you that." [HVH 12], p. 18.

${ }^{164}$ Time, August 27, 1934.

${ }^{165}$ Compare Danjaq LLC v. Sony Corp., 263 F.3d $942\left(9^{\text {th }}\right.$ Cir. 2001) (recognizing a laches defense against copyright infringement) with Lyons Partnership, L.P. v. Morris Costumes, Inc., 243 F.2d 789, 797 (4 ${ }^{\text {th }}$ Cir. 2001) (holding that there is no laches defense to copyright infringement).

${ }^{166}$ See, e.g., Hayden v. Chalfant Press, Inc., 177 F. Supp. 303 (S.D. Cal. 1959); aff'd, 281 F.2d 543 (9 $9^{\text {th }}$ Cir. 1960); Nimmer on Copyright §12.06[B][4].

${ }^{167}$ Recall that a work protected under federal copyright must be registered before a lawsuit can be filed alleging infringement of that work. A work also must be registered before documents concerning transactions involving that work can be recorded.

${ }^{168}$ Act of March 4, 1909, 35 Stat. 1075, Chap. 320, §55. The Copyright Act of 1976 retains this presumption in slightly modified form. See 17 U.S.C. §410(c) ("In any judicial proceedings the certificate of a registration made before or within five years after first publication of the work shall constitute prima facie evidence of the validity of the copyright and of the facts stated in the certificate.”) 
published in 1934 and 1935, including the two versions with lyrics. Those certificates contain the names of Mildred and Patty Smith Hill as authors of "Happy Birthday to You."169 Does section 55 render those attributions admissible evidence of authorship, placing the burden on anyone who wishes to challenge that authorship to come forward with evidence to the contrary?

The section 55 presumption should not apply here, because the registration applications filed by the Clayton F. Summy Company nowhere contain the names of Mildred and Patty Smith Hill, and do not claim copyright in the GMTA/HBTY combination. The Clayton F. Summy Company filed each of the six registration applications on a form specifically intended for a "Republished Musical Composition With New Copyright Matter" - what we would in modern jargon call a derivative work. On the line of the applications asking the applicant to identify the "Author of new copyright matter," one of two names appears. On five of the applications, including one of the applications for the two versions containing lyrics, the entry on that line is "Preston Ware Orem, employed for hire by the Clayton F. Summy Company.” On the remaining application, for the other version with lyrics, the entry is "Mrs. R.R. Forman."170

The two registration applications for versions with text were filed simultaneously, on December 6, $1935 .^{171}$ In the application for the version that issued as registration number E pub 51988, the Summy Company states that it claims copyright in an arrangement "for unison chorus with revised text." Although "revised text" could in

\footnotetext{
${ }^{169}$ Registration certificates were issued to the applicants, but the registration records kept by the Copyright Office consist of entries in a registration book rather than individual certificates. It is the books which form the public record, and to which I had access. In theory, the information entered into the books should be the same as the information entered on the certificate. See U.S. Copyright Registration Class E pub 45655 (Date of publication December 27, 1934; Copyright Office received two copies December 31, 1934) ("Happy Birthday! March. By Mildred J. Hill and Patty S. Hill. Arranged by Preston Ware Orem, of U.S., employed for hire by Clayton F. Summy Co. Piano,”); U.S. Copyright Registration Class E pub 46661 (Date of publication February 15, 1935; Copyright Office received two copies February 19, 1935) ("Happy Birthday. March. By Mildred J. Hill. Arranged by Preston Ware Orem, employed for hire by Clayton F. Summy Co, of U.S. Copyright is claimed on arr. for four hands at one piano"); U.S. Copyright Registration Class E pub 47439 (Date of publication April 3, 1935; Copyright Office received two copies April 6, 1935) ("Happy Birthday. March. By Mildred J. Hill and Patty S. Hill. Arranged by Preston Ware Orem (employed for hire by Clayton Summy Co.) of U.S. For two pianos. Copyright is claimed on arrangement of second piano part”); U.S. Copyright Registration Class E 47440 (Date of publication April 3, 1935; Copyright Office received two copies April 6, 1935) ("Happy Birthday! March. By Mildred J. Hill and Patty S. Hill. Arranged by Preston Ware Orem (employed for hire by Clayton F. Summy Co.), of U.S. For piano, six hands. Copyright is claimed on arrgt.”); U.S. Copyright Registration Class E pub 51988 (Date of publication December 6, 1935; Copyright Office received two copies December 9, 1935) ("Happy Birthday to You! Unison Song. By Mildred J. Hill. Arr. By Mrs. R.R. Forman, of U.S. Copyright is claimed on arr. For unison chorus and revised text”); U.S. Copyright Registration Class E pub 51990 (Date of publication December 6, 1935; Copyright Office received two copies December 9, 1935) ("Happy Birthday to You! By Mildred J. Hill. Preston Ware Orem (employed for hire by Clayton F. Summy Co.), of U.S. Piano solo with words. Copyright is claimed on arr. as easy piano solo, with text”). ${ }^{170}$ As we will see below, see infra, when it came time to renew these arrangements, the Clayton F. Summy Company, which by then had become Summy-Birchard, asserted that both of them were works for hire.

${ }^{171}$ Every account that I've ever seen mentions the Preston Ware Orem arrangement, but not the Mrs. R.R. Forman arrangement. I can only assume this is because everyone has relied on a secondary source, without examining the Copyright Office records.
} 
theory refer to the addition of the "Happy Birthday to You" lyrics to "Good Morning to All” - the crucial GMTA/HBTY combination - the revision in question is undoubtedly later and more modest. No one has ever claimed that the identified author of new copyright matter, Mrs. R.R. Forman, is responsible for the GMTA/HBTY combination. On the deposit copy of sheet music itself, her credit reads only "Arr. By Mrs. R.R. Forman"; she is given no credit for the words. ${ }^{172}$ Moreover, if we believe the deposition testimony of Jessica and Patty Smith Hill, the combination was accomplished some 40 years earlier, either before or shortly after "Song Stories for the Kindergarten" was published. Although I have not been able to find out much about Mrs. R.R. Forman, she was a composer active in the mid-1920s to mid-1930s, and there is no indication that she had any exposure to "Good Morning to All" as early as the mid-1890s, or even the 1910s when the first versions of the combination were published. ${ }^{173}$ The Mrs. R.R. Forman version does add a second verse, with the first two lines changed to "May your birthday be bright, full of cheer and delight." That is undoubtedly the "revised text" claimed in the application, and it is commercially insignificant, because no one uses it.

In the application for the other version with text, which issued as registration $\mathrm{E}$ pub 51990, the Clayton F. Summy Company states that it claims copyright in an "Arrangement as easy piano solo, with text." Although there is some ambiguity in this description, it seems clear in context that this is not claiming the GMTA/HBTY combination either, but only the addition of an easy piano solo arrangement. The only author of new copyright matter identified is Preston Ware Orem, and the GMTA/HBTY combination could not have been original to him, for the same reason that it could not have been original to Mrs. R.R. Forman. There is no evidence that Preston Ware Orem was involved with "Happy Birthday to You” before the mid-1930s. As an employee (and for some period including mid-1934, Vice-President ${ }^{174}$ ) of the Clayton F. Summy Company, he composed musical arrangements of many songs that he did not write, and there is no reason to think that he had any different relationship to "Happy Birthday To You." 175

The Copyright Act of 1909 required claimants to deposit two copies of the work that they sought to register along with the registration application. The names of Mildred J. and Patty S. Hill undoubtedly made their way onto the registration certificates because the copyright examiner copied them from the deposited copies. There is a very good argument that the evidentiary weight that the 1909 Act gives to facts stated in the

\footnotetext{
172 See [S 101].

173 See supra p. xx.

${ }^{174}$ See Elizabeth Newman v. Clayton F. Summy Company, Transcript of Proceedings, p. 93 (testimony of Mildred Sengstack).

${ }^{175}$ For other Preston Ware Orem arrangements commissioned by the Clayton F. Summy Co., see, e.g., “Little Christmas Fantasy, on Favorite Tunes,” U.S. Copyright Registration E pub 44268 (publication date Oct. 16, 1934), U.S. Copyright Registration R 289112 (renewed January 18, 1962); "None But The Lonely Heart,” U.S. Copyright Registration E pub 44159 (publication date October 8, 1934), U.S. Copyright Registration R 289110 (renewed January 18, 1962). For a brief and unsupported assertion that Preston Ware Orem wrote the "Happy Birthday to You” lyrics, see http://en.wikipedia.org/w/index.php?title=Happy_Birthday_to_You\&oldid=137806020 [add biographical background on Preston Ware Orem]
} 
registration certificate only applies to those facts stated in the application for registration. After all, what the Copyright Office is actually registering is a claim to copyright, and the limits of the claim are set by the application. Since the authorship of the GMTA/HBTY combination, and Mildred and Patty Hill's role in that authorship, formed no part of the claim submitted by the Clayton F. Summy Company, the appearance of the names of Mildred J. and Patty S. Hill in the registration certificate should not be given any evidentiary weight at all.

Of course, whether or not the appearance of the Hills' names in the registration certificate should trigger the section 55 presumption, the names did appear on the sheet music that was deposited in the Copyright Office and that was publicly distributed. Do those appearances provide evidence of authorship? I'm not sure that they provide any evidence of authorship of the GMTA/HBTY combination at all, but if they do, it is exceedingly weak. None of the versions that were registered in 1934 and 1935 introduces the Hill sisters' names with any phrase like "Words and Music By" that would explicitly claim authorship of the lyrics; rather, their names simply appear underneath and to the right of the song title. Since Mildred and Patty Smith Hill were incontrovertibly the authors of "Good Morning to All," the melody of which became part of the song "Happy Birthday to You," of course they would be credited for that melody. The only slim inference left is that to be drawn from the lack of a credit to another author for the lyrics.

iv. Later Published Versions. From 1935 onwards, the Clayton F. Summy Company and its successors and foreign licensees published many different editions of "Happy Birthday to You." I have been able to locate about fifteen of those editions. A few interesting observations can be made about them. Until 1950, none of the six editions with words - including the original Forman and Orem arrangements published in 1935 - credit Patty Smith Hill. Mildred Hill is credited as the sole author, and her name is always placed on the right-hand side above the staffs - the traditional place for the composer of the music, not the author of the lyrics. ${ }^{176}$ Even after one edition is published on 1950 which credits both Mildred and Patty Hill, ${ }^{177}$ five more editions are published throughout the 1950s that credit only Mildred Hill. ${ }^{178}$ One of them - a printing of the "Twice 55 Community Song Book, published by the C.C. Birchard Company in 1957 and exclusively sold by the Clayton F. Summy Company, shortly before the two companies merged - actually explicitly credits the words to "TRADITIONAL," while crediting the music to Mildred J. Hill. ${ }^{179}$ And even the 1950 edition that credits both Mildred and Patty just lists their names; it does not explicitly claim that they wrote the words. ${ }^{180}$ Only later, probably during the 1960s but in any event before 1969, is an edition published that explicitly credits "Words and Music by Patty S. and Mildred J. Hill.,181

\footnotetext{
${ }^{176}$ See [S 101]; [S 102]; [S 104]; [S 105]; [S 106].

177 See [S 107].

${ }^{178}$ See [S 108]; [S 109]; [S 110]; [S 111]; [S 112].

${ }^{179}$ See [S 111].

${ }^{180}$ See [S 107].

${ }^{181}$ See [S 115].
} 
This publishing history suggests that it took a very long time for the Clayton F. Summy Company and its successors to take and publicly assert Summy-Birchard's current position that Mildred and Patty Hill were jointly responsible for the GMTA/HBTY combination. There is no assertion that Patty Hill is involved with the song at all until after her death, and after the copyright term of "Good Morning to All" had come to an end; there is no explicit assertion that Mildred and Patty are responsible for the words for many years after that. The inconsistency in crediting, and the long delay before any explicit claim is made to authorship of the words, certainly does not lend any additional strength to that claim.

v. Statements in the Hill Foundation Complaints. In 1942, Patty and Jessica Hill created a corporation called The Hill Foundation, Inc. and assigned to it their interests in "Good Morning to All." The Hill Foundation then filed two lawsuits regarding the song. First, it sued the Clayton F. Summy Company, alleging that the Summy Company had collected more than \$5000 in royalties through licensing the song for use in motion pictures and plays, and seeking a share of those royalties. ${ }^{182}$ The Clayton F. Summy Company admitted that it had collected more than $\$ 5000$ in such royalties, but disputed the Hill Foundation's claim to a share of them. ${ }^{183}$ Second, it sued the Postal Telegraph-Cable Company, alleging that that company had been using the song - with the "Happy Birthday to You" lyrics - as a singing telegram, without a license.

The complaints in those cases make, for the first time, assertions of authorship of the words of "Happy Birthday to You." They both contain a nearly identical paragraph which alleges that "one of the songs contained in [the books "Song Stories for the Kindergarten" and "Song Stories for the Sunday School"] is one entitled "GOOD MORNING TO ALL" which, with words written by the said Patty S. Hill, was later entitled "HAPPY BIRTHDAY TO YOU."184 That paragraph is followed in both complaints by another nearly identical paragraph which makes reference to "the said song, "HAPPY BIRTHDAY TO YOU," written and composed by the said PATTY S. HILL and MILDRED J. HILL.” Of course, as mere allegations in a complaint, these claims are not proper evidence of authorship, and the fact that they are first made approximately fifty years after the GMTA/HBTY combination was likely composed, when memories might be particularly susceptible to nudges from self-interest, makes them even weaker.

It is worth mentioning that these complaints do not clearly distinguish between different layers of copyright in succeeding derivative works, and do not assert that the GMTA/HBTY combination first secured federal copyright through publication with notice in 1935. Rather, the complaint against the Clayton F. Summy Company contains a most curious paragraph, which claims "[t]hat said work entitled 'GOOD MORNING TO

\footnotetext{
182 See Amended Complaint, pp. 6-7.

${ }^{183}$ See Answer to Amended Complaint, p 6.

${ }^{184}$ Amended Complaint in Hill Foundation v. Summy, p.3; Bill of Complaint in Hill Foundation v. Postal Telegraph-Cable Company, p. 2.
} 
ALL' (which included the said song known as 'HAPPY BIRTHDAY TO YOU') was duly copyrighted in the name of the aforesaid CLAYTON F. SUMMY under number C142,468 , on the $7^{\text {th }}$ day of February, $1907 \ldots .$. "185 In what way did the version of "Good Morning to All" that was published in 1907 "include" the song "Happy Birthday to You"? If it actually contained the HBTY lyrics as an additional verse, this article could be a great deal shorter. There would be much better evidence of the Hills' authorship of the GMTA/HBTY combination, and if that authorship were established, there would have been an authorized publication of the GMTA/HBTY combination in 1907. After proper renewal in 1935 and various legislative extensions of the renewal term, copyright would have expired in 1982. However, the copy of the 1907 publication that was deposited at the Copyright Office at the time of registration is no longer in the collection of the Library of Congress, and I have been unable to locate a copy. My guess is that the 1907 version did not actually include the "Happy Birthday to You" lyrics, and that the complaint was using the word "include" quite awkwardly to suggest some close connection, without a clear conception of the relation between a derivative work and preexisting material.

Quite naturally, the Clayton F. Summy Company's answer in that litigation denied that "Good Morning to All” could be described as "including” the song "Happy Birthday to You." "186 The Postal Telegraph-Cable Company similarly protested "that the words of the song 'Happy Birthday to You' are entirely different from the words of the song 'Good Morning to All.',187

vi. Popular Accounts of Authorship. There is no lack of popular accounts of the writing of "Happy Birthday to You," but they conflict, and none of them seems to have a superior claim to be authoritative. For example, Virginia Grattan writes in "American Women Songwriters: A Biographical Dictionary": "The [kindergarten] children liked the song [Good Morning to All] so much that they sang it at a birthday party, changing the words to 'happy birthday.",188 The source she cites is a book called "Living Stories of Favorite Songs," which recounts a conversation between Patty Smith Hill and an unnamed kindergarten student who recounts: "The children who came to my party sang a happy birthday song to me. .. . I wrote it for them. I just took your song 'Good morning to you' and changed it to 'Happy Birthday to you' and had the children sing it for me at my party." "189 But this conversation is clearly fictional, and in the book's preface the author writes: "I trust those authors and composers who are still alive . . . will excuse the liberties I took in writing some of the details of several of these stories, in order to bring out salient facts that are somewhat related to the actual history of the song."190

\footnotetext{
185 Amended Complaint in Hill Foundation v. Summy, p.8.

${ }^{186}$ Answer in Hill Foundation v. Summy, p. 8.

${ }^{187}$ Answer to complaint in Hill Foundation v. Postal Telegraph-Cable Company p. 2

${ }^{188}$ Virginia L. Grattan, American Women Songwriters: A Biographical Dictionary 196 (1993). Kembrew McLeod uncritically cites Grattan in support of his assertion that the "Happy Birthday to You" lyrics were created by "a spontaneous form of lyrical parody or alteration that is commonly employed in the folk song creation process.” Kembrew McLeod, "Musical Production, Copyright and the Private Ownership of Culture,” in Justin Lewis and Toby Miller, eds., Critical Cultural Policy Studies: A Reader 240, 244 (2003)

${ }^{189}$ Ernest K. Emurian, Living Stories of Favorite Songs 36 (1958)

${ }^{190} I d$. (preface on unnumbered page).
} 
There is also a story with slightly more detail about how Patty Smith Hill came up with the GMTA/HBTY combination. An 18-space public parking lot in Louisville was dedicated to Mildred and Patty Smith in 2002, and the bronze dedication plaque installed in that lot states that "'local history' recounts that during a birthday party for a Lisette Hast in the Little Loomhouse on Kenwood Hill, Patty Hill suggested the words 'good morning to all' be changed to 'happy birthday to you.",191 There does not seem to be any contemporary documentation of this story, however.

Sally Moss, the current Executive Director of the Little Loomhouse Foundation, believes that she heard the story from Louise Tate Bousman (professionally known as "Lou Tate"), who established the set of three cabins known as "the Little Loomhouse" as a weaving center. ${ }^{192}$ But Lou Tate could not have personally witnessed the birthday party. She was not even born until 1906 -- after Patty Hill had moved to New York and only a year before Etta Hast, Lisette Hast's sister, sold Esta Cabin, the particular cabin in question -- and her family did not move into the Louisville area until $1920 .{ }^{193}$ In fact, Lou Tate is likely to have first heard such a story much later, sometime after her mother purchased Esta Cabin in 1939. ${ }^{194}$ No one seems to know who actually witnessed the birthday party and how the story was passed down, which makes it seem a bit more like legend than a reliable factual account.

In addition, it seems clear that the birthday party in question could not have taken place before 1898, when Etta Hast, Lisette’s sister, purchased the Esta Cabin. ${ }^{195}$ That would mean that the birthday lyrics would have first been written five years after "Good Morning to All" was first published, and eight or nine years after it was written. Although this is not inconceivable, it seems to be in tension with Patty Hill's deposition statement that the birthday lyrics were used "with every birthday celebration in the school,"196 since it would mean that "Happy Birthday to You” could have been used in the Louisville kindergartens during, at most, the last seven years of Patty Hill's sixteenyear association with them. It seems far more likely that the birthday lyrics had already been in use in the kindergartens for some time, and that if a birthday party for Lisette Hast did feature a performance of "Happy Birthday to You" at the suggestion of Patty Hill, that was just one of the first performances in an adult setting.

\footnotetext{
191 Bob Hill, "Happily, you can still park here for a song,” Louisville Courier-Journal, Thursday, May 12, 2005. See also "The Happy Birthday Song and the Little Loomhouse," http://www.littleloomhouse.org/happybirthday.htm.

192 Conversation with Ms. Sally Moss, October 9, 2007.

193 See Alice S. Davidson, The Little Loomhouse: A Brief History 2 (1997) (Lou Tate Bousman was born on October 19, 1906; her family moved to Louisville in 1920); id. at 8 (Etta Hast purchased the cabin in 1898 and sold it in 1907).

${ }^{194}$ Id. at 8 (Lou Tate's mother purchased the cabin in 1939).

${ }^{195} \mathrm{Id}$.

196 [HVH 12] Deposition De Bene Esse 7-8 in Hill v. Harris, No. E 78-350, United States District Court for the Southern District of New York (Examination of Miss Patty S. Hill by Mr. Malcolm B. Stark).
} 
vii. A summary. So what does all of this evidence amount to? No court rulings ever; deposition testimony from Patty Smith and Jessica Hill that does not claim authorship of the GMTA/HBTY combination; registration applications that claim only arrangements; published versions that for many years credit only Mildred J. Hill, without specifying that she wrote the words; unsubstantiated claims in two complaints in the 1940s that Patty Smith Hill wrote the words; and conflicting popular accounts that may be fanciful, some by their own admission. Maybe more evidence would surface if the issue was ever litigated, but it is hard to say that the scraps that I have found would provide convincing proof of who combined the "Good Morning to All" melody with the "Happy Birthday to You” lyrics.

What a jury would do, and whether a judge would find that no reasonable jury could find on this evidence that Mildred or Patty Smith Hill created the GMTA/HBTY combination, are open questions. It seems clear that Summy-Birchard does not deserve any sympathy for the difficulty it would face in presenting evidence of authorship more than a century after the combination was likely created. It or its predecessors could have sought administrative and judicial determinations of authorship long, long ago, when Patty Smith Hill and other important witnesses were still alive. It has chosen to avoid all such opportunities, perhaps in part to avoid other legal difficulties. ${ }^{197}$ The legal result of a failure to prove authorship of the combination by Mildred or Patty Smith Hill is also clear. Without such a finding, there was no authorized publication in 1935 to obtain federal copyright, and Warner/Chappell, which traces its rights back to that 1935 publication, does not own any interest in the combination. ${ }^{198}$

To consider further issues about copyright in the GMTA/HBTY combination, then, we have to assume that a judge or jury would find that one or both of the Hill sisters wrote that combination. For the remainder of this Part of the article, I will generally assume that Mildred and Patty Smith Hill were joint authors of the GMTA/HBTY combination. Patty Smith Hill's deposition testimony suggests that the GMTA/HBTY combination was being used at a time when the sisters were working in very close collaboration on all of the songs published in "Song Stories for the Kindergarten"; they undoubtedly intended that the music, credited to Mildred, and the words, credited to Patty, would be joined together as a single work. It seems almost certain that any factfinder who decided that Mildred or Patty was responsible for the combination would also find that the combination was part of a collaborative process that involved both sisters. Thus, I will generally assume joint authorship.

2. Publication with Notice. Let us suppose that a factfinder - whether judge or jury - found that, by a preponderance of the evidence, Mildred and Patty Smith Hill did jointly author the GMTA/HBTY combination. In that case, we have an authorized

\footnotetext{
${ }^{197}$ See infra p. xx (arguing that at least before 1970, courts might have held that the GMTA/HBTY combination was injected into the public domain due to improper copyright notice).

${ }^{198}$ Of course, if someone else came out of the woodwork with a well-supported claim to be the author of the GMTA/HBTY combination, and that person had transferred his or her rights to the Clayton F. Summy Company or one of its successors, Warner/Chappell would be back in business. But there has never been any suggestion that such a person exists, and the chance of him or her appearing now, over a century after the fact, is vanishingly slim.
} 
publication of the combination in 1935, since Jessica Hill was a co-owner of that combination. Recall that under the 1909 Act, an authorized publication of a work with proper copyright notice was the route to federal copyright protection; conversely, an authorized publication without proper copyright notice forfeited all protection, and dedicated the work to the public domain. The two versions of the GMTA/HBTY combination published in 1935 bore the copyright notice "Copyright 1935 by Clayton F. Summy Co.” ${ }^{\text {,99 }}$ Was that proper notice?

Proper copyright notice generally had to include the name of an owner of copyright. When the 1909 Act said "owner" (or "proprietor") it really meant owner: a licensee, who had only limited rights of use under a contractual arrangement, even exclusive rights, wouldn't qualify. Three decades after the 1909 Act's demise, it is becoming difficult to imagine and sympathize with the potency of that distinction. But potent it was. $^{200}$ For example, in Egner v. Schirmer Music Co., ${ }^{201}$ Edwin Gruber, composer of the song "The Caissons Go Rolling Along," authorized Messrs. Egner and Mayer to include that song, previously unpublished, in an anthology titled "Songs of the United States Military Academy." Egner and Mayer published the anthology with a copyright notice under their names. The district court found that Gruber had not assigned copyright in the song to Egner and Mayer, but had merely licensed it, and that under those circumstances, publication with notice under Egner's and Mayer's names forfeited copyright in the song. The First Circuit affirmed.

Even while the 1909 Act was in force, courts recognized the difficulty of strictly applying the notice rules in some circumstances, and developed exceptions. One of the exceptions concerned derivative works that incorporated older material in which federal copyright had already been secured. This exception would have applied to the use of the "Good Morning to All" melody in the 1935 publication of "Happy Birthday to You." Copyright in "Good Morning to All” had, of course, already been secured back in 1893 by registration before publication. It was republished in 1935 with new material - both the new "Happy Birthday to You" lyrics, and the Forman and Orem arrangements. Copyright notice in the name of the Clayton F. Summy Company was undeniably proper with respect to the arrangements, because the Summy Company owned them as works made for hire. Under the "previously copyrighted underlying work" exception, copyright notice in the name of the Summy Company would not invalidate copyright in "Good Morning to All," even if Summy did not own that copyright, but had merely licensed it. As the court in Nom Music, Inc v. Kaslin ${ }^{202}$ put it:

[If] the published version of [a song] is in part protected by two different copyrights, which could have two different owners and do have two different

\footnotetext{
${ }^{199}$ See [S1], [S2].

${ }^{200}$ The newspaper and magazine publishing industries were particularly deeply affected. If a periodical was published with only a single copyright notice containing the name of its publisher, copyright protection would be forfeited in any of the periodical's articles that the publisher had merely licensed from their authors. That placed pressure on freelance authors to assign outright the copyright in their articles, a very sore spot for authors that eventually led to special protections in the 1976 Act.

${ }^{201} 48$ F. Supp. 187 (D. Mass. 1942), aff'd, 139 F.2d 398 (1 $1^{\text {st }}$ Cir. 1943).

202343 F.2d 198 (2d Cir. 1965).
} 
expiration dates, it might appear that the copyright notice should give the date and proprietor of each. But such has not been the interpretation adopted by this and other courts. . . . [I]t has been held that the notice need give only the date and owner of the copyright in the derivative work, leaving the reader to his own ${ }^{203}$ devices in ferreting out this information as to the original. ${ }^{204}$

In the Hill Foundation, Inc. v. Clayton F. Summy Co. litigation, the parties disputed whether Jessica Hill had assigned copyright in "Good Morning to All" to the Summy Company, or had merely licensed the song to it for limited purposes in connection with the publication of "Happy Birthday to You." That disputed issue could have had an impact on the distribution of royalties at issue in that litigation - royalties from dramatic and motion picture use of the song - but under the Nom Music rule, it would not affect the validity of copyright in "Good Morning to All." Even if Jessica Hill had merely licensed "Good Morning to All” to the Clayton F. Summy Company, copyright notice on the Forman and Orem arrangements in the name of the Company would have been proper.

But what about the GMTA/HBTY combination? Unlike "Good Morning to All," it had not been published with authorization of the copyright owner before the Forman and Orem arrangements were published in 1935 - at least that is the assertion of fact on which Summy-Birchard rests its claim that the combination is under federal copyright until 2030. It turns out that that fact matters: The Nom Music rule does not protect matter in which copyright was not previously obtained. The statutory basis for Nom Music is section 7 of the 1909 Act (originally enacted as section 6, but renumbered in a later codification). Section 7 provides, in relevant part:

That compilations . . . adaptations, arrangements . . . or other versions of copyrighted works when produced with the consent of the proprietor of copyright in such work, or works republished with new matter, shall be regarded as new works subject to copyright under the provisions of this Act; but the publication of any such new works shall not affect the force or validity of any subsisting copyright upon the matter employed or any part thereof $\ldots .{ }^{205}$

The last clause in that excerpt is the crucial one: it preserves "any subsisting copyright" in the face of publication of derivative works or compilations. "Any subsisting copyright" clearly encompasses matter in which federal copyright has been secured, but does it also encompass matter protected by state common-law copyright, as the GMTA/HBTY combination would have been? More recent cases have confirmed that it does not. $^{206}$

\footnotetext{
203 See supra n. 134.

${ }^{204} \mathrm{Id}$. at 200.

205 Act of March 4, 1909, 35 Stat. 1075, Chap. 320, §6.

206 In a number of cases in the 1990's, movie studios argued that even if a movie was in the public domain because the studio had failed to renew copyright in it, others could still not copy the movie, because the copies would infringe copyright in the script upon which the movie was based. The script had never been published and therefore was protected by state common-law copyright; section 7 of the 1909 Act, argued the studios, preserved that common-law copyright when the movie itself, a derivative work, was published.
} 
Thus, at least before a change in judicial attitude in 1970 - about which more below - it mattered a great deal whether Jessica Hill assigned copyright in the GMTA/HBTY combination to the Summy Company, or merely licensed it. It is possible, though unlikely, that Summy-Birchard has a written assignment of copyright in the unpublished GMTA/HBTY combination, dating from 1934 or 1935, squirreled away in its vaults. Absent such a document, however, the case for such an assignment seems weak. $^{207}$ It seems clear that the agreement under which the Summy Company used “Good Morning to All” was a license rather than an assignment. Under the 1909 Act, only the proprietor of copyright had standing to file a lawsuit to enforce it. ${ }^{208}$ Jessica Hill, not the Summy Company, was the nominal plaintiff in the lawsuits that were filed in 1934 for infringement of copyright in "Good Morning to All” - a reasonably certain indication that Jessica Hill remained the copyright proprietor, since if she had assigned copyright to the Summy Company, it would have brought the suits in its own name. Those lawsuits were still active in mid-1937, long after the 1935 publication of the Forman and Orem arrangements of "Happy Birthday to You." As of 1935, none of the parties seems to have had a clear conception of the GMTA/HBTY combination as a separate work that had its own copyright life independent of "Good Morning to All."209 At that time, "Good Morning to All” was still under copyright, with half its renewal term left to run; there was money to be made from publishing a version of it with some other

In Batjac Productions, Inc. v. GoodTimes Home Video Corp., 160 F.3d 1223 (9 ${ }^{\text {th }}$ Cir. 1998). however, the Ninth Circuit disagreed. Adopting a position advanced both by the defendant and the Copyright Office as intervenor, the Ninth Circuit held that section 7's protection of "any subsisting copyright" encompassed only federal statutory copyright, not state common-law copyright. See id. at 1228-33. The following year, the Second Circuit came to the same conclusion. See Shoptalk, Ltd. v. Concorde-New Horizons Corp., 168 F.3d 586, 592 (2d Cir. 1999).

${ }^{207}$ Common-law copyright in unpublished works, unlike federal copyright, could be transferred orally, or even by implication. See, e.g., Urantia Foundation v. Maaherra, 114 F.3d 955, 960 (9 $9^{\text {th }}$ Cir. 1977). I have not found evidence of any transfer, however, and to imply a transfer solely from the consequences of lacking one - to argue that Jessica Hill must have transferred copyright in the GMTA/HBTY combination because she surely did not want to forfeit copyright protection - seems to be an awfully charitable presumption. Some courts have been willing to imply a requirement of proper notice in a licensing agreement, so that any publication with improper notice would be unauthorized by the licensor, and hence would not forfeit copyright. See Fantastic Fakes, Inc. v. Pickwick International, Inc., 661 F.2d 479, 485-86 ( ${ }^{\text {th }}$ Cir. 1981); Judscott Handprints, Ltd. v. Washington Wall Paper Company, 377 F. Supp. 1372, 1379 (E.D.N.Y 1974). That would mean, however, that copyright on the GMTA/HBTY combination was not obtained in 1935, but only after the Clayton F. Summy actually obtained an ownership interest in the combination - probably 1944. See infra p. _. Since no renewal application was filed in the $28^{\text {th }}$ year after 1944, the Summy Company would have a very hard time claiming that under those circumstances "Happy Birthday to You" still remains under copyright.

${ }^{208}$ See, e.g., New Fiction Pub. Co. v. Star Co., 220 F. 994 (S.D.N.Y.1915); Goldwyn Pictures Corp. v. Howell Sales Co., 282 F. 9 (2d Cir. 1922).

${ }^{209}$ In its answers in Hill Foundation v. Clayton F. Summy Co., Summy asserts that Jessica Hill transferred "various piano arrangements to the said musical composition 'Good Morning to All' and all world rights . . . of and to copyright ... of said work." [HFVS 2], p.7; [HFVS 4], p. 7. Note that it does not mention any copyright "layer" in between the song "Good Morning to All" and the "piano arrangements," though it is crucial to Summy/Birchard's current copyright claims that the GMTA/HBTY combination be independent of both "Good Morning to All” and the "piano arrangements." 
words which had been around for a long time; and that was all anyone was thinking of. ${ }^{210}$ Thus, Jessica Hill did not assign copyright in the GMTA/HBTY combination to the Summy Company, but only impliedly licensed it. Under precedent like Egner $v$. Schrimer Music Co., publication of the merely licensed combination with notice that it was owned by the Clayton F. Summy Company would have forfeited copyright in it.

In 1970, the Second Circuit held in Goodis v. United Artists Television, Inc., ${ }^{211}$ that copyright notice in the name of a mere licensee - the publisher of a magazine would not forfeit copyright protection in a novel that was serialized in that magazine. Both judicial and legislative attitude was turning away from strict notice requirements and the so-called "indivisibility doctrine," under which holders of licenses, even exclusive licenses, that covered less than all of the rights subsumed under copyright could not claim to be owners. Drafts of the 1976 Act, which would greatly soften notice requirements and put exclusive licensees on a par with owners, had been circulating for quite some time, and Goodis cited those drafts heavily. ${ }^{212}$ In the 1981 case of Fantastic Fakes v. Pickwick International, ${ }^{213}$ the Fifth Circuit followed the Second, also holding that copyright notice in the name of a licensee would not forfeit copyright, at least when no one had been misled by that notice. ${ }^{214}$ The Ninth Circuit jumped on the bandwagon in 1988, in Abend v. MCA. ${ }^{215}$

After Goodis, Fantastic Fakes, and Abend v. MCA, it is much less likely that the Summy Company's probable status as a mere licensee of the GMTA/HBTY combination would mean that its publication of that combination with copyright notice under its own name would have forfeited copyright in it. Thus, we have the curious situation that copyright in the GMTA/HBTY combination might well have been lost had the issue been litigated anytime during its original term, between December 6, 1935 and December 5, 1963. Now, however, notice problems are much less likely to be grounds for holding that the GMTA/HBTY combination is not under copyright.

C. The Renewal Term. December 5, 1963 came and went a long time ago. The GMTA/HBTY combination could only still be under copyright if a renewal application was properly filed in that last year of the original term. Was it? Surprisingly, no one filed a renewal application that on its face covers the GMTA/HBTY combination. The Summy-Birchard Company, successor to the Clayton F. Summy Company, filed the only renewal applications on record at the Copyright Office. It filed six applications in 1962,

\footnotetext{
${ }^{210}$ As late as 1948, Samuel Mann, attorney for Patty and Jessica Hill, apparently told a reporter that "[t]he master copyright will expire next year, but several rights on arrangements will last another 20 years," indicating that even then an attorney who had good reason to be familiar with the copyright status of "Happy Birthday to You" did not think that there was a separate copyright in the GMTA/HBTY combination that would survive after 1949. Rhea Talley, "Their Song Becomes a Universal One," Louisville Courier-Journal, February 15, 1948, Section 2, page 8 ("Information about the song came from the Hills’attorney, Samuel Mann”).

${ }^{211} 425$ F.2d 397 (2d Cir. 1970).

${ }^{212}$ Id. at $402-03$.

${ }^{213} 661$ F.2d 479 (5 ${ }^{\text {th }}$ Cir. 1981).

${ }^{214}$ See id. at 486-87.

${ }^{215} 863$ F.2d 1465, 1469-70 ( $9^{\text {th }}$ Cir. 1988).
} 
corresponding to the six registrations it had procured in 1934 and 1935. On December 6, 1962, the first possible day that it could have done so, it filed renewal applications for the Forman and Orem arrangements containing the GMTA/HBTY combination. Those applications, however, specifically confine themselves to the musical arrangements. Question 3 on the renewal applications asks the applicant to state the "Authors of renewable matter: Give the names of all authors who contributed copyrightable matter to this version but not the names of authors of previous versions." The Summy-Birchard Company answered, respectively, "Clayton F. Summy Company (now by change of name, Summy-Birchard Company) as employer for hire of Mrs. R.R. Forman,"216 and "Clayton F. Summy Company (now by change of name, Summy-Birchard Company) as employer for hire of Preston Ware Orem." ${ }^{217}$ Assuming, as I think we can, that neither Mrs. R.R. Forman nor Preston Ware Orem was responsible for the GMTA/HBTY combination, ${ }^{218}$ the renewal application was not directed at that combination. Was it nonetheless effective to obtain a renewal term in the combination? That question is best addressed in two parts: first, was the Summy-Birchard Company qualified to file a renewal application for the GMTA/HBTY combination, and second, would its application be effective to obtain a renewal term in the combination?

1. Summy-Birchard's Eligibility to Apply for Renewal. We have already had occasion to touch on the renewal provisions of the 1909 Act in connection with the 1921 renewal of "Song Stories for the Kindergarten." Recall that the 1909 Act generally grants renewal rights, first, to the author. ${ }^{219}$ If the author has died before the last year of the original term begins, then the Act grants the renewal rights to the author's "widow, widower, or children"; if there are no surviving members of that class, then to the author's executor; and if the author left no will, then to the author's "next of kin.”

The 1909 Act has one further wrinkle, however, which comes to the aid of the Summy/Birchard Company. The Act provided that the renewal rights in "posthumous works" that first gained federal copyright protection after the effective date of the Act (July 1, 1909) were owned, not by the author, but by the "proprietor of copyright," that is, by whoever owned copyright in the original term of copyright in the work during its last year, when the renewal application had to be filed. ${ }^{220}$ "Posthumous works" were those that were published after the death of the author. Because Mildred Hill died in 1916, nineteen years before any authorized publication of the GMTA/HBTY combination, the

\footnotetext{
${ }^{216}$ [R 18].

${ }^{217}$ [R 21].

${ }^{218}$ See supra p. $\mathrm{xx}$.

${ }^{219}$ The GMTA/HBTY combination, if first published in 1935, would be subject to §23 of the 1909 Act, whereas "Song Stories for the Kindergarten," in which copyright was secured before the 1909 Act, was governed by §24. This doesn’t make a difference to the treatment of Patty Smith Hill’s interest, but as we will see below, it does make a difference to the treatment of Mildred Hill's interest.

${ }^{220}$ Act of March 4, 1909, 35 Stat. 1075, Chap. 320, § 24 (“'II]n the case of any posthumous work ... the proprietor of such copyright shall be entitled to a renewal and extension of the copyright in such work ... .”). The category of posthumous works has been narrowly construed to exclude any copyright assignment or other contract for exploitation of the work occurred during the author's lifetime. See Bartokv. Boosey \& Hawkes, Inc., 523 F.2d 941 (2d Cir. 1975). Clearly, however, there was no assignment or other contract for exploitation of "Happy Birthday to You" during Mildred Hill's lifetime, however, so with respect to her the GMTA/HBTY combination is still a posthumous work.
} 
combination would qualify in relation to her as a posthumous work. Thus, if the SummyBirchard Company had gained ownership of some portion of Mildred Hill's interest in the combination by 1962, it would be eligible to file a renewal application in that combination.

Once again, for the complete details of transfers of ownership in interests in "Good Morning to All” and in the GMTA/HBTY combination, I will refer the reader to the online appendix that traces ownership. ${ }^{221}$ The short answer is that the Clayton F. Summy Company did gain ownership of at least a portion of Mildred Hill's interest in the GMTA/HBTY combination. In 1944, as part of the settlement of Hill Foundation, Inc. v. Clayton F. Summy Co., Patty and Jessica Hill executed a very thorough set of conveyances to the Hill Foundation, ${ }^{222}$ which in turn conveyed those interests to the Summy Company. ${ }^{223}$ The conveyances encompassed all of the sisters' interests in all six of the versions of "Happy Birthday" and "Happy Birthday to You” registered in 1934 and 1935; in any renewals and extensions thereof; and in any further arrangements that might be made of those works in the future. ${ }^{224}$ Since all of Jessica's interest and part of Patty's interest were inherited from Mildred, either directly or through her sister Mary, the Summy Company thereby became a proprietor of copyright in the posthumously published GMTA/HBTY combination, and would have been entitled to file an application to renew that copyright.

An extraordinary term of the settlement in Hill Foundation v. Clayton F. Summy Co., and an extraordinary episode that likely explains that term, is worth a substantial digression. There is good authority that in exchange for the Hill Foundation's interests in "Good Morning to All” and "Happy Birthday to You," the Summy Company agreed to pay the Hill Foundation one-third of all royalties generated by "Good Morning to All" and "Happy Birthday to You."225 The strong custom of the time was to split royalties evenly between the music publisher and the authors, ${ }^{226}$ and indeed, the agreement between Jessica Hill and the Summy Company under which the 1934 and 1935 versions of "Happy Birthday to You" were originally published provided for such an even split. ${ }^{227}$ Why did the Hill Foundation agree to accept a substantially smaller share of royalties? Patty and Jessica had already gained control of their nephew Archibald Anderson's interest in "Good Morning to All" through a 1939 conveyance. ${ }^{228}$ But in that same year, a dubious gambit of the Summy Company resulted in it gaining a colorable claim to the

\footnotetext{
${ }^{221}$ See [A1].

${ }^{222}$ See [RA5].

223 See [RA6].

${ }^{224}$ See [RA5], [RA6].

225 [JMH 14], pp. 3-4.

${ }^{226}$ See, e.g., Biederman et al, Law and Business of the Entertainment Industries 642 (5 $5^{\text {th }}$ ed. 2007) ("For many years music publishing revenues have essentially been divided equally between the writer and publisher, a practice followed through most of the world. Thus, in theory, 50 cents of every dollar collected by the publisher will be paid to the songwriter and 50 cents will be retained by the publisher in most deals.”).

${ }^{227}$ See [HFVS 3], p. 8 (paragraph 26 of the Hill Foundation's amended complaint); [HFVS 4], p. 8 (the Summy Company's amended answer, admitting the 50/50 royalties split).

${ }^{228}$ See [RA1].
} 
one-eighth interest inherited from Mildred and Mary by their brother William Wallace, for the shockingly low sum of twenty-five dollars.

The Summy Company's gambit involved having William Wallace Hill's estate reopened, and persuading the probate court to hold a private sale of William Wallace's interest in "Good Morning to All." William Wallace had named his wife Corinne Dorothy Hill as executrix of his estate, but she had died in 1934. In 1939, the attorney who had represented Corinne Dorothy Hill as executrix, Leo B. Lowenthal, petitioned the Probate Court of Cook County, Illinois to withdraw from that representation, and to have the court appoint one Allen Davy as an "Administrator de bonis non with will annexed" of William Wallace Hill's estate, replacing the deceased executrix. The court granted those petitions, and Allen Davy, presumably bankrolled by the Clayton F. Summy Company, ${ }^{229}$ took an oath that as Administrator he would "make . . . a true and perfect inventory" of all of William Wallace Hill's property of which he knew, and would "pay and delver to the persons entitled thereto, all the legacies and bequests contained in said will ... according to the value thereof . . . .,230

Allen Davy proceeded to approve an inventory that valued William Wallace Hill's one-eighth interest in "Good Morning to All” at \$15, and then, when there was some doubt whether William Wallace Hill might not have a one-quarter interest, valued the one-quarter interest at $\$ 15$ as well. ${ }^{231}$ In 1939 , of course, the melody of "Good Morning to All” had featured in over 400 performances of a musical on Broadway; in a series of radio broadcasts; and in several motion pictures. Jessica Hill and the Clayton F. Summy Company had thought the song was valuable enough to pay the cost of bringing two infringement lawsuits in federal court, and taking them all the way to trial. Three years later, in 1942, the Clayton F. Summy Company admitted that it had by then collected over $\$ 5000$ in licensing fees for the song, not counting revenues from the sale of sheet music. Fifteen dollars was an absurdly low estimate of the value of William Wallace Hill's interest.

\footnotetext{
${ }^{229}$ Mr. Lowenthal told the court that he was "informed that there are certain parties willing to purchase [William Wallace Hill's copyright interests] and to bear such further expense and to bear such further expense as may be involved in completing the administration of the estate of WILLIAM WALLACE HILL.” [WWH 1], http://docs.law.gwu.edu/facweb/rbrauneis/happybirthday/wwhill/Petition_For_Letters_Of_Administration. pdf.

${ }^{230}$ [WWH 2], p.3.

${ }^{231}$ Why did the lawyers working on this transaction think that William Wallace Hill might have a onequarter interest in the renewal term of "Good Morning to All”? He owned one-quarter of Mildred Hill's interest in that song, but she herself only owned a one-half interest in the song, since it was a joint work coauthored by her sister Patty. Perhaps there was some thought that Jessica's 1921 renewal application was not sufficient to renew Patty's interest; but in retrospect, at least, it seems clear that the Second Circuit has decided as early as 1921 that a renewal by one co-owner of copyright was sufficient to secure the renewal term interests of all of the other co-owners. See Silverman v. Sunrise Pictures Corp., 273 F. 909 (2d Cir. 1921), cert. denied, 262 U.S. 758 (1923). Of course, there was no disadvantage to getting court approval of a sale of William Wallace Hill's interest as a one-quarter interest; if it turned out to be merely a one-eighth interest, the heirs of Corinne Dorothy Hill certainly couldn’t complain.
} 
Allen Davy then petitioned the probate court to hold a private sale of the interest, representing to the court that a public sale would generate no more revenue than a private one. The court approved the petition, and, on March 22, 1939, Davy sold William Wallace Hill's interest in "Good Morning to All” to the Clayton F. Summy Company for $\$ 25$ - a generous ten dollars over the inventory value of that interest. ${ }^{232}$ To make matters worse, Louise Altenhofen and Sophia A. Smith, Corinne Dorothy Hill's heirs, did not get one penny of that \$25. It all went to Leo Lowenthal, Corinne Dorothy Hill's attorney, who represented to the court that he had unpaid legal bills for services provided to her in excess of that amount. Presumably, the Clayton F. Summy Company paid Allen Davy well for his services, and may well have also paid Leo Lowenthal something. All Altenhofen and Smith got was a mailed copy of the cryptic, brief notice of the hearing at which Allen Davy would present his report as administrator and ask to be discharged; that notice, of course, did not identify the property that had been sold. ${ }^{233}$

The Summy Company's claim to that one-eighth interest, along with a dispute over some earlier conveyances that Patty and Jessica Hill had executed, probably explains why it was able to gain their interests (and the interest they had acquired from their nephew Archibald Anderson) for a mere one-third of royalties received, a reduced cut that has by now left the Summy Company and its successors millions of dollars richer. Interestingly enough, however, neither Allen Davy's conveyance from William Wallace Hill's estate to the Summy Company, ${ }^{234}$ nor Archibald Anderson's conveyance to Patty and Jessica Hill, ${ }^{235}$ seems to have included any interest in the GMTA/HBTY combination; they both appear to have been limited to "Good Morning to All." Whether the legatees or heirs of Louise Altenhofen and Sophia Smith, or the residual legatee of Archibald Anderson Hill, still have some claim to own part of what would amount to one-quarter of the copyright in the GMTA/HBTY copyright, a copyright generating close to $\$ 2$ million a year, is a question that I will leave to other enterprising lawyers.

\section{The Sufficiency of the Renewal Applications.}

Recall that the six original registration applications filed by the Clayton F. Summy Company in 1934 and 1935 were limited to the arrangements prepared as worksmade-for-hire by Preston Ware Orem and Mrs. R. R. Forman. That would not have precluded the GMTA/HBTY combination from gaining federal copyright protection,

\footnotetext{
232 [WWH 26], p.1

233 See [WWH 32]

234 The interests that the Summy Company bought for \$25 in the private sale were interests in copyrights identified by a list of four registrations and their respective renewals - two in "Song Stories for the Kindergarten," representing the 1893 and 1896 published versions of that book; one in "Song Stories for the Sunday School," published in 1899; and one in the 1907 publication of "Good Morning to All." See [RA2], p. 2. Summy-Birchard's claim that the GMTA/HBTY combination is still under copyright rests on the argument that it is a completely separate derivative work that was first published in 1935 . The assignment from Allen Davy to the Clayton F. Summy Company makes no mention of any unpublished works, nor of the 1934 and 1935 registrations, but confines itself to the earlier registrations. Id. Thus, it did not transfer any interest in the GMTA/HBTY combination to the Clayton F. Summy Company.

${ }^{235}$ The conveyance from Archibald Anderson to Patty and Jessica contains the same list of four registrations and their respective renewals as the assignment from Davey to the Clayton F. Summy did, and it does not mention rights in unpublished works or in the 1934 and 1935 registrations. See [RA1].
} 
because under the 1909 Act the original term of copyright is obtained by publication with proper notice, not by registration. To obtain protection for the renewal term, however, registration was necessary. Under Copyright Office procedures, a work had to be registered for its original term before a renewal term application could be processed; but if the work sought to be renewed had not been previously registered, applicants could submit the original and renewal term applications at the same time, along with the deposit copies of the work. ${ }^{236}$ With respect to the GMTA/HBTY combination, Summy-Birchard could have submitted both an original registration and a renewal application between December 1962 and December 1963. It did not do so, however, and neither did anyone else. $^{237}$

Rather, Summy-Birchard filed six renewal applications that precisely mirrored their original registrations. In particular, with respect to the two versions of "Happy Birthday to You" that contained the GMTA/HBTY combination, Summy-Birchard claimed a renewal term only in the arrangements created as works-for-hire by Preston Ware Orem and Mrs. R.R. Forman. ${ }^{238}$ Thus the issue becomes, could those renewal applications, explicitly limited to the arrangements alone, nonetheless be treated as sufficient to renew copyright in the GMTA/HBTY combination?

Copyright in the Forman and Orem arrangements is certainly a separate matter from copyright in the GMTA/HBTY combination, even though they were first published at the same time. There is no evidence that anyone ever thought that the arrangements and the GMTA/HBTY combination were supposed to be treated together as "joint works," which would make the Clayton F. Summy Company a co-owner of copyright in the combination. Thus, it is perfectly possible for the arrangements to have been renewed, while the combination itself could have fallen into the public domain due to a failure to renew. Taking the renewal applications at face value, that is exactly what seems to have happened.

Two other possibilities for saving copyright arise, however: an administrative procedure for correcting errors, and a judicial tradition of excusing them. Section 408(d) of the current Copyright Act authorizes the Copyright Office to promulgate regulations establishing procedures "for the filing of an application for supplementary registration, to correct an error in a copyright registration or to amplify the information given in a registration." 239 The Copyright Office has promulgated such regulations, including a

\footnotetext{
236 See Compendium of Copyright Office Practices (As of July 1, 1970) §11.3.1, at p. 11-11.

${ }^{237}$ For an explanation of who else might have been able to file a renewal application, see [A1].

238 One of the renewal applications actually differed in one detail. The renewal application for the arrangement by Mrs. R. R. Forman explicitly identified the arrangement as a work made for hire, whereas the original term registration had not. It seems quite likely that the arrangement had in fact been a work made for hire, and the original term application had simply failed to mention that. I don't think that failure would actually affect the status of the arrangement as a work made for hire, if indeed it was. If it wasn't, then Summy/Birchard was not the proper party to renew it, and the arrangement would now be in the public domain. That would not likely affect the copyright status of the GMTA/HBTY combination, however, because the Preston Ware Orem arrangement of that combination, published on the same day, almost certainly was a work for hire, identified as such, in which Summy-Birchard owned the renewal rights.

23917 U.S.C. $\S 408(d)$.
} 
provision that specifically provides for correction of renewal regulations under certain circumstances. ${ }^{240}$ None of those circumstances are present here, however.

The current version of the regulation that provides for correction of renewal registrations has three sentences, each describing circumstances under which a supplementary registration is allowed. The first does not apply because it provides that "supplementary registration to correct the renewal claimant or basis of claim or to add a renewal claimant is ordinarily possible only if the application for supplementary registration and fee are received in the Copyright Office within the last year of the relevant first-term copyright." 241 There was no such supplementary application filed with respect to the Forman and Orem versions of "Happy Birthday to You" back in 1962 or 1963. The second sentence is limited to errors or omissions that are "extremely minor," and that " $\mathrm{d}[\mathrm{o}]$ not involve the identity of the renewal claimant or the legal basis of the claim." 242 An error that consists of claiming an arrangement of a song rather than the song itself can hardly be described as "extremely minor," since it is a matter of claiming rights in two different works of authorship. ${ }^{243}$ The third and last sentence concerns cases in which "clear, convincing, objective documentation is submitted to the Copyright Office which proves that an inadvertent error was made in failing to designate the correct living statutory renewal claimant in the basic renewal registration." ${ }^{244}$ That circumstance isn't present here either, because the error made was not a failure "to designate the correct living statutory renewal claimant"; it was a failure to properly designate the work in which renewal term copyright was being sought. Thus the administrative procedure for correcting errors in renewal registrations will not help Summy-Birchard.

Quite apart from the administrative correction procedure, however, courts have also been willing to excuse inadvertent errors in registration applications. To determine whether the kind of misstatements made in the renewal applications for the Forman and Orem arrangements would count as excusable error, it will be helpful to examine both the reported case that is factually most similar to these, and the general rule that is sometimes said to arise from the cases.

The frequently-cited case of Baron v. Leo Feist, Inc. ${ }^{245}$ is in many respects similar to that of "Happy Birthday to You." In Baron, the registration application for a group of 12 songs listed Maurice Baron in the space for "Name of composer," but the word "composer" had been stricken out, and the words "arranger/transcriber" had been written above it. In the space for "Author of words," the application stated "Creole lyrics

\footnotetext{
240 See 37 C.F.R. §201.5(b)(iv).

${ }^{241} I d$.

${ }^{242} I d$.

${ }^{243}$ Arguably, such an error also involves the legal basis of the renewal claim, since in the renewal applications as actually filed Summy-Birchard was claiming renewal rights as the author of a work made for hire, and in a supplementary registration it would be claiming renewal rights as the assignee of copyright in a posthumously published work. However, one court has stated an error in claiming as an author of a work for hire instead of as an assignee "probably" does not involve the legal basis of the renewal claim. See Urantia Foundation v. Maaherra, 114 F.3d 955, 962 (9 $9^{\text {th }}$ Cir. 1997).

24437 C.F.R. §201.5(b)(iv).

245173 F.2d 288 (2d Cir. 1949).
} 
collected by Massie Peterson (U.S.A.) and Lionel Belasco (Trinidad, B.W.I.) - English version by Olga Paul (U.S.A.)." The plaintiffs in Baron introduced credible evidence that Lionel Belasco had actually composed the melody of one of the songs, "L'Année Passée." The district court ruled that the plaintiffs could sue for infringement of the musical composition even though Belasco was not indicated to be the composer of the melody on the registration application, ${ }^{246}$ and the Second Circuit affirmed. ${ }^{247}$

The Second Circuit noted that the application was correctly filed on the form for "new music first published," not the form for "republished musical composition with new matter," thus giving notice that a claim of copyright was being made with respect to the entire song including the melody, not just an arrangement or translation. ${ }^{248}$ The court also noted that the printed copies of the songs deposited in the Copyright Office with the application "described the songs as Calypso Songs 'by Massie Patterson and Lionel Belasco," thus correctly claiming authorship. ${ }^{249}$ Thus, concluded the court, "no one who examined the record in the Copyright Office would be justified . . . in believing that the melodies had been dedicated to the public.",250

There are good reasons to distinguish the facts of the present case. The original registrations for "Happy Birthday to You" were not filed on the form for "new music first published," but on the form for "republished musical composition with new matter." The latter form, of course, was the correct one, because the melody of the Forman and Orem versions was that of the previously published song "Good Morning to All," and the Clayton F. Summy Company was not in any case claiming copyright in that melody. But if a claim is being filed only for a portion of a published work - only for one "layer" comprising new matter added to the old -- then it becomes important to identify precisely what that new matter is, so that the Copyright Office and the public can understand the scope of the claim, and identification of the author of new copyright matter is an important part of identifying the new matter itself. In both the original and renewal applications, the sole authors of new copyright matter were identified as Mrs. R.R. Forman and Preston Ware Orem. Unlike the applications at issue in Baron, these applications could mislead the public as to the scope of the applicant's claims, because it is clear that neither Forman nor Orem wrote the first verse of "Happy Birthday to You."

The court in Baron is also willing to look at the deposit copies as possible correctives to errors in the applications, but the deposit copies of "Happy Birthday to You" do not help. They do not explicitly credit the words to anyone, and even if they credited the words to Mildred or Patty Hill, that would seem to only make it clearer that Summy and Summy/Birchard were not claiming copyright in the GMTA/HBTY combination, but only in the material that Forman and Orem contributed, namely, musical arrangements and, in Forman's case, additional words that are obscure and unimportant.

\footnotetext{
${ }^{246}$ Baron v. Leo Feist, 78 F. Supp, 686 (S.D.N.Y. 1948).

${ }^{247}$ Baron v. Leo Feist, 173 F.2d 288 (2d Cir. 1949).

${ }^{248} I d$. at 290.

${ }^{249} \mathrm{Id}$.

${ }^{250} \mathrm{Id}$.
} 
Lastly, it is important to note that the Baron case involves an original term registration, whereas the issue here is whether the renewal term registrations properly include the GMTA/HBTY combination. Recall that under the 1909 Act scheme, registration is not necessary during the original 28-year term to obtain federal copyright protection; rather, it is only a procedural prerequisite to filing an infringement suit. ${ }^{251}$ Courts have often reasoned that the nature of registration as a mere procedural requirement should lead to more lenient treatment of errors in applications, since finding fault in a registration does not change the substantive rights of the parties, but just puts the plaintiff through the inconvenience of filing another registration application and another infringement suit. ${ }^{252}$ Yet renewal registrations are different. Under the 1909 Act, they are a condition of copyright protection, and whatever is not claimed in the renewal application will fall into the public domain at the end of the original term. Thus, unlike the original term application at issue in Baron, the renewal applications here are not mere technicalities, and claimed mistakes should not be excused on that ground.

Summy/Birchard would also undoubtedly lean heavily on a statement that some cases frame as a general rule, namely that an error in a registration application will not invalidate the registration unless the error is fraudulent, that is to say, unless the applicant knowingly misstated or failed to state "facts which might have occasioned a rejection of the application."253 There must be some limit to the scope of this rule, since it seems unlikely that a registration application that stated the title of a different work altogether could be considered an inadvertent error. For example, if Mary Hemingway wanted to renew copyright in Ernest Hemingway’s “The Green Hills of Africa,” serially published in Esquire magazine in 1935, ${ }^{254}$ but by mistake filed a renewal application for "He Who Gets Slap Happy," another Hemingway piece published by Esquire in 1935, ${ }^{255}$ would the error of entering the wrong title, registration number, and date on the renewal application be considered excusable if it could be proven that it was inadvertent? Or to move one step closer to the instant case, if a renewal application were filed for "The Green Hills of Africa," but inadvertently only for the illustrations by Edward Shenton ${ }^{256}$ rather than the text by Ernest Hemingway, thus listing the wrong author and the wrong type of work, would that be considered excusable? If not, then there is an argument that the 1962 "Happy Birthday to You" renewals, which designate an arrangement written by a different author than the underlying song, should not fall within the scope of the “inadvertent error” rule either.

\footnotetext{
251 See supra p. xx.

252 See, e.g., Axelrod \&Cherveny Architects, P.C. v. Winmar Homes, 2007 WL 708798 (E.D.N.Y. 2007) (noting “the longstanding principle that, since 'registration is not a condition of copyright protection,'see 17 U.S.C. § 408(a), courts should not treat the registration requirement as a technical trap, and inadvertent mistakes should only become an issue when they are detrimentally relied upon”).

${ }^{253}$ Russ Berrie \& Co. v. Jerry Elsner Co., 482 F.Supp. 980, 988 (S.D.N.Y. 1980); see, e.g., Lamps Plus, Inc. v. Seattle Lighting Fixture Co., 345 F.3d 1140, 1145 ( $9^{\text {th }}$ Cir. 2003); Nimmer on Copyright $\S 7.20[B]$.

${ }^{254}$ See U.S. Copyright Renewal Registrations R305991-R305997 (Dec. 5, 1962).

255 See U.S. Copyright Renewal Registration R305402 (Nov. 30, 1962).

${ }^{256}$ See U.S. Copyright Renewal Registration R305990 (Dec. 6, 1962). I am not suggesting that any of these renewal applications were filed in error, but just posing hypotheticals using them.
} 
If the inadvertent error rule did apply, that would of course greatly favor SummyBirchard, since it is always difficult to show that an error or omission was knowing. It is not difficult, however, to show that there are reasons why Summy-Birchard might have wanted to avoid having to formally register and renew the GMTA/HBTY combination.

The first reason concerns the authorship of the combination, and of "Good Morning to All” itself. By the renewal year of 1962-63, it would have been clear how important it was to establish that Patty Hill had co-authorship rights in the melody of "Good Morning to All," and also in the GMTA/HBTY combination, in order to extend the term of copyright protection for those works in many foreign countries.

Back in 1908, the countries that were parties to the Berne Convention decided that the minimum term of copyright protection should be the life of the author plus 50 years ${ }^{257}$ in 1928, they clarified that in the case of joint works, the term should extend through the life of the last surviving author plus fifty years. ${ }^{258}$ The United States did not become a party to the Berne Convention until March 1, 1989, but it had copyright relations dating back to the 1890s with many countries that were parties. Many of those countries extended "national treatment" to United States authors, offering them copyright protection on the same terms as their own citizens. The upshot is that, from the perspective of 1962-63, the renewal year for the GMTA/HBTY combination, both "Good Morning to All” and "Happy Birthday to You" would enjoy a life-of-the-author-plus-50years term in important markets like Germany and France. ${ }^{259}$

If Mildred Hill were considered the sole author of the "Good Morning to All" melody and the GMTA/HBTY combination, copyright protection under a Berneminimum law would end in 1966, fifty years after her death in 1916. As you will recall, however, Patty Hill outlived her sister by 30 years, so that protection for a jointly-

\footnotetext{
${ }^{257}$ See Act of Berlin of November 13, 1908, Article 7.

${ }^{258}$ See Act of Rome of June 2, 1928, Article 7bis.

${ }^{259}$ The international protection of works written by United States citizens and published in the United States before the advent of the Universal Copyright Convention in the late 1950s is an extremely complicated subject. An important fact to know would be whether "Happy Birthday to You" was simultaneously published in a country that was a party to the Berne Convention. See Nimmer on Copyright $\S 17.04[\mathrm{D}]\{2]$. I think it is quite unlikely that the song was simultaneously published in a Berne country, but I have been unable to rule it out. It seems clear, however, that even in the absence of simultaneous publication, protection would be available in some important countries. In Germany, protection would be based on a copyright treaty concluded between it and the United States in 1892. See Presidential Proclamation No. 24, 27 Stat. 1021 (April 15, 1892) (establishing copyright relations between the United States and Germany on the basis of a bilateral treaty providing for national treatment for authors who were United States citizens). In France, it would be available on the basis of French law, recognized in 1891 as offering national treatment to United States citizens. See Presidential Proclamation No. 3, 27 Stat. 981 (July 1, 1891) (establishing copyright relations between the United States and Great Britain, France, Belgium and Switzerland on the basis of assurances that those countries extended national treatment to authors who were United States citizens). For the term that was applicable in France and Germany in the early 1960s -- fifty years after the death of the last surviving author --see Loi sur le Droit d'Auteur Art. 21, in Lois et Traités sur le Droit d'Auteur, Tome II, p. 768 (1962) (France); . Loi sur le Droit d'Auteur: Oeuvres Littéraires et Musicales Arts. 29, 30, in Lois et Traités sur le Droit d’Auteur, Tome I, pp. 24-25 (1962) (Germany).
} 
authored “Good Morning to All” melody and GMTA/HBTY combination would last until 1996 under a Berne-minimum law. ${ }^{260}$

The problem is that the versions of "Happy Birthday to You" published with lyrics in the United States did not in 1935 or for many years later carry Patty Hill's name; they gave sole credit to Mildred. ${ }^{261}$ Thus, the Summy-Birchard Company would either have to register and renew the GMTA/HBTY combination under Mildred Hill's name as sole author, or it would have to explain why the copies it was depositing with its registration did not list one of the authors of the work. This would have no impact on U.S. copyright protection, but it could put Summy-Birchard in an uncomfortable position in many other countries if word about this dilemma ever got back to them.

Second, as noted above, the original registrations for the versions of "Happy Birthday to You" that contained the GMTA/HBTY combination were submitted on forms for "Republished Musical Composition(s) With New Copyright Matter," and the new copyright matter identified appears to consist only of the musical arrangements and an additional, unused verse. As astute copyright examiner might inquire as to whether the GMTA/HBTY combination was really first published in 1935, since the original registrations seem to suggest that it was being republished at that time. Summy-Birchard might well be able to come up with a convincing answer, but that answer would likely commit it to a much more definite version of events than the one currently posted on the Warner-Chappell website, namely, "[t]he birthday lyric was added later."262 There are obvious strategic advantages to remaining uncommitted and vague about how federal copyright in the GMTA/HBTY combination was obtained in 1935 and came into the hands of Summy-Birchard.

Third, Summy/Birchard did not have a copy of the Orem arrangement registered in 1935 as E pub 51990 back in 1935 to deposit with its registration of the GMTA/HBTY combination. A January 23, 1961 letter from William Lichtenwanger, then Acting Head of the Library of Congress Reference Section, to Robert G. Olson at Summy/Birchard, reveals that Summy/Birchard had over a period of fifteen years made repeated requests to the Library of Congress to search for the original deposit copy, but the Library never

260 Of course, subsequent developments have extended the term of copyright to life plus seventy years in both the United States and Europe. See Council Directive 93/98/EEC of 29 October 1993 harmonizing the term of protection of copyright and certain related rights; P.L. No. 105-298, 112 Stat. 2827 (Oct. 27, 1998). The song "Happy Birthday to You," i.e., the GMTA/HBTY combination, is still listed in the online repertoire databases of SACEM ("Société des Auteurs, Compositeurs et Éditeurs de Musique," the French musical performing rights society), see http://www.sacem.fr/catel/fwk/main.jsp, and GEMA ("Gesellschaft für musikalische Aufführungs- und mechanische Vervielfältigungsrechte," the German musical performing and mechanical rights society), see https://mgonline.gema.de/werke/initSearch.do?lan=en, suggesting that they consider it to be still under copyright in those countries. The International Standard Work Code for the composition is T-072.639.3323; its GEMA work number is 545061-002.

${ }^{261}$ See supra p. xxx.

${ }^{262} \mathrm{See}$

http://www.warnerchappell.com/wcm_2/song_search/song_detail/songview_2.jsp?menu_status=songsearc h\&esongId=126621000 
found it. ${ }^{263}$ Apparently, Summy/Birchard had not preserved a copy of that edition either. With no copy of that edition to deposit, Summy/Birchard would have found it difficult to register it, though it could still have registered the GMTA/HBTY combination as it appeared in the Forman arrangement originally registered as E pub 51989. ${ }^{264}$

Lastly, 1963 came and went seven years before the Second Circuit's decision in Goodis v. United Artists Television; ${ }^{265}$ back in 1963, the requirement that copyright notice be in the name of the proprietor rather than a mere licensee was still taken quite seriously. Summy-Birchard would thus have had to represent on the registration applications that it was a proprietor of the GMTA/HBTY combination both in 1935 and in 1962, a representation that it might not have been able to substantiate.

In this era of hostility toward formalities, a court might be inclined to overlook a rather gaping failure to properly register and renew the GMTA/HBTY combination. Before it does, however, it should consider that Summy-Birchard is seeking a term of copyright that would end in 2030, a full fourteen years after the term that would apply under the current Copyright Act -- life of the last surviving co-author plus 70 years -even though Patty Smith Hill, if indeed she wrote the lyrics, likely did so over 55 years before she died in 1946. Arguably, if one is seeking the sweet term of 95 years after (delayed) publication, one should have to comply with the bitter formalities.

D. Epilogue: Copyright and Ownership During the Renewal Term. Suppose that it were decided that copyright in the GMTA/HBTY combination was properly renewed in 1962-63, or that any error made in renewal could be corrected or excused. Is there anything that has happened thus far during the renewal term that affected or could affect the ownership of copyright in the song? The short answer, I think, is no. After 1944, there have been no other recorded transfers involving "Good Morning to All" or "Happy Birthday to You." The corporate transactions detailed above ${ }^{266}$ all involve the sale and purchase of the Summy-Birchard Company as a whole, so although ownership of that company has changed, its ownership of the copyright in the GMTA/HBTY combination would not have.

The only legislation that could potentially affect ownership of the extended term of copyright in the GMTA/HBTY combination would be the termination of transfer provisions in the Copyright Act of 1976. Those provisions empower authors, and certain designated successors, to terminate transfers that the authors or their successors made before Congress extended the term of copyright in 1976, and again in 1998. The provisions are complex, and I consider some of those complexities in the online Appendix on copyright ownership. ${ }^{267}$ The upshot, however, is that only Archibald Anderson Hill would conceivably have been eligible to terminate his 1939 transfer to

\footnotetext{
${ }^{263}$ See [D2].

${ }^{264}$ Recall that the Forman arrangement credited only Mildred J. Hill. Summy/Birchard may have also been trying to locate a copy of the Orem arrangement in the hope that it also credited Patty Hill, although the 1935 registration record of that arrangement, E pub 51990,credited only Mildred.

265425 F.2d 397 (2d Cir. 1970).

266 See supra p. xx.

${ }^{267}$ See [A1].
} 
Patty and Jessica (assuming that that transfer included his interest in the GMTA/HBTY combination at all); he did not exercise his termination rights before he died in 1992, and under the statute those rights were personal to him and cannot now be exercised by anyone else. Thus, assuming that the GMTA/HBTY combination remains under copyright, the ownership of that copyright has apparently remained unchanged for decades: it is owned by the Summy-Birchard Company, and possibly in part by the heirs or legatees of Louise Altenhofen, Sophia A. Smith, and Archibald Anderson Hill, although the latter have never asserted their ownership interests.

One more piece of the ownership story remains to be told. "Happy Birthday to You” generates two distinct streams of royalty income, and those streams, once separated from ownership of copyright in the song, have their own ownership history.

The first stream is the public performance income collected and distributed by ASCAP. In 1940, Mildred Hill was posthumously elected a member of ASCAP, ${ }^{268}$ probably through the efforts of Jessica Hill. Jessica and Patty likely became Mildred's successor members, entitled to whatever public performance royalties Mildred would have received as a member of ASCAP. ${ }^{269}$ Under ASCAP rules, one half of all royalties collected by the society is distributed to the composer and author members, and one half to the publisher members, regardless of the royalty split to which a composer or author and her publisher have otherwise agreed, and indeed, regardless of whether the work was composed as a work made for hire. ${ }^{270}$ When Jessica Hill died in 1951, the ASCAP composer royalties for "Happy Birthday to You" started being paid into a trust that she had set up in her will.

The other royalty stream is that which was due to the Hill Foundation under its 1944 assignment of copyright to the Clayton F. Summy Company, apparently comprising one-third of all income derived from the song other than dispensed by ASCAP. Once Jessica Hill died, the Hill Foundation became an asset of the trust that she had set up in her will - the same trust to which ASCAP royalties were to be paid. Under the terms of Jessica Hill's will, income from trust assets (which included various stocks and bonds as well the two "Happy Birthday to You" royalty streams) was to be paid to Archibald Anderson Hill during his life. Upon his death, the trust was to be terminated, and the principal was to be distributed to his surviving children, or if he didn't have any surviving

\footnotetext{
${ }^{268}$ See ASCAP Biographical Dictionary ( $4^{\text {th }}$ ed. 1980) 228 (Mildred Hill became ASCAP member in 1940). On the issue of why Patty Hill did not become a member of ASCAP, and what results that might have had for the distribution of ASCAP royalties, see $\mathrm{n}$. xx above.

${ }^{269}$ Under ASCAP rules, successor members are those who have "acquired, by will or under any law, the right, title, and interest of the member in any of his or her musical works." See Articles of Association of the American Society of Composers, Authors and Publishers, Article XX, Section 2 (available at http://www.ascap.com/reference/articles.pdf). In 1940, when Mildred Hill posthumously became an ASCAP member, Archibald Anderson Hill had transferred to Jessica and Patty Hill any interest he might have in "Good Morning to All," see [RA1], and Jessica and Patty were not thinking at the time of any interest that William Wallace Hill's successors might have had, see supra p. xx, so the application to designate successor members probably named Jessica and Patty.

${ }^{270}$ See Articles of Association of the American Society of Composers, Authors and Publishers, Article XVII, supra note xxx, section 1(c); Compendium of ASCAP Rules and Regulations, and Policies Supplemental to the Articles of Association, supra note xx, section 3.3 .
} 
children, to the Association for Childhood Education. ${ }^{271}$ Archibald Hill never had children, so when he died in 1992, the assets of the Jessica Hill trust became the property of the Association for Childhood Education, which in the meantime had added the word "International" onto the end of its name.

The Association for Childhood Education International (“ACEI”) was founded in 1892 - just at the time Mildred and Patty Hill were composing the songs for "Song Stories for the Kindergarten," as the International Kindergarten Union or IKU. ${ }^{272}$ Patty Hill was a founding member of the IKU, and was very active in the organization for many years. ${ }^{273}$ It is undoubtedly Patty Hill's involvement in the organization that led to Jessica Hill's bequest. ${ }^{274}$ Since 1994, two years after Archibald Anderson Hill's death, the ACEI has been locked in litigation with the trustee of the Jessica Hill trust, Alvin J. Burnett, over Burnett's management of the trust. ACEI charges that Burnett not only mismanaged the trust, but "misappropriated the trust assets to his own use"; it alleges that for a period of about three decades, from the 1960s through the 1980s, Archibald Anderson Hill, the income beneficiary of the trust, received a little over $\$ 7000$ from the trust, while Alvin Burnett received more than $\$ 700,000 .^{275}$ If those allegations are true, then during those three decades Alvin Burnett received far more income from "Happy Birthday to You” than any other individual.

Regardless of the outcome of that litigation, both the writer's share of the ASCAP royalties and the one-third share of the Summy/Birchard collections from "Happy Birthday to You" are now paid to ACEI. Those royalties account for over a third of the Association's total revenues, a larger portion than membership dues, ${ }^{276}$ though the ACEI does not publicize its receipt of the royalties. Given the song's ultimate origin as a kindergarten greeting, and Patty Hill's lifelong devotion to early childhood education, that use of the royalties seems appropriate. ${ }^{277}$

\section{Lessons From the History of "Happy Birthday to You"}

\footnotetext{
${ }^{271}$ See [JMH 1], pp. 3-4.

272 See http://www.acei.org/history.htm;

273 See, e.g., Ilse DeForest, "Patty Smith Hill: A Biographical Sketch By One Of Her Students," supra note xx, pp. 39-42, 59-62; http://www.kdp.org/about/laureates/laureates/pattyhill.php

${ }^{274}$ Patty Hill's own will would have set up a trust identical to that of Jessica's if Patty had survived Jessica, see [PSH 1], p.4, and the two women undoubtedly coordinated these terms.

${ }^{275}$ See [JMH 16], pp. 3-4.

${ }^{276}$ See [D3] (2003-04 Form 990 for Association for Childhood Education International, reporting \$466, 447 in income from dues, and \$583, 883 in income from royalties); [D4] (2004-05 Form 990 for Association for Childhood Education International, reporting \$457,006 in income from dues, and \$626,888 in income from royalties); [D5] (2005-06 Form 990 for Association for Childhood Education International, reporting $\$ 432,581$ in income from dues, and $\$ 738,510$ in income from royalties).

${ }^{277}$ Some of the proceeds from the sale of Summy-Birchard to Warner Communications have also been used to support early childhood education, and early childhood musical education in particular. See Bart Jackson, “Uncorking That Joyful Noise,” prepared for the March 26, 2003 edition of U.S. 1 Newspaper , available at http://www.princetoninfo.com/200303/30326p04.html.
} 
The "Happy Birthday to You" anecdote that eventually landed in Justice Breyer's Eldred $v$. Ashcroft dissent has principally been an anecdote about the excessiveness of copyright protection - an excessiveness that made it possible to protect what is essentially a folk song, somewhat modified by two kindergarten-teacher-amateurs, for over a century. The true story of the song challenges many of the assumptions on which that anecdote relies. "Good Morning to All" was not a slightly modified folk song, but an original composition on which Mildred and Patty Hill spent a great deal of effort. If, indeed, Mildred and Patty combined the "Good Morning to All" melody with the "Happy Birthday to You" lyrics around the same time the former was published in 1893, but did not authorize publication of that combination until 1935, and did not take any action against widespread unauthorized use of the song until then, then the case of "Happy Birthday to You" is an extraordinarily unusual one. Arguably, such a delay occurs so rarely that the lack of a doctrine to deal with it under the 1909 Copyright Act does not represent a major failure of copyright policy. In any event, the 1976 Act makes such a problem even less likely to occur due to its drastically reduced reliance on "publication" as a triggering event. In addition, however, there are serious questions about whether a court would find "Happy Birthday to You" to still be under copyright, due to difficulties with proving authorship of the song, with potentially improper copyright notice upon first publication, and with renewal applications that seem only to cover particular arrangements of the song rather than the song itself.

Is there anything left to be learned from this story? This Part will focus on four likely lessons. They concern the risks of relying on anecdotes in legal discourse; the difficulties of challenging copyright validity; the possible need for a doctrine of prescription in copyright law; and the need to preserve and index documentary evidence.

A. The Risks of Anecdotes. Anecdotes can have great persuasive power in law as in other areas of life, because they are engagingly concrete - what actually happened to a real, named person, or a particular song, is more engrossing, and seems more authentic, than statistics and generalizations. Yet if anecdotes are not true, or are not typical, they may give a distorted impression of the world, and may obscure the difficult policy choices that actually need to be made in a given area.

The risks of using anecdotes have been explored in a number of fields - in journalism, ${ }^{278}$ in lawyer-client relations and legal practice, ${ }^{279}$ and in narrative legal scholarship. ${ }^{280}$ The story of "Happy Birthday to You" makes it clear that an anecdote can be misleading without being false, because it can rely on triggering mistaken assumptions that are widely held by an audience. Many people likely assume that a song that they learned through performances of family and friends, in an era otherwise dominated by

\footnotetext{
${ }^{278}$ See, e.g., David Craig, The Ethics of the Story: Using Narrative Techniques Responsibly in Journalism (2006).

${ }^{279}$ See Steven J. Johansen, This is Not the Whole Truth: The Ethics of Telling Stories to Clients, 38 Ariz. St. L. J. 961 (2006); Binny Miller, Telling Stories About Cases and Clients: The Ethics of Narrative, 14 Geo. J. Legal Ethics 1 (2000); Muneer I. Ahmad, The Ethics of Narrative, 11 Am. U. J. Gender Soc. Pol'y \& L. 117, 122 (2002).

${ }^{280}$ See Daniel A. Farber \& Suzanna Sherry, Telling Stories out of School: An Essay on Legal Narratives, 45 Stan. L. Rev. 807, 809 (1993).
} 
recorded and broadcast music, is a folk song of distant, unknown origin. Thus, the teller of the anecdote need not say whether or not "Happy Birthday to You" is indeed a folk song of unknown origin. All he need say is "Can you believe that 'Happy Birthday to You' will still be under copyright?" and many audience members will react with indignation, because of their assumption that "Happy Birthday to You" is a folk song of unknown origin or is even older than it is. If a law will keep "Happy Birthday to You" under copyright, then, many audience members will assume, that law will probably also keep songs like “Auld Lang Syne” and "Yankee Doodle” under copyright, even though those latter two songs are in fact much, much older. ${ }^{281}$

Of course, the person relating an anecdote may not have any better knowledge of the story than the audience - he or she may share the same unarticulated, mistaken assumptions. That, then, is where an ethical duty may arise. A journalist, lawyer, or academic may have a duty to be mindful of the persuasive power of anecdotes; to reflect on the assumptions that lend power to the anecdote; and to consider whether further investigation is necessary to determine whether those assumptions have any basis. Investigation of such assumptions is just one part of considering whether an audience will consider that an anecdote is being offered as truthful and typical, and, if so, whether the anecdote is, in fact, truthful and typical. ${ }^{282}$ And, of course, one also needs to accept that one is never omniscient, and that the meaning of a story may be always be affected by new evidence that is uncovered. I have examined dozens of Mildred Hill's published songs and transcriptions of Negro spirituals, and none of them bore any significant resemblance to the melody used in "Good Morning to All” or "Happy Birthday to You." If another notebook turned up with a transcription a melody nearly identical to that of “Good Morning to All,” however, I would certainly have to revise my view of that song's originality.

B. Barriers to Challenging Copyright Validity. If there are such weaknesses in the alleged copyright in "Happy Birthday to You," why hasn't there been litigation resulting in a ruling on the relevant issues? ${ }^{283}$ The answer to this question may lead to

\footnotetext{
${ }^{281}$ According to James Fuld, the present melody and words of “Auld Lang Syne," both of which were separately much older, were joined by 1799; "Yankee Doodle” was well-known by the 1760s. See James J. Fuld, The Book of World-Famous Music 115, 659 (5 ${ }^{\text {th }}$ ed. 2000).

${ }^{282}$ See Farber \& Sherry, supra n. 270, at 832-840 (recommending that scholars using narratives examine them for their truthfulness and typicality).

${ }^{283}$ The weaknesses in the registration and renewal of the GMTA/HBTY combination provide a good reason why Summy-Birchard has not and would not be likely to sue for infringement itself. Any suit that it filed would be susceptible to a very early motion to dismiss based on the lack of any registration for the song (assuming that the defendant was not infringing one of the specific arrangements that have been registered, which is quite unlikely). See 17 U.S.C. §411(a) (requiring registration as a precondition of bringing an infringement action). That motion could be decided without much discovery; if it were decided adversely to Summy-Birchard, the song would be in the public domain due to the defective renewal, and the entire stream of income from the song would dry up - a very big risk to take just to enforce against one infringer. That should give some comfort at least to small-scale infringers that Summy-Birchard is unlikely to pursue them in court. Motion pictures and other large projects, however, can almost never be financed without insurance against infringement claims, and insurers are unlikely to be satisfied with an assertion that a work is almost certainly in the public domain, or that the copyright owner almost certainly will not sue. Thus, a detailed exposition of weaknesses in the copyright of "Happy Birthday to You," such as that found in this article, is unlikely to make much of a dent in the song's income.
} 
one of the principal lessons to be drawn from the history of the song. License revenues from the song have always flowed to very few parties: the Clayton F. Summy Company and its successor Summy-Birchard have always gotten at least half of the revenues, and for most of the last 70 years there has only been one other recipient of the income - either Archibald Anderson Hill under the Jessica Hill trust, or the Association for Childhood Education International. Conversely, such revenues have always flowed from many, many parties - tens of thousands of ASCAP public performance licensees, and hundreds of licensees of other rights. For litigation to go forward, a substantial number of these licensees would have to be able to combine forces, so that the potential gain from a declaration that "Happy Birthday to You" was in the public domain would be sufficient to warrant the investment in litigation. Litigation costs would be steep - Warner Music Group would no doubt mount an aggressive defense, given the stream of income at stake - and there is no guarantee that the challenge would succeed.

There are a number of barriers to assembling enough licensees to finance such litigation. ${ }^{284}$ One such barrier is the nature of ASCAP licensing. ASCAP typically issues "blanket" licenses, entitling the licensee to perform any of the more than eight million musical works in the repertory of ASCAP and affiliated foreign collecting societies. The fees charged for those licenses are not directly related to the number of musical works in the repertory at any given time - works are added to and removed from the repertory every day, without a change in fees - and thus ASCAP licensees would likely not have standing to challenge the copyright status of an individual work. ${ }^{285}$

\footnotetext{
${ }^{284}$ Patent scholars have identified a substantial barrier to challenging the validity of a patent even when there is only one licensee currently using the technology. Since the Supreme Court's decision in BlonderTongue Laboratories, Inc. v. University of Illinois Foundation, 402 U.S. 313 (1971), a ruling that the patent is invalid can be asserted as a defense against infringement, not only by the licensee that procured the ruling, but by any other party using the technology. Thus the licensee that invests in successful litigation to invalidate a patent will not get the full benefit of that invalidation, because its competitors will then have equally free access to the technology. Under those circumstances, the licensor and licensee may both benefit from a settlement that leaves an invalid patent intact - the licensee would then continue to have an advantage over its competitors, and the licensor could obtain some share of that advantage as license fees. See Joseph Scott Miller, "Building a Better Bounty: Litigation-Stage Rewards for Defeating Patents," 19 Berkeley Tech. Law J. 667 (2004); John R. Thomas, "Collusion and Collective Action in the Patent System: A Proposal for Patent Bounties,” 2001 U. Ill. L. Rev. 305.

The Blonder-Tongue case is not limited to patent law; it concerns the general issue of non-mutual defensive issue preclusion in federal courts, and would thus be equally applicable in federal copyright cases. In many copyright licensing situations, however, an exclusive license may not have such obvious competitive advantages. It is not clear, for example, that a film which features "Happy Birthday to You" in a birthday scene is going to do better at the box office than a competitor's film which also has a birthday scene but does not feature "Happy Birthday to You." In some circumstances, however, preventing competitors from using a work of authorship may well be worth a substantial amount. For instance, if a motion picture studio is contemplating making a movie version of a novel, it would likely be interested in increasing the odds against facing competition from another movie version of the same novel. Under those circumstances, the dynamic identified as a barrier to patent validity challenges could be found in copyright as well.

${ }^{285}$ Other ASCAP members would likely have standing, since their distributions are reduced by the amounts paid to the owners of "Happy Birthday to You," but it is extremely unlikely that any of them would ever bring such an action, due to norms against attacking fellow industry members on such a matter, and the real possibility of retaliation given likely vulnerabilities in a song portfolio of any size.
} 
Those licensees who purchase individual licenses from Summy-Birchard would not face a standing problem, but they would face typical collective action problems involving information costs and free riding. ${ }^{286}$ Even if most of those were solved, the number of licensees who could join together at any one time would be limited by a restrictive remedial rule, and by an identification problem. The remedial rule, well established in patent law, is that licensees who successfully challenge the validity of their licensors' intellectual property rights cannot recover or avoid paying royalties for the period before they filed their challenges. ${ }^{287}$ That rule sets the starting point for the stream of royalties that could be at issue in a lawsuit. The end point is set by an identification problem. It is likely that most licensees only become aware of their need for a license a year or less in advance, as a particular project is developed - for example, as a movie script is written that includes a birthday scene in which "Happy Birthday to You" is sung. That means that the total amount that the group of identifiable licensees and potential licensee have at stake at any one time may be only a year's worth of royalties, and that is likely not enough to make it worthwhile to finance a challenge.

Whether this is an interesting issue for copyright policy generally depends upon whether there are a substantial number of other works for which copyright license fees are currently being collected, but which would be vulnerable to challenge if barriers to litigation could be overcome. The percentage of all works currently generating revenue that are vulnerable to challenge is undoubtedly small. I think it is unlikely, however, that "Happy Birthday to You” is the only significant case.

During the 2004 Presidential campaign, the online entertainment company JibJab Media Inc. released “This Land!,” a satirical video short subject featuring animated caricatures of candidates President Bush and Senator Kerry singing Woody Guthrie's famous song “This Land is Your Land” with altered lyrics. ${ }^{288}$ Ludlow Music, Inc., the music publisher to which Guthrie assigned his rights in the song, threatened to sue JibJab

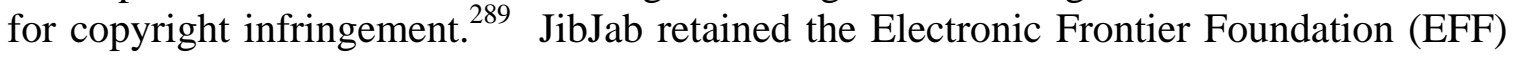
to represent it, and filed suit against Ludlow, seeking a judgment declaring that its use did

\footnotetext{
${ }^{286}$ They also might face problems of licensee estoppel. In the area of patent licensing, the Supreme Court has been quite skeptical of licensor arguments that licensees cannot challenge the validity of patents that they have agreed to license, see Lear, Inc. v. Adkins, 395 U.S. 653 (1969), and that federal courts do not have jurisdiction to hear patent validity challenges brought by licensees who continue to pay their license fees, see MedImmune, Inc. v. Genentech, Inc., 127 S. Ct. 764 (2007). With regard to copyright licensing, however, the Seventh Circuit has held that the licensee's explicit agreement not to challenge the validity of the licensed copyright is enforceable absent an antitrust violation. See Saturday Evening Post So. $v$. Rumbleseat Press, Inc., 816 F.2d 1191, 1199-1201 ( $7^{\text {th }}$ Cir. 1987) (per Posner, J.). The Rumbleseat opinion, however, also indicates that there may be stronger reasons for allowing such challenges when validity, and not just ownership, of the copyright is at issue. See id.

${ }^{287}$ See, e.g., Studiengesellschaft Kohle m.b.H. v. Shell Oil Co., 112 F. 3d 1561, 1566-1568 (Fed. Cir. 1997).

${ }^{288}$ The video is available at http://www.jibjab.com/originals/this_land.

${ }^{289}$ Ludlow's cease-and-desist letter is available at http://www.eff.org/files/filenode/JibJab_v_Ludlow/20040727_jibjabthreat.pdf. For the facts that follow relating to the Ludlow Music / JibJab Music controversy, see "JibJab Media Inc. v. Ludlow Music Inc., http://www.eff.org/cases/jibjab-media-inc-v-ludlow-music-inc, and "This Song Belongs to You and Me," by Fred von Lohmann, at http://www.eff.org/deeplinks/2004/08. I thank Rob Kasunic for telling me about this case.
} 
not infringe copyright. Ludlow claimed that it had first published the song in 1956, and that it filed a timely renewal application in 1984. Volunteers working with EFF located a copy of a pamphlet that Guthrie had published (with proper copyright notice!) in 1945. That pamphlet, entitled “Ten of Woody Guthrie's Songs” and carrying a price of 25 cents, included the song "This Land is Your Land" (under the title "This Land"), complete with music, chorus, and four verses. ${ }^{290}$ If the pamphlet really was distributed by Guthrie in 1945 -- and I have found no reason to think that it was not -- then Ludlow's renewal application was filed eleven years too late. The EFF presented that evidence to Ludlow, and Ludlow agreed to grant a license to JibJab. It did not, however, admit that copyright in the song had lapsed. ${ }^{291}$ The song is still listed in the online repertoire database of Broadcast Music, Inc., the performing rights organization to which Ludlow belongs. $^{292}$ Thus Ludlow and Guthrie's heirs or legatees are still receiving performance rights income from the song. No doubt the song still generates other licensing income as well. Of course, as this Article attempts to show with regard to "Happy Birthday to You," one should take such anecdotes with a grain of salt. Yet they at least suggest that the issue is worth investigating further. ${ }^{293}$

${ }^{290}$ A copy of the pamphlet is in the Woody Guthrie Manuscript Collection of the American Folklife Archives at the Library of Congress; a scan of that copy is available on the EFF website at [get URL].

291 One news story reported the following explanation from the attorney representing Ludlow: Ludlow's chief legal representative, Paul LiCalsi, said on Wednesday that because "This Land" was last copyrighted during a period when the song was technically considered unpublished, Ludlow's rights to the song never lapsed.

"Since there was no official publication after the last copyright, the song is still protected under the law," said LiCalsi, of the Chicago-based firm Sonnenschein, Nath \& Rosenthal.

See Evan Hansen, “JibJab Beats Copyright Rap,”(August 25, 2004), http://www.news.com/JibJab-beatscopyright-rap/2100-1026_3-5322970.html. Perhaps this explanation was misreported, because as it stands, it makes little sense. If Guthrie published the song with notice in 1945, the original term of federal copyright protection began at that time. Whether he stopped distributing the song at some point after that, or whether there was an authorized distribution after the song was first registered in 1956, should have no effect on the length of the original term of copyright, and hence on the deadline for filing a renewal application.

${ }^{292}$ Access to the database is available at http://www.bmi.com; the song is listed as BMI Work \#1502028.

${ }^{293}$ While doing research for this article, I came across a published opinion that suggests that there is yet another song that is still generating revenue but is likely no longer under copyright. In Latin American Music Company, Inc. v. Archdiocese of San Juan of the Roman Catholic and Apostolic Church, 194 F.Supp.2d 30 (D.P.R. 2001), the plaintiff charged that radio stations owned by the defendants had played without permission songs in which the plaintiff owned copyright, thus violating its public performance right in those songs. ASCAP ended up conducting the defense, because the radio stations held ASCAP licenses and ASCAP had listed these songs in its repertory, thus entitling the radio stations to ASCAP indemnification under a term in their license agreements. One of the songs clearly had not been properly renewed. The only renewal application had been filed by the music publisher. The deceased songwriter's widow and children, who owned the renewal rights, did not take any action until five years after the renewal period had passed, when they attempted to retroactively ratify the music publisher's renewal application, an action that courts have held to be ineffective. See Von Tilzer v. Jerry Vogel Music Co., 53 F.Supp. 191, 196 (S.D.N.Y. 1943) ("A renewal of a copyright by a person not entitled thereto is void and can not be cured by subsequent ratification by the person allegedly entitled to renew."); aff'd sub nom. Gumm v. Jerry Vogel Music Co., 158 F.2d 516 (2d Cir. 1946); 3 Nimmer on Copyright §9.05[D][1]. But ASCAP never raised that defense, and the song, "Ojos Chinos," remains in ASCAP's online repertory database to this day. Online access to the database is available at http://www.ascap.com/ace/; the Title Code of "Ojos Chinos" is 450075642. 
C. The Effects of Copyright Owners' Failure to Enforce. Copyright law has traditionally been extremely lenient towards copyright owners who fail to take action against infringers. Mere inaction will not result in abandonment, which requires an overt act; ${ }^{294}$ laches is an uncertain defense that requires a showing of reliance by the defendant; ${ }^{295}$ and under the 1909 Act, publication without authorization, even for a very long time, would not affect the copyright owner's opportunity to obtain federal copyright upon authorized publication. ${ }^{296}$ The Copyright Act does have a three-year civil statute of limitations, and the prevailing though not unanimous view is that copyright owners can only recover damages for those acts of infringement that have occurred within three years before commencement of an infringement suit. ${ }^{297}$ Thus, not only will an infringement suit be barred altogether if it is not commenced within three years of the last act of infringement alleged, but damages against a continuing infringer will be limited to those stemming from the last three years of infringing acts before suit was filed. Copyright law, however, has nothing like the real property doctrines of adverse possession or prescription. Under those doctrines, the failure of an owner to take timely legal action against trespass can result in the trespasser or trespassers gaining legal title to, or an easement on, the property in question.

As long as the term of federal copyright remained relatively short and was conditioned on the formality of copyright notice, there was arguably little need for such doctrines. The notice requirement meant that copyright owners would lose protection from the outset unless they posted the equivalent of a "No Trespassing" sign, with their name and an indication of when others could begin using their works (as calculated from the publication date). They then got 28 years of protection - just eight years longer than the traditional statutes of limitations on which the doctrines of adverse possession and prescription were based. At that time, the owners of renewal rights had to affirmatively indicate their interest in maintaining copyright ownership by filing a renewal application at the Copyright Office; only if they did so would they get another 28 years of protection.

To be sure, the renewal requirement is not a requirement to bring an action against infringers, but it serves some of the same functions. It requires the owner of renewal rights to identify herself; to reassert her interest in ownership; and to provide contact information. Moreover, it provides an incentive to make sure that the owner of those rights is identified correctly, since a renewal application filed by someone who does not own the rights is ineffective. Now, with a unitary term of copyright that can reach

\footnotetext{
${ }^{294}$ See supra $\mathrm{n} . \mathrm{xxx}$.

${ }^{295}$ See supra $\mathrm{n} . \mathrm{xxx}$.

${ }^{296}$ See supra $\mathrm{n} . \mathrm{xxx}$.

${ }^{297}$ See Roley v. New World Pictures, Ltd., 19 F.3d 479, 481 (9 $9^{\text {th }}$ Cir. 1994); Stone v. Williams, 970 F.2d 1043, 1049-50 (2d. Cir. 1992), cert. denied, 508 U.S. 906 (1993); Hoste v. Radio Corp. of America, 654 F.2d 11 ( $6^{\text {th }}$ Cir. 1981); but see Taylor v. Meirick, 712 F.2d 1112, 1118-1119 ( $7^{\text {th }}$ Cir. 1983) (per Posner, J.) (holding that the copyright owner can recover for all infringing acts that are part of a single course of conduct or a "continuing wrong" so long as the last of those acts took place within the limitations period). In a later decision, the Ninth Circuit modified this rule with respect to infringement that plaintiff had first discovered within the limitations period, and that a reasonable plaintiff would not have discovered earlier. Under those circumstances, the plaintiff can recover even for infringing acts occurring more than three years before it filed suit. See Polar Bear Prods. v. Timex Corp., 384 F.3d 700, 707 (9 $9^{\text {th }}$ Cir. 2004).
} 
120 years or more, copyright owners can fail to enforce their rights for generations, and then reappear and demand damages and injunctive relief, upsetting long-settled uses and expectations, and forcing courts to find facts on what may be very sparse evidence.

The copyright community has started to recognize some aspects of this problem. For example, the Copyright Office has prepared an extensive report on so-called "orphan works" -- works whose owners cannot be located after reasonable inquiry. ${ }^{298}$ The number of such works has increased greatly under the current Copyright Act, which grants copyright without formalities for a long unitary period. The Copyright Office's proposed legislation, however, does not provide for any prescriptive rights. Rather, it merely limits damages (to "reasonable compensation," with a complete bar on damages if the infringement is not performed for any direct or indirect commercial advantage (in which cases damages would unlikely be high in any event) $)^{299}$, and bars injunctive relief if the infringer has prepared a derivative work and is paying reasonable compensation. ${ }^{300}$ Unlike the doctrine of prescription, the proposed legislation does not consider whether the use has been "open and notorious," and how long it has continued without any assertion of rights on the part of the copyright owner. In fact, the proposal has a sunset provision that would make its limitations inapplicable to any infringement that occurred more than ten years after it was passed - a kind of "anti-repose" clause. Thus, the orphan works legislation is not targeted to protecting expectations that have arisen after long unopposed use, or encouraging copyright owners to take action within a fixed period of time.

The doctrines of adverse possession and prescription arose, not through legislation, but through judicial interpretation of statutes of limitations. Courts could conceivably create such a doctrine in copyright by reinterpreting the copyright statute of limitations, currently codified at 17 U.S.C. \$507(b). Instead of holding, as courts have in the past, that each infringing reproduction gives rise to a new claim and starts a new limitations clock running, courts could hold that a reasonably continuous stream of infringing reproductions (or distributions, public performances, or any other violations of exclusive rights), counts as a single act, much as real property law would treat a series of daily walks across the property of another as a single act. Courts would also have the option of treating widespread unauthorized use of a work over a long period of time in resulting in, not in private prescriptive rights, but in prescriptive rights that were held by the public at large. Most states have recognized public prescriptive easements in real property, ${ }^{301}$ and the most serious policy concern casting doubt on the recognition of such

\footnotetext{
${ }^{298}$ See Copyright Office of the United States, Report on Orphan Works (2006), available at http://www.copyright.gov/orphan/orphan-report-full.pdf.

${ }^{299}$ See id. at 127 (providing specific statutory language for a proposed new section 514(b)(1) of the Copyright Act that would limit monetary relief for orphan works)

300 See id. (providing a proposed new section 514(b)(2) that would limit injunctive relief for orphan works).

${ }^{301}$ See Restatement (Third) of Property (Servitudes) §2.18, Acquisition of Servitudes By Governmental

Bodies And The Public, Reporter's Note, Prescription and implied dedication, comment f (collecting cases form majority of states recognizing public easements by prescription).
} 
easements - governmental liability for personal injuries arising on public easements ${ }^{302}$ has no application to public use of copyrighted works, since people don't slip and fall on copyrights.

The problem is that courts will likely view the current limitations period - three years - as far too short for such an interpretation. Thus, we are unlikely to see any prescriptive rights arise though judicial action alone, and, given political realities, may be unlikely to see any legislation either. ${ }^{303}$

\section{Recordkeeping and Tracking in the Copyright Office.}

As the term of copyright gets longer, more and more disputes about ownership and validity will turn on the presence or absence of evidence about events that occurred many decades ago, and much of that evidence will itself be decades old. Some of the difficulties will not be easily resolved. When not only the authors, but their younger acquaintances and one or more generations of their descendants are no longer alive at the time a dispute arises, little relevant live testimony will be available. Some efforts to preserve documentary evidence, however, may be worthwhile.

The Copyright Office has taken commendable steps to computerize its application and recordkeeping systems, and to make portions of those systems searchable online. Due, no doubt, to budget restrictions, it has not yet attempted to digitize records that predate the computer era, which in the Copyright Office began in $1978 .{ }^{304}$ Millions of registration applications and records, and recorded transfers, are available only in the Office's enormous card catalog room, one of the most impressive collections of paper file cards on earth. But the limitations of Copyright Office recordkeeping go beyond the lack of digitization of pre-1978 records. They also include longstanding policies about the treatment of deposits, and about the retention and indexing of any registration records other than approved applications.

The Copyright Act contains two sections requiring copyright owners to deposit copies of their works. ${ }^{305}$ The first, covering all published works, is intended to build the collections of the Library of Congress. ${ }^{306}$ The second, covering all works submitted for

\footnotetext{
${ }^{302}$ See Stewart Sterk, Publicly Held Servitudes in the New Restatement, 27 Conn. L. Rev. 157, 159-161 (describing the problem of governmental obligations to maintain public easements obtained by prescription).

${ }^{303}$ Summy-Birchard itself might be interested in prescriptive rights, because it could face claims from heirs of co-owners in the copyright in "Happy Birthday to You" whose interests it never successfully acquired. Traditionally, however, prescriptive rights are very difficult to obtain against co-owners - the claimant of such rights is required affirmatively to "oust" the other co-owners to start the limitations period running. Summy-Birchard, like most other copyright co-owners, is unlikely to have "ousted" those whose interests it did not acquire.

${ }^{304}$ The Copyright Office has requested funds to digitize pre-1978 copyright records (correspondence with David Carson, Associate Register for Policy and International Affairs [check title]).

${ }^{305}$ See 17 U.S.C. §408(b) (requiring deposit upon registration); 17 U.S.C. §407 (requiring deposit upon publication). Copies submitted under $\S 407$ upon publication can also be used to satisfy the $\S 408$ (c) requirement of deposit upon registration. See 17 U.S.C. §408(b).

${ }^{306}$ See,e.g., Benjamin Kaplan, An Unhurried View of Copyright 81 n.3 (1966).
} 
registration, is intended primarily to allow examiners to determine whether the work submitted contains copyrightable subject matter. The Copyright Office offers the copies it has received as deposits under both provisions to the Library of Congress, and the Library of Congress selects those that it wants for its collection, or for the collection of the National Archives or a Federal records center. ${ }^{307}$ Those not selected are, according to statute, to "be retained by the Copyright Office . . . for the longest period considered practicable and desirable by the Register of Copyrights and the Librarian of Congress.”308 That period, however, turns out to be quite short. The Copyright Office announced in 1983 that it would only retain published materials submitted as deposits for five years, though it would try to retain visual artworks for at least ten years. ${ }^{309}$ The Copyright Act allows the submitter of the deposit to request "full-term retention," which is defined by the Copyright Office as 75 years after publication, ${ }^{310}$ a term that in many cases will fall short of the full term of copyright. If the request is granted, the depositor must currently pay $\$ 425$ for the privilege of such retention. ${ }^{311}$

Copyright deposits, however, may also be valuable evidence in determining the validity or scope of copyright protection. When, for example, the Hill Foundation claims that the version of "Good Morning to All" that was published and registered in 1907 "included" "Happy Birthday to You," 312 it would be very useful to be able to look at the deposit copy and see whether the "Happy Birthday to You" lyrics were published in that version - a fact that would have a dramatic impact on the copyright status of that song. Recall also that the Baron v. Leo Feist Co. court sanctioned examination of the deposit copy to clarify the scope of the copyright claim registered. ${ }^{313}$ Yet the availability of the deposit copy of a published work that is more than a few years old turns out to depend on whether someone in the Library of Congress decided that it should become part of the Library's collection, or whether the depositor requested and paid for longer retention.

Obviously, even the Library of Congress does not have unlimited storage capacity, and therefore a requirement that all deposit copies must be retained by the Library or the Copyright Office would not make sense. In this age of digitization, however, it is becoming much less expensive to retain copies or facsimiles of works in digital form. One can imagine a requirement that registration applicants submit digital copies or facsimiles along with physical copies, or at least an option of submitting digital copies, with the incentive of a guarantee that they would be kept permanently, even if the

\footnotetext{
30717 U.S.C. $\S 704(b)$.

${ }^{308} 17$ U.S.C. \$704(d). A deposit of an unpublished work must be kept for the entire term of copyright unless a facsimile copy of the entire work has been made part of Copyright Office records. See id.

${ }^{309}$ See 48 Fed. Reg. 12,862 (February 22, 1983). In October 1992, the Copyright Office apparently decided to retain try to deposits of published works for at least 20 years, and currently has published visual arts deposits made from 1992 onwards, and other published deposits from 1997 onwards. This policy, however, has never been formally announced, and deposits may be discarded if Congress does not provide sufficient funds for storage facilities. Correspondence with David Carson, Associate Register for Policy and International Affairs.

${ }^{310}$ See 37 C.F.R. 202.23(3).

${ }^{311}$ See 37 C.F.R. 201.3(d)(10).

312 See supra p. $\mathrm{xx}$.

${ }^{313}$ See supra p. xx.
} 
physical copies weren't. ${ }^{314}$ Congress has in fact already authorized the Copyright Office to make "facsimile reproduction[s]" of deposits, and "to make such reproduction[s] a part of the Copyright Office records of the registration[s]," before transferring the deposit copies to the Library of Congress or destroying or otherwise disposing of them. ${ }^{315}$ The recent drastic reductions in the cost of digital storage might make large-scale retention of facsimiles more financially feasible than it has been in the past.

There are other important limitations of Copyright Office recordkeeping. First, its registration processing system does not assign a publicly accessible number to each registration application. This makes it almost impossible to learn about rejected registration applications unless they have been the subject of litigation that resulted in published opinions. It also makes it very difficult to access correspondence about recent applications (one has to know that the application exists, and then pay a Copyright Office employee $\$ 150$ per hour, with a one-hour minimum, to search publicly inaccessible files). Second, the Office officially preserves correspondence relating to granted registration applications for only 30 years, and correspondence relating to rejected applications for only five years. ${ }^{316}$ In an era when no copyright can last less than 70 years, and many will last for 120 years or more, these policies mean that potentially important evidence can be discarded decades before works enter the public domain.

Compare, for example, the trademark registration system of the U.S. Patent and Trademark Office. Every application for trademark registration is immediately assigned a publicly accessible number, and soon after receipt can be searched online. All correspondence about the application, as well as notes documenting the searches done by the Trademark Examining Attorney, is digitized (or is submitted in digital form to begin with) and is also made available online. It is thus very easy to examine both rejected and approved applications, and to examine the correspondence files relating to both rejected and approved applications.

To be sure, there are far, far fewer copyright disputes than trademark disputes to which rejected applications and correspondence would be relevant, and the percentage of copyright applications that are rejected is far smaller than that of trademark applications. Moreover, while trademark law allows private parties to file opposition and cancellation actions challenging registrations, copyright law does not private parties to challenge registrations, though they certainly may challenge the validity of a copyright in litigation.

\footnotetext{
${ }^{314}$ Of course, these days, the native form of some works is digital. The Copyright Office does currently allow copyright owners to deposit digital copies if they are applying for registration online; but most published works are subject to the requirement that the "best edition" of the work be deposited, and it is the policy of the Library of Congress that the best edition of works published in hard copy is the hard copy. See 17 U.S.C. $\S \S 407(a), 408(b)$. [find LOC policy]

${ }^{315} 17$ U.S.C. $\S 704(\mathrm{c})$.

${ }^{316}$ [check 1985 Register decision on 5 yrs, and source of 30 years] According to the Copyright Office, it actually still has files relating to granted applications, known inside the office as "UBs," from 1962 onwards, and files relating to rejected applications, colloquially known as "red files," from 1997 onwards. E-mail from David O. Carson, Associate Register for Policy and International Affairs. Apparently, the cost of discarding such files is currently more than the cost of keeping them, see id., which may bode well for their longevity.
} 
Thus, one might argue, a public copyright registration tracking and recordkeeping system might not be worth the cost. The Copyright Office has, however, in the past year launched a new electronic registration system that provides improved tracking and recordkeeping internally. ${ }^{317}$ It seems unlikely that it would cost that much more to provide public access to information that is now already available internally on a networked server. ${ }^{318}$

The tyranny of anecdotes, barriers to challenging copyright validity, legal effects of a failure to enforce, Copyright Office recordkeeping -- in the end, it is difficult to draw any simple lesson from the tangled history of "Happy Birthday to You," in part because that history is still being written. Though this article must draw to a close, SummyBirchard and its parents Warner/Chappell and Warner Music Group will continue collecting about $\$ 5000$ per day in royalties on the song, and may continue to do so for more than two decades in the future, or even longer if Congress is persuaded to pass yet another retroactive extension of copyright. Only when the song enters the public domain, whether through the disappearance of any colorable claim in 2030, or through adjudication before then, will a definitive assessment of its significance be possible. In the meantime, on October $13^{\text {th }}$, the date of registration of "Song Stories for the Kindergarten" in $1893,{ }^{319}$ or December $6{ }^{\text {th }}$, the date of registration of the Forman and Orem arrangements in $1935,{ }^{320}$ we can hold a celebration -- and find an appropriate song to sing.

\footnotetext{
${ }^{317}$ E-mail from David O. Carson, Associate Register for Policy and International Affairs.

${ }^{318}$ Current regulations provide only limited access to pending registration applications. 37 CFR 201.2(b)(5). [check on apparent rationale for these limitations; also check on 201.2(b)(1)-(4)]

${ }^{319}$ See [R1].

${ }^{320}$ See [R16], [R19].
} 